University of Texas Rio Grande Valley

ScholarWorks @ UTRGV

2-16-2021

\title{
An ecotoxicological approach to microplastics on terrestrial and aquatic organisms: A systematic review in assessment, monitoring and biological impact
}

Omar A. Vazquez

The University of Texas Rio Grande Valley

Saydur Rahman

The University of Texas Rio Grande Valley

Follow this and additional works at: https://scholarworks.utrgv.edu/bio_fac

Part of the Biology Commons

\begin{abstract}
Recommended Citation
Vazquez OA, Rahman S, An ecotoxicological approach to microplastics on terrestrial and aquatic organisms: A systematic review in assessment, monitoring and biological impact, Environmental Toxicology and Pharmacology (2021), doi: https://doi.org/10.1016/j.etap.2021.103615
\end{abstract}

This Article is brought to you for free and open access by the College of Sciences at ScholarWorks @ UTRGV. It has been accepted for inclusion in Biology Faculty Publications and Presentations by an authorized administrator of ScholarWorks@ UTRGV. For more information, please contact justin.white@utrgv.edu, william.flores01@utrgv.edu. 
Classification: Review article

An ecotoxicological approach to microplastics on terrestrial and aquatic organisms: A systematic review in assessment, monitoring and biological impact

Short title: Impact of microplastics on terrestrial and aquatic organisms

Omar A. Vázqueza, and Md Saydur Rahmana,b,*

aBiochemistry and Molecular Biology Program, University of Texas Rio Grande Valley, Brownsville, Texas, USA

bSchool of Earth, Environmental, and Marine Sciences, University of Texas Rio Grande Valley, Brownsville, Texas, USA

Manuscript information: Abstract 150 words, 2 figures, 2 tables, and 2 supplementary tables

*Correspondence: MD Saydur Rahman, Ph.D., School of Earth, Environmental, and Marine Sciences, University of Texas Rio Grande Valley, 1 West University Drive, Brownsville, Texas 78520, USA. Tel: 1-956-882-5041, Fax: 1-956-882-5043, E-mail: md.rahman@utrgv.edu 
Highlights

- Microplastics distribute from primary and secondary sources in the environment.

- Plastic debris biodegrade at nanoscale through fragmentation, heat, and chemical stress.

- $\quad$ BDE-47 desorbs from microplastics to the environment and aquatic organisms.

- Exposure to plasticizers exacerbate the onset of human diseases (e.g., cancer).

- Aquatic organisms reflect the physiological disruption of microplastics.

\begin{abstract}
Marine and land plastic debris biodegrades at micro- and nanoscales through progressive fragmentation. Oceanographic model studies confirm the presence of up to 2.41 million tons of microplastics across the Atlantic, Pacific, and Indian subtropical gyres. Microplastics distribute from primary (e.g., exfoliating cleansers) and secondary (e.g., chemical deterioration) sources in the environment. This anthropogenic phenomenon poses a threat to the flora and fauna of terrestrial and aquatic ecosystems as ingestion and entanglement cases increase over time. This review focuses on the impact of microplastics across taxa at suggested environmentally relevant concentrations, and advances the groundwork for future ecotoxicological-based research on microplastics including the main points: (i) adhesion of chemical pollutants (e.g., PCBs); (ii) biological effects (e.g., bioaccumulation, biomagnification, biotransportation) in terrestrial and aquatic organisms; (iii) physico-chemical properties (e.g., polybrominated diphenyl ethers) and biodegradation pathways in the environment (e.g., chemical stress, heat stress); and (iv) an ecotoxicological prospect for optimized impact assessments.
\end{abstract}

Abbreviations: PCBs, polychlorinated biphenyls; PAHs, polycyclic aromatic hydrocarbons; PBDEs, polybrominated diphenyl ethers; POPs, persistent organic pollutants; HOCs, hydrophobic organic chemicals; HACs, halogenated aromatic compounds; GESAMP, group of experts on the scientific aspects of marine environmental protection; GPGP, Great Pacific Garbage Patch; PET, polyethylene terephthalate; PVC, polyvinyl chloride; LDPE, low-density polyethylene; PBDPOs, polybrominated diphenyl oxides; WHO, World Health Organization; BFRs, brominated flame retardants; EDPs, environmentally degradable polymers; PP, polypropylene; PE, polyethylene; PS, polystyrene; mFTIR, 
micro-Fourier transform infrared spectroscopy; fCARS, fluorescent-coherent anti-Stokes Raman scattering; BDE-47, polybrominated diphenyl ether 47; NPSG, North Pacific Subtropical Gyre; DDT, dichlorodiphenyltrichloroethane; DDE, dichlorodiphenyldichloroethylene; GADD45A, DNA-damageinducible protein; $B A X A, B C L 2$ associated $\mathrm{X}$ protein a; $C A S P 2$, caspase2 apoptosis-related cysteine protease; CASP3A, caspase3A apoptosis-related cysteine protease; CASP9, caspase9 apoptosis-related cysteine protease; PRKAR2AA, protein kinase cAMP-dependent type II regulatory subunit alpha; BIRC2, baculoviral IAP repeat containing 2; DFFB, DNA fragmentation factor; BIRC7, baculoviral IAP repeat containing 7; NFKBIAB, nuclear factor of kappa light polypeptide gene enhancer in B-cells inhibitor, alpha b; BCL2L1, blc2-like 1; MYD88, myeloid differentiation primary response 88; TRAF3, TNF receptor associated factor 3; CCT3, T-complex protein 1 subunit gamma; CRADD, death domain-containing protein; MCL1B, protease myeloid cell leukemia sequence 1b; TRAF6, TNF receptor-associated factor 6

Keywords: microplastics, biodegradation, bioaccumulation, 


\section{Table of Contents}

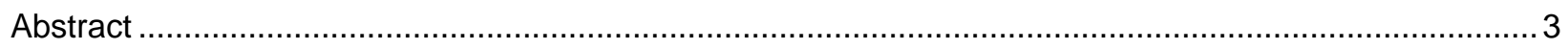

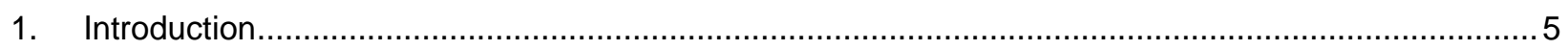

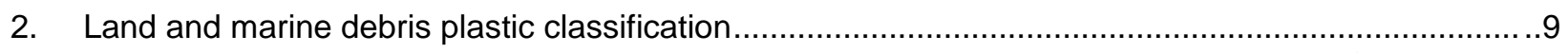

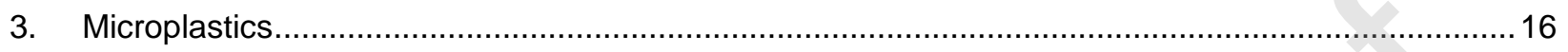

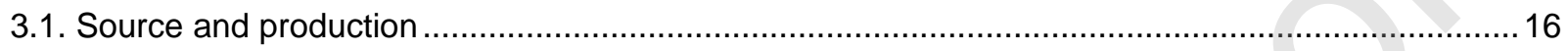

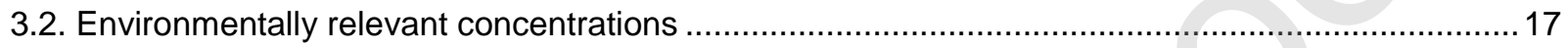

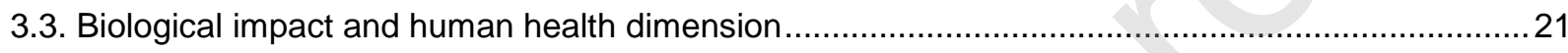

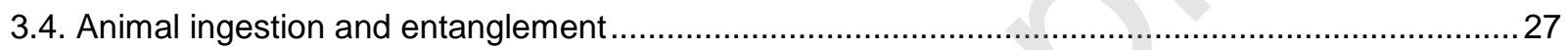

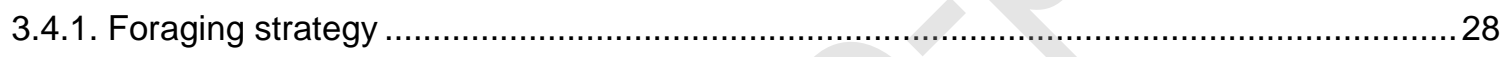

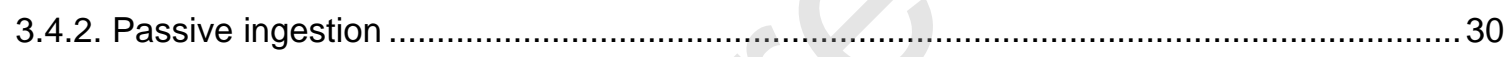

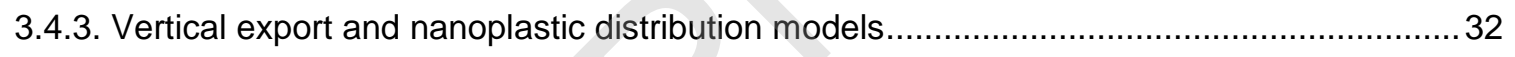

4. Methods for microplastic monitoring and impact assessment ................................................ 34

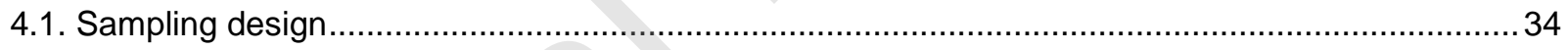

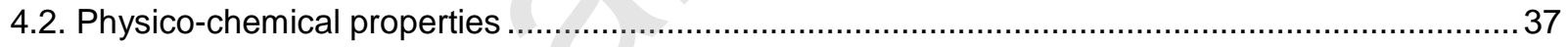

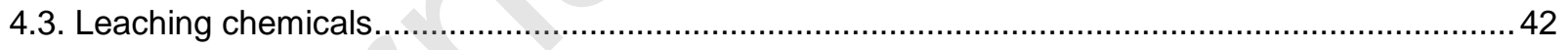

5. Ecotoxicological prospect: optimized impact assessment ................................................... 45

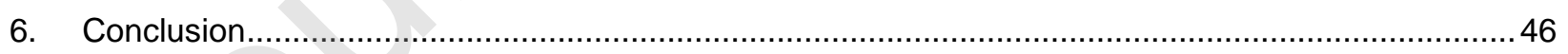

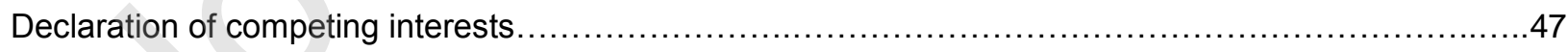

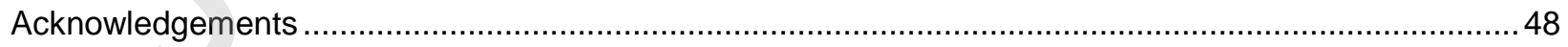

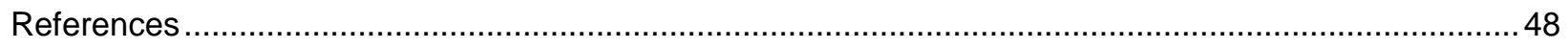

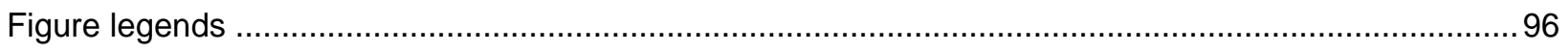




\section{Introduction}

It was first reported in the 1970 s that marine plastic debris was an environmental concern (Carpenter and Smith, 1972; Colton et al., 1974). Nonetheless, the production of plastics (e.g., food packaging, construction material, medical/agricultural equipment, etc.) has dominated the manufacturing industry since the 1950s (UN Environment, 2018). In 1972, the United Nations Environment Assembly acknowledged the dissemination of plastic waste as a threat to marine life, including projections of collateral damage up to $\$ 13$ billion a year (Wang et al., 2016). However, it was not until 2014 that the assembly made a consensus of the resolutions that led to a global policy-making governance structure on the matter of marine plastic debris (Sharma and Chatterjee, 2017; Garcia et al., 2019; Hartmann et al., 2020). Policy-relevant concerns that scientists at the Joint Group of Experts on the Scientific Aspects of Marine Environmental Protection (GESAMP) have asserted regarding debris in marine and surrounding ecosystems (i.e., coastal, freshwater, terrestrial) include: (1) impact on biota, (2) impact on human health and well-being, (3) impact on the ecosystem, and (4) overall indicator of ecosystem contamination (GESAMP, 2019). In 2018, plastic pollution in the oceans was acknowledged as an issue of the international agenda during the $45^{\text {th }} \mathrm{G} 7$ summit (Garcia et al., 2019). International recognition of microand nano-plastics increased gradually from 2011-2019 as several scientists tried to reach a consensus on definitions of size in accordance with the European Commission. This included characterization of particles or fragments $<1 \mathrm{~mm}$ as "microplastics," whereas "true nanoplastics" between 1-100 nm with a "nanoplastics" subdivision in the range of 100-1000 nm (European Commission, 2011; Wagner et al., 2014; Bergmann et al., 2015; da Costa et al., 2016; Hartmann et al., 2019). However, these classifications do not address aspects of microplastics such as their physico-chemical properties, the main biochemical pathways affecting their degradation, or their fate and impact in water and soil (Wang et al., 2016).

Since the 1970s, the North Atlantic and North Pacific oceans have been subject to expeditions with the purpose of mapping zones of macro- and micro-plastic accumulation, of both sea- and landbased sources, that has accumulated in the subtropical gyres (Lebreton et al., 2012; Eriksen et al., 
2013a,b; van Sebille et al., 2015). Additionally, data from 2001-2012 oceanographic numerical models determined that the North Pacific subtropical gyre remained the major microplastic accumulation zone ( 1,000,000 particles $\left./ \mathrm{km}^{2}\right)$ (Lavender et al., 2014). Thus far, the observations of continuing expeditions and water column monitoring (i.e., surface waters, sea floors, coastal areas, river bottoms) across seas have demonstrated a tendency of anthropogenic microplastics to accumulate primarily in coastal areas as opposed to offshore regions (Barnes et al., 2009; Ribic et al., 2010; Doyle et al., 2011; Collignon et al., 2012; Dubaish and Liebezeit, 2013). In order of greatest to least plastic debris load, these areas include the: North Pacific Central Gyre $\left(334,271\right.$ items $\left./ \mathrm{km}^{2}\right)$, Laurentian Great Lakes in the United States $(43,000$ items $\left./ \mathrm{km}^{2}\right)$, South Pacific Ocean $\left(26,898\right.$ items $\left./ \mathrm{km}^{2}\right)$, Geoje Island in South Korea $\left(16,000 \mathrm{items} / \mathrm{m}^{3}\right)$, North East Pacific Ocean $\left(9,180\right.$ items $\left./ \mathrm{m}^{3}\right)$, and the waters around Australia $\left(4,256.4\right.$ items/ $\left.\mathrm{km}^{2}\right)($ Moore et al., 2001; Reisser et al., 2013; Eriksen et al., 2013a,b; Desforges et al., 2014; Song et al., 2014; Song et al., 2015).

Projections to year 2050 reveal the need for reduction and removal strategies to help decrease the amount of secondary microplastic emitted into the ocean from terrestrial environments (Lebreton et al., 2019). Furthermore, because of poor terrestrial waste mismanagement, the number of microplastics that interact with reef-building corals and microhabitats is estimated to increase $40 \%$ by 2025 , and thus, severely affect fisheries. (Lamb et al., 2018). Aside from the fact that plastic litter has become the substrata for sessile organisms (i.e., mollusks, bryozoans, cnidarians, polychaetes), and therefore has enhanced some community structures, assemblage and ecological function of these systems at the sea surface and sedimentary soft-bottoms (Katsanevakis et al., 2007; Kiessling et al., 2015; Gündoğdu et al., 2017); many cases of entanglement with large plastics have been reported on ecosystem engineers (i.e., macrophytes, bivalve/sponge beds) as well as 418 coral reef species (de Carvalho-Souza et al., 2018). Of the factors that have led to the extensive impact of marine pollution globally, corporate-induced consumer behavior and mismanagement of product end-of-life are the most detrimental (Alimba and Faggio, 2019; Garcia et al., 2019; Fadare et al., 2020). Examples of consumer behavior are reflected in the abundance of microplastics (i.e., polyethylene granules, polypropylene granules, polystyrene spheres) in the environment that are derived from industrial and domestic products, such as air blasting media, 
facial cleansers, cosmetics, and medicine and drug vectors (Zitko and Hanlon, 1991; Betts, 2008; Moore, 2008; Patel et al., 2009).

Plastic waste management in land and water bodies has been a governmental issue as much in the US (i.e., North Atlantic gyre) as in the Asia-Pacific (i.e., North Pacific gyre) region. Fibers are the most common form of microplastics in sediments from the Atlantic to Indian Ocean (Woodall et al., 2014). It has been suggested that rivers in Asia (e.g., Bangladesh, China, India, Indonesia, Philippines) are the primary source of plastic waste emitted into the Pacific Ocean, with an estimated 2.41 million tons discharged between May and October annually (Lebreton et al., 2017; Garcia et al., 2019). The plastic island located in the subtropical region between Hawaii and California, the Great Pacific Garbage Patch (GPGP) within the North Pacific Subtropical Gyre (NPSG), harbors close to 80,000 tons of floating plastics including fishing nets and microplastic particles (Lebreton et al., 2018). Humans are exposed to microplastics and the chemicals associated with them through seafood consumption (e.g., fish, shellfish) (Rochman et al., 2016). The phenomena known as bioaccumulation and biomagnification occur as contaminated phytoplankton (i.e., cyanobacteria, flagellates, diatoms), zooplankton (i.e., copepods, cnidaria) and other invertebrates such as detritivores (e.g., Arenicola marina, a large marine worm) from planktonic and benthic ecological niches are the primary feed of fish (e.g., cod, mackerel, herring, shark, tuna, etc.) and shellfish (e.g., bivalves, crustaceans) that are destined for human consumption (Li et al., 2008; Foekema et al., 2013; Wright et al., 2013; Cole et al., 2015a; Long et al., 2015; Romeo et al., 2015; Bråte et al., 2016; Rummel et al., 2016; Taylor et al., 2016; Welden and Cowie, 2016).

According to the 1996 Plastics Task Force Report convened by the Ecology Center in Berkeley, human health is at risk due to the direct biological impact of the most commonly found types of plastic in the environment and daily use which include polyethylene terephthalate (PET; e.g., carbonated drinks bottles, peanut butter jars, microwave packaging), PE (e.g., supermarket bags, plastic bottles), polyvinyl chloride (PVC; e.g., plumbing pipes and guttering, shower curtains, window frames, flooring, films), and low-density polyethylene (LDPE; e.g., outdoor furniture, siding, floor tiles, shower curtains, clamshell packaging, films) (Ecology Center, 1996). Among the direct health effects associated with exposure to these plastics are the potential presence of human carcinogens, structural changes of cells due to estrogenic chemical release, cancer, birth defects, genetic changes, chronic bronchitis, ulcers, skin 
disease, deafness, vision failure, indigestion, and liver dysfunction (Table 2, Halden, 2010; Ghosh et al., 2013; Singh and Balla, 2017; Chang et al., 2020; Du et al., 2020). As per the European Parliament Council, different hazard levels have been established according to the impact of different plastic materials to humans, aquatic life, and the environment: very low (e.g., flammable), low (e.g., respiratory and skin irritation, eye damage), medium (e.g., toxicity, suspected of carcinogenicity, suspected of damaging fertility), high (e.g., fatal if inhaled, suspected of germ cell mutagenicity, damage to organs), and very high (e.g., carcinogenicity, germ cell mutagenicity, damage fertility) (European Parliament Council, 2008; Lithner et al., 2011). In terrestrial and marine organisms, ingestion of microplastics and associated toxicants result in a decrease in steroid hormone levels, delay ovulation, and lead to reproduction failure (Azzarello and Vleet, 1987; McCauley and Bjorndal, 1999; Wright et al., 2013b). Reported systemic effects of microplastics in marine organisms include decreased immune response and function, the production of oxidative stress, changes at the cellular and sub-cellular levels, and altered neuromodulatory functions (Guzzetti et al., 2018; Franzellitti et al., 2019). These physiological effects at the neuroendocrine level in adult Oryzias latipes include the downregulation of choriogenin $(\mathrm{ChgH})$ in males, and the downregulation of vitellogenin and estrogen receptor (ERa) in females, which hampers the apical points of growth and reproductive success depending on timing and developmental stage of exposure (Rochman et al., 2014a). Moreover, the ubiquity of microplastics in all ecosystems (i.e., terrestrial, freshwater, coastal, marine) due to their association and biological re-activation with organisms and already existent contaminants such as PCBs, polycyclic aromatic hydrocarbons (PAHs), polybrominated diphenyl ethers (PBDEs), and dichlorodiphenyltrichloroethanes (DDTs) (Hirai et al., 2011; Wagner et al., 2014; D’Alesaandro et al., 2018; Barletta et al., 2019; Strungaru et al., 2019).

As humans, terrestrial, and marine fauna are exposed to and ingest bioaccumulated and resuspended plastic remnants, respectively, their physiology can be hampered and result in chronic and or lethal consequences, with evidence of significantly minimized survival rates for aquatic organisms (Rist et al., 2016; Guzzetti et al., 2018). Scientists have demonstrated that metric tons of anthropogenic microplastic emissions accumulate in the ocean surface every year, and these degrade into nanoplastics as they sink to deep-sea sediments (Lebreton et al., 2019). Microplastics undergo dynamic interactions at coastal environments and thus are deposited in land as part of a positive feedback loop mechanism that 
takes decades (Lebreton et al., 2019). Aside from the plastic debris scattered on land by densely populated and industrialized areas, an alternate feedback of microplastics from land to aquatic ecosystems resides in domestic wastewater treatment processes (i.e., anaerobic digestion, thermal drying, lime stabilization), including landfills, stormwater and refuse site leachate (Browne et al., 2010; Mahon et al., 2017; Raju et al., 2018; Hu et al., 2019). Plastic progressively fragmentates (i.e., shredding, flaking) in lime stabilization samples, thus the population of the small size class particles that infiltrate into the ocean through the flow path of freshwater aquifers is augmented by the aquafer itself (Healy et al., 2016). The progressive fragmentation of plastics occurs more often at beaches, as both chemical (i.e., UV photodegradation, high oxygen availability) and mechanical weathering (i.e., abrasion, wave action, turbulence) facilitate the process by oxidizing matrix polymers and causing loss of structural integrity (Browne et al., 2007; Barnes et al., 2009; Corcoran et al., 2009).

The main anthropogenic and environmental factors that are accounted for in global mitigation strategies are waste management, quantification, size classes and densities of litter, spatial variability (e.g., particle abundance) and temporal and hydrological data (e.g., tidal conditions, wind and rain events, water depth, bottom topography, surface and near-bottom currents) as well as factors affecting particle buoyancy (e.g., material density, air entrapment, biofouling) (Andrady, 2015; Kooi et al., 2017; Lebreton et al., 2017; GESAMP, 2019). Analysis of sub-surface seawater microplastic samples (i.e., 75\% fibers) from the northeastern Pacific Ocean and coastal British Columbia revealed a concentration of 8-9,200 particles $/ \mathrm{m}^{3}$ that fluctuates depending on oceanographic factors (Desforges et al., 2014). A multi-scale spatial study of the GPGP averaged a median microplastic concentration of $\sim 0.021-0.44$ particles $/ \mathrm{m}^{2}$ with a cross-sectional area of $0.01 \mathrm{~cm}^{2}$ in the sea surface at low-wind conditions (Goldstein et al., 2013). In California, it was reported that the abundance of microplastics was augmented 6 -fold $\left(10-60\right.$ particles $\left./ \mathrm{m}^{3}\right)$ as a storm event increased the water volume in a river, and thus, the translocation of plastic litter far from the estuary (Moore et al., 2002). Furthermore, discarded fishing gear that ends up in the ocean amounts to $\sim 640,000$ tons, which represents $10 \%$ of the total plastic marine debris (Good et al., 2010). The combination of coastal recreational activities, manufacturing, accidental spillage, solid waste disposal, wastewater treatment works, environmental factors, topography-based hydrological models and extreme weather conditions (e.g., hurricanes, flooding) exacerbate the transition of land-based plastic debris to 
water bodies and vice-versa (Redford et al., 1997; Barnes et al., 2009; Browne et al., 2010; Cole et al., 2011; Lee et al., 2013; Birch et al., 2020).

Among the strategies and solutions targeted to societal behavior for decreasing marine litter include education, circular economy, politics, and the implementation of plastic-based fashion, furniture, and clothing (Williams and Rangel-Buitrago, 2019). However, the identification of land and marine plastic debris is the first and foremost recommended strategy in plastic waste removal, followed by its quantification as per ecological niche, and the determination of environmentally relevant concentrations for inhabiting species. Nevertheless, data regarding the biochemical degradation of different plastic compounds are still insufficient for the transition from risk assessment-based studies to an ecosystemic impact assessment approach that is relevant in the optimization of biomonitoring strategy design and the development of distribution models with predictable patterns. The aim of this review paper is to elucidate the classification of the most abundant types of plastic common to all ecosystems, their biological impact on human health, terrestrial and aquatic organisms, as well as proposed methods for the identification of the physical and chemical properties of plastics and their ecotoxicological potential.

\section{Land and marine plastic debris classification}

The distribution of microplastics is affected according to their sources, which are defined as primary (e.g., exfoliating cleansers, body washes, toothpastes, cosmetics, packed bed of air-blasting scrubbers, post-industrial manufacturing plastic scrap) and secondary (e.g., as a result of chemical and biological deterioration in the environment) (Fendall and Sewell, 2009; Browne et al., 2011; McCormick et al., 2014; Wang et al., 2016). The microbeads that form most cosmetics are decomposed into smaller fragments and pellets end up in the US municipal wastewater effluents with an estimated rate of $\sim 23$ billion microplastic particles per day (Mason et al., 2016). In addition, the production of carpets, washing of synthetic clothing, and use of ion exchange mediums in water purification/softening processes and the healthcare industry contribute to the dispersal of fibrous microplastics and polystyrene resin beads (de Dardel and Arden, 2008; Browne et al., 2011; Dardel, 2016). As a result, the US banned the manufacture of microbeads used in cosmetics under the 2015 Microbead-Free Water Act (Ballent et al., 2016). In furtherance of these issues, studies have identified $<2 \mathrm{~mm}$ opaque fragments derived from vehicle tires at 
the subsurface of European and North Atlantic subtropical seawaters, which originated as shredded crumb rubber during used tire recycling processes as per the 1990 Environmental Protection Act, Revised Statute of Ontario -Regulation 347: General Waste Management (Hopewell et al., 2009; Ballent et al., 2015; Lenz et al., 2015). However, plastics are currently not a regulated constituent under this act, and therefore pose a threat to water bodies such as Lake Ontario which is surrounded by manufacturing facilities. Sites such as this are analogous to the wastewaters near industrial point sources in Austria (100 $\mathrm{L} / \mathrm{s}$ flow rate at Danube river) that have been shown to allow a $30 \mathrm{mg} / \mathrm{L}$ plastic load with a potential to accumulate 95 tons per year (Lechner and Ramler, 2015). Negligence on the recirculation of microplastics in the marine environment has been attenuated in some parts of the globe whereas not in others. Furthermore, there is growing evidence of plastic ingestion by aquatic organisms and bioaccumulation in higher-trophic levels which potentiate biomagnification to humans (Wang et al., 2016; Munno, 2017).

Most of the plastic debris that has been introduced anthropogenically since the 1920 s and which can be found in most ecosystems is classified into two categories: polybrominated diphenyl ethers (PBDEs) and low-density polyethylene (LDPEs) (Hardy, 1999; Darnerud et al., 2001). It was first reported in 1993 that the European Union's Existing Chemicals Regulation began a systematic review on two polybrominated diphenyl oxides (PBDPOs), a decabromodiphenyl oxide (DBDPO) and an octobromodiphenyl oxide (OBDPO), to assess their toxicological and environmental effects. This study indicated that the plastic processing industry had minimal production processes of polybrominated biphenyls (PBBs), PBDPOs and Tetrabromobisphenol A (TBBPA). They also suggested they can be adequately controlled, and their transportation and storage minimized to avoid spillage accidents (Hardy, 1999). Similarly, the following year, the World Health Organization (WHO) assessed the health and environmental effects, as well as potential risks, of existing chemicals among which PBDPOs were included (WHO, 1994). PBDEs, also known as brominated flame retardants (BFRs) as per their function, were registered in the Organisation for Economic Co-operation and Development risk reduction program as part of a US chemical regulatory policy in 1995 (Hardy, 1999; Lassen et al., 1999). The importance of classifying plastic waste with BFR properties is to identify potential biochemical impacts (i.e., toxicitybased high and low doses, bioavailability, water solubility, half-life inside organisms, photodegradation) in 
different ecosystems as well as the species that inhabit them, including humans, so as to develop the scientific basis of environmental monitoring programs and assess the extent of bioaccumulation of these chemicals (Hardy, 1999). For example, DBDPOs have been determined to not be acutely toxic to mammalian or aquatic species.

The toxicological properties of DBDPO elucidate that this toxicant does not affect reproduction or produce chronic or long-term toxicity due to associated factors (e.g., poor absorption, rapid elimination, metabolization). The primary use of DBDPO is as a thermoplastic, thus, reducing its diffusion as an environmental contaminant (i.e., release, exposure) and its bioavailability is limited to sediment-dwelling species as plastics bind to sediments which reduce their bioaccumulation risk (WHO, 1994). Studies that have performed pharmacokinetics, as per the National Toxicology Program (NTP) report, determined that DBDPOs have a half-life of $<24$ hours when exposed to rats (NTP, 1975, 1986). Similarly, two DBDPOs (i.e., octabromodiphenyl, tetrachlorobiphenyl) were shown not to bioconcentrate in fish (Norris et al., 1974). Based on the chemical structure of PBDPOs, DBDPOs are not able to adopt a coplanar conformation as the steric hindrance of ether linkages in biphenyl molecules impose a high barrier of rotation. Additionally, all the brominated ortho positions (e.g., 2,2',6,6') commit the phenyl rings into an orthogonal conformation that inhibits their association with PCB or PBB congeners, and dioxin-like toxicity (Hardy, 1999). Although DBDPOs, along with pentabromodiphenyl oxides (PeBDPOs) and hexabromocyclodecanes (HBCDs), were considered still in use during 1999, the contamination of groundwater by waste BFR plastics was negligible due to their high adsorption into soil/sediment (Hardy, 1999).

Efforts towards the development of environmentally degradable polymers (EDPs) started in the 1980 s as the global plastic waste problem was exacerbated with an exaggerated production of plastics (Selke, 1996; Scott, 1999). As such, these degradable materials were designed to be compatible with $\mathrm{CO}_{2}, \mathrm{H}_{2} \mathrm{O}$, and cell biomass (Scott and Gilead, 1995). Since the 1990 s, newly synthesized plastic products needed to be certified as EDPs by standardization bodies, determined by the evaluation of a variety of environmental degradation criteria such as physical (i.e., thermal oxidation, radiative oxidation), chemical (i.e., solvolysis, hydrolysis, bio-promoted mineralization) and mechanical (i.e., shear, compression) (Doi and Fukuda, 1994; Vert et al., 1994; Sawada, 1998; Avella et al., 2001). However, 
EDPs have not been successful as their commercialization has to be targeted to the agricultural sector (i.e., mulch films), gastronomy (i.e., foam-like food), packaging (i.e., beverage containers, kitchenware, shopping bags) and other factors affecting manufacturing processes (e.g., high production cost, R\&D investments, lack of market) as well as social perspectives (e.g., environmental materials policy incentives, public awareness) (Krzan et al., 2006). Among the compounds that are being developed or are already used as EDPs are aliphatic polyesters (i.e., poly[glycolic acid]), PGA - resembling albumin), poly(ethylene terephthalate) modified copolyesters (i.e., Ecoflex, EastarBio - resembling heparin), poly(vinyl alcohol) (i.e., resembling chitin/chitosan), polyamides (i.e., copolyamides - resembling cellulose and derivatives), poly( $\beta$-hydroxy alkanoate) (i.e., PHA - resembling dextran), and pseudopoly( $\alpha$-amino acids) (i.e., poly - resembling pectin, Table 1) (Krzan et al., 2006).

The plastic debris in the marine environment as well as in terrestrial ecosystems has stimulated the development of research in the fields of polymer science and environmental engineering (Wang et al., 2016; Law, 2017). In particular, the ubiquity, persistence, and routes of plastics in marine ecosystems have been the motive for imperative qualification tests and quantification at different biological niches as well as the examination of their ecological and economic impacts (Law, 2017). In the context of EDPs, the American Society for Testing and Materials (ASTM) standardized biodegradability and composability tests in 1999. Moreover, the International Organization for Standardization (ISO) also contributed to this issue from 1992-1997 on both biodegradation in soil and in aqueous media (Vert et al., 1994; Sawada, 1998).

Efforts in the establishment of certifications and standardizations is valuable as the classification of land and marine plastic debris in developing countries is imperative for further development of plastic waste monitoring, management, and removal programs. On the matter of institutional capacity, technology, and the founding of EDP laboratories for training, testing, and pilot projects, the International Centre for Science and High Technology - United Nations Industrial Development Organization (ICSUNIDO) has been promoting awareness and global action (Hemjinda et al., 2005). For example, one pilot project categorized and quantified microplastics $<4.75 \mathrm{~mm}$ in diameter across 29 Great Lake tributaries throughout the US based on their morphology as follows: fibers/lines (i.e., fishing line, nets, synthetic textiles), pellets/beads (i.e., pre-production pellets, personal care microbeads, bead blasting, spheroids), foams (i.e., cups, food containers), films (i.e., bags, wrappers), and fragments (i.e., plant-based plastic 
bottles) (Baldwin et al., 2017). A positive correlation was found in these 29 tributaries between the categories of pellets/beads, foams, films and fragments, and the runoff of water-shed attributes in urban areas, whereas fibers negatively correlated to wastewater effluents and hydrologic conditions (Baldwin et al., 2016). These reports are similar to as observed in several estuarine rivers of the Chesapeake Bay. Furthermore, the daily amount of synthetic fibers ( $\mathrm{m}^{2} /$ day) settled in streams or landscapes through atmospheric deposition was twice as high in the urban areas of Paris compared to suburban ones (Dris et al., 2016). Of note, it is imperative that monitoring programs to be able to identify potential non-plastic sources of fibers, such as cellulose-based materials and naturally occurring biological exudates found in the digestive tract of invertebrates (Remy et al., 2015; Carr et al., 2016).

A different long-term field study identified virgin PS debris (i.e., PS pre-production pellets from the manufacturing industry) as a vector for the sorption and sinking of PAHs (organic combustion-derived contaminants known for their ubiquity, bioaccumulation and toxicity), in particular the congener 2methylanthracene (Harvey, 1998; Zabaniotou and Kassidi, 2003; Horii et al., 2008; Ma et al., 2009; Rochman et al., 2013a, b). Among the 25 PAHs identified (i.e., $925.6 \mathrm{ng} / \mathrm{g}$ ) in the work of Rochman et al. (2013a), these include low-molecular weight parent PAHs from petrogenic sources (i.e., acenaphthene, acenapthylene, anthracene, fluoranthene, fluorene, phenanthrene, pyrene), alkyl-PAHs as byproducts of petroleum emissions (i.e., 1,3-dimethylnaphthalene, 2,6-dimethylnaphthalene, 1-methylphenanthrene, 2methylphenanthrene), oxy-PAHs from organic combustion (i.e., 9-fluorenone, 1,4-naphthoquinone) and an alkyl substitute derivative from oil products such as gasoline or diesel (i.e., dibenzothiophene) (Dickhut et al., 2000; Soclo et al., 2000; Sienra, 2006). Interestingly, as PAHs adhere to plastic debris in aquatic habitats due to their hydrophobicity, the concentration of PAHs on virgin PS debris were similar to those of the two most mass-produced polymers: high-density polyethylenes (HDPEs) and LDPEs vectors. Moreover, they were higher than levels found on PPs, PET, and PVC (Dmitrienko et al., 2001; Hirai et al., 2011; PlasticsEurope, 2012; Rochman et al., 2013; Lohmann, 2015). In Southern Ontario, Canada, plastic compounds such as the polycarbonate (PC) used to manufacture CD-ROM discs as well as polyurethane (PU) foams in furniture and adhesives (i.e., construction glue, surface coating, sealing applications) consist of derivatives that are considered hazardous (Lithner et al., 2009; Ballent et al., 2016). Plastics with BFRs, bisphenol-A plasticizers, phthalates, nonylphenol or added antimicrobials are 
able to self-modify their physical properties, are associated with cancer and known to be detrimental to the endocrine system of a variety of organisms (i.e., invertebrates, fish, amphibians) (Browne et al., 2007; Oehlmann et al., 2009; Teuten et al., 2009; Lithner et al., 2011; Brander, 2013; Rochman et al., 2014b). Furthermore, a total of $\sim 3,500$ kilotons of PE ( $80 \%$ as synthetic resin/rubber), PS, PVC, PET among other plastic compounds (i.e., ethylene vinyl acetate, polyacrylamides, nylons, latex emulsions, polyesters, silicones, butyl/halobutyl rubbers) were produced in 2014 according to the Canadian Chemical Industry (Ballent et al., 2016). Similarly, a study on the quantification of microplastics in Lake Ontario, Humber Bay and Toronto Harbour was able to identify additional plastic compounds in different amounts: PE (31\%), PS (10\%), PU (4\%) and PP/PVC/polystyrene sulfonate (PSS) (3\%) among others (i.e., PET, polymethyl methacrylate [PMMA], polyvinyl/vinyl acetate copolymer, PMMA-PS copolymer-including mixture, acrylonitrile butadiene styrene [ABS], nylon, phenoxy/epoxy resin, polymethylsiloxane [silicone]) (Table 1, Ballent et al., 2016). Efforts on the classification of these types of microplastics have allowed the description of their common behavior in water bodies and ecosystemic interactions. Low-density polymers (i.e., PE, PP) submerge in sedimentary environments due to biofouling, substance adsorption onto surfaces, filling with manufacturing inorganics, association with feces, and adhesion of clay-like particles; fibers and fragments, on the other hand, demonstrate slower velocities, low shear stress and are easily transported at low flow and turbulence parameters as in bedload and sediment traps (Zettler et al., 2013; Corcoran et al., 2015; Zalasiewicz et al., 2015; Frias et al., 2016).

Microplastic-derived debris in the soil ecosystem is divided into three environmental compartments/interfaces: municipal (i.e., wastewater effluent), agricultural (i.e., plastic mulch) and subterranean (i.e., sewage sludge landfill) (Chae and An, 2018). However, there are significant interactions at times between compartments. For example, the sludge of wastewater treatment plants destined for land application (i.e., agricultural areas) contains textile fibers, which in turn act as indicators of sludge in agricultural fields (Habib et al., 1998; Zubris and Richards, 2005; Carr et al., 2016; Dris et al., 2016). As is, sophisticated filtration systems (e.g., continuous backwash, upflow, dual sand microfiltration) in more than 30 New York wastewater treatment plants have been disproven in the removal of microplastics (Discharging Microbeads, 2015). Although microarthropods (i.e., earthworms) and their distribution have been used as bioindicators of plastic contamination in land, further understanding of the 
ecotoxic interaction of microplastics and soil ecosystems requires examination of diverse model species (e.g., invertebrates, insects, plants) (Chae and An, 2018). In the case of fish in aquatic ecosystems, the contamination of the marine environment with foam (i.e., styrene monomer), even without adhered PAHs, has been proven to disrupt the endocrine system and identified as carcinogenic to humans if biomagnified (Carpenter et al.,1972; Pruter, 1987; Lithner et al., 2011). The importance of identifying the biological impacts of microplastics at suborganismal levels (i.e., cellular, molecular) is reflected in policy-making ecological risk assessments, that translate into the establishment of plastic as waste as well as irreversible injury parameters, survival rates and the ecosystem-based adaptation of certain species (Rochman et al., 2016; Nielsen et al., 2020). In this regard, endangerment of biodiversity ( 693 marine species) has been attributed by $92 \%$ of study cases to interactions with meso- and micro-plastics (Gall and Thompson, 2015). Even in 17\% of the cases with indirect interactions, sublethal effects are the consequence of ingestion and entanglement, which further destabilize assemblages as well as trophic interactions (Gall and Thompson, 2015).

\section{Microplastics}

\subsection{Source and production}

As a consequence of human-induced climate change, the melting Arctic Sea ice has been releasing trapped microplastics, that were concentrated in past decades, into the oceans (Obbard et al., 2014). Since 1975, global litter discharged to the oceans (e.g., vessels, military ships) has been estimated at 5.8 million metric tons (Mmt) (NRC, US, 1975). However, consumerism of plastics has exploded commercially since the 1930 with a $620 \%$ increase in global plastic resin production by 2012 . (Hoornweg and Bhada-Tata, 2012; PlasticsEurope, 2013). The origin of these man-made microparticles has not been attributed to current source points, but rather represents a global sink from the past century (Obbard et al., 2014). Furthermore, since the permanent elimination of plastic waste requires an inconvenient use of thermal treatment (i.e., combustion, pyrolysis), the accumulation of plastic debris in freshwater and terrestrial ecosystems has been on the increase (Zubris and Richards, 2005; Rillig, 2012; Wegner et al., 2012; Dris et al., 2016; Reid et al., 2019). In 2015, a global 1950-2015 meta-analysis addressing the end-of-life of primary (i.e., virgin) as well as secondary (i.e., recycled) plastic materials 
(i.e., polymer resins, synthetic fibers, additives) estimated their generation as $8,300 \mathrm{Mmt}$ and the resultant waste as $6,300 \mathrm{Mmt}$, of which $79 \%$ is currently in landfills. This percentage is projected to be $12,000 \mathrm{Mmt}$ by 2050 (Geyer et al., 2017). Moreover, a refined 2010-2016 World Bank global data collection (i.e., 217 countries) estimated the generation of plastic waste for this period as $242 \mathrm{Mmt}$ (Law et al., 2020). According the World Bank data compilation (i.e., 192 coastal countries) for 2010 reported by Jambeck et al. (2015), in order of decreasing plastic waste generation (pwg) and mismanaged waste (mpw), the top five countries include: United States (pwg: $13.77 \mathrm{Mmt}, \mathrm{mpw}$ : $0.27 \mathrm{Mmt}$ ), China (pwg: 11.55 Mmt, mpw: 8.81 Mmt), Brazil (pwg: 4.47 Mmt, mpw: $0.47 \mathrm{Mmt}$ ), Indonesia (pwg: $3.89 \mathrm{Mmt}, \mathrm{mpw}: 3.21$ Mmt), and Turkey (pwg: $2.62 \mathrm{Mmt}$, mpw: $0.48 \mathrm{Mmt}$ ). China is responsible for $28 \%$ of the global production of plastics, and $68 \%$ of global polyester, polyamide, and acrylic fibers (PlasticsEurope, 2016; FiberYear, 2017). In comparison with the US, which is foreseen to increase its mismanaged plastic waste stream $22 \%$ by 2025 , other middle-income countries are expected to double it due to population and economic growth (Hoornweg and Bhada-Tata, 2012). According to Law et al. (2020), the same decreasing order (i.e., pwg, mpw) for 2016 includes the following top five countries: United States (pwg: $42.02 \mathrm{Mmt}$ mpw: $0.68 \mathrm{Mmt}$ ), EU-28 (pwg: 29.89 Mmt, mpw: 0.013 Mmt), India (pwg: $26.32 \mathrm{Mmt}, \mathrm{mpw}$ : $20.79 \mathrm{Mmt}$ ), China (pwg: 21.59 Mmt, mpw: 5.45 Mmt), and Brazil (pwg: 10.67 Mmt, mpw: 2.69 Mmt) (Fig. 1). Nevertheless, independent estimates by Jambeck et al. (2015) and Geyer et al. (2017), indicate the total land-based waste generation from primary plastic (i.e., virgin material) for 2010 amounted to 274.5 Mmt, of which $~ 4.8-12.7 \mathrm{Mmt}$ is mobilized into the ocean as marine plastic debris and eventually fragmented into microplastics. This estimate increased by $5,800 \mathrm{Mmt}$ in 2015 with $12 \%$ made up of polyester, polyamide, and acrylic fibers (Jambeck et al., 2015; Geyer et al., 2017).

A compilation of production statistics from the Global Industry Analysis, together with the American Chemistry Council and other studies, dates back to the 1950 s and accounts for $92 \%$ of all the plastic ever manufactured in the world: nonfiber plastics with additives (i.e., plasticizers, fillers, flame retardants $)(7,300 \mathrm{Mmt} ; \mathrm{PE}=36 \%, \mathrm{PP}=21 \%, \mathrm{PVC}=12 \%, \mathrm{PET}, \mathrm{PU}, \mathrm{PS}=<10 \%)$ and polyester, polyamide and acrylic fibers (1,000 Mmt). $42 \%$ of the nonfibers were destined for packaging, whereas $69 \%$ of the PVC was for the construction sector, which in turn consumes $19 \%$ of the nonfibers group (Mutha et al., 2006; PlasticsEurope, 2006; GIA, 2008; Rajaram, 2009; Geyer et al., 2017). It is important 
to emphasize that the product lifetime distribution of these groups of plastics enters a recycling and reprocessing (i.e., secondary material) phase; however, these hardly displace primary production and end up in the thermal destruction (i.e., incineration) or discarding (i.e., sanitary landfills, dumps, natural environment) phases (Zink and Geyer, 2017). These primary plastics are fragmented into microplastics either by artificial or environmental processes and end up mainly in water. This was confirmed by a global 2007-2013 oceanographic model estimating a total of $\sim 5.25$ trillion buoyant particles, of which microplastics $(<4.75 \mathrm{~mm})$ surpassed expected fragmentation rates, which suggests mechanistic dispersion from the sea surface (Eriksen et al., 2014).

\subsection{Environmentally relevant concentrations}

Efforts have been made using two different computer simulations (i.e., van Sebille, Lebreton) to estimate the abundance of microplastics in different ecosystems. These have predicted that the Mediterranean basin holds the highest floating particle count compared to other basins around the world (Eriksen et al., 2014; van Sebille et al., 2015; Setälä et al., 2016). In furtherance of these models, the work of Güven et al. (2017) found a 58\% occurrence (abundance units: 2.36 particles/specimen) of microplastic litter (i.e., $70 \%$ fibers) in the gastrointestinal tract of 1,337 fish of varied species (i.e., 7 benthopelagic, 5 reef-associated, 12 demersal, 3 pelagic-neritic, 1 pelagic-oceanic) sampled from Turkish territorial waters with concentration values as low and high as $16,339-520,213$ particles $/ \mathrm{km}^{2}$. These values are in agreement with the Maximenko and Lebreton model predictions as well as the 243,853 particles $/ \mathrm{km}^{2}$ measured in 2013. Furthermore, it was revealed that $50 \%$ of these particles are found in water regions that contain $4 \times 10^{5}$ microplastic particles $/ \mathrm{km}^{2}$, whereas $30 \%$ are found in regions with $<10^{6}$ particles $/ \mathrm{km}^{2}$ of particles in all size classes (Lusher et al., 2013; Cózar et al., 2015).

In addition, a recent large field study from East China of over 800 fish collected from Shangai fishery markets, with the Yangtze estuary as their point source, confirmed mesoplastic (i.e. fibers, sheet) and microplastic (i.e. fiber, fragment, pellet) ingestion in 21 sea species and 6 freshwater species. The highest abundance (i.e., items per individual) by water zone category were represented by the following species: Hyporhamphus intermedius ( $3.7 \pm 2.2$ items/individual) and Coilia ectenes ( $4.0 \pm 1.8$ items/individual) for saltwater pelagic fish, Harpodon neherus (3.8 \pm 2.0 items/individual) and Larimitchys 
crocea (4.6 \pm 3.4 items/individual) for saltwater benthopelagic fish, Cyoglossus abreviatus $(6.9 \pm 2.4$ items/individual) and Thamnaconus septrentionalis (7.2 \pm 2.8 items/individual) for saltwater demersal fish, Callionymus planus (4.8 \pm 2.3 items/individual) for saltwater benthic fish, and Pseudorasbora parva (2.5 \pm 1.8 items/individual) and Hypophthalmichthys molitrix (3.8 \pm 2.0 items/individual) for freshwater benthopelagic fish (Jabeen et al., 2017). While saltwater demersal fish were found to have the highest plastic (49.1\% cellophane, 10.6\% PET, $7.9 \%$ polyester) load per individual, this trend differs between water zone categories in other localities such as the North Sea, the Baltic Sea and the English Channel, indicating geographic-specific habitat associations to microplastic classification, distribution (i.e. debris presence in seabed) and ingestion (Lusher et al., 2013; Woodall et al., 2014; Rummel et al., 2016). As an additional parameter, it has been suggested that morphological variations in the gastrointestinal tract of several fishes occur according to their feeding habits. The presence of mesoplastics was abundant in the complex stomach of Pampus cinereus and Psenopsis anomala, whereas narrow stomach-intestine intersections of L. crocea retained more sheets (Khalaf Allah, 2013; Chakrabarti and Ghosh, 2014). A study identified 28 fish species of 14 different families on the Mediterranean coast (environmental concentration: $~ 16,000-520,000$ particles $/ \mathrm{km}^{2}$ ) as polluted with plastic particles in the size range of 0.1$2.5 \mathrm{~mm}$ (i.e., fibers, hard plastic, nylon, rubber, miscellaneous plastic) in their intestines (Güven et al., 2017). Another study in China identified the presence of cellophane-derived fiber microplastics and mesoplastics (5-10 mm size particles) in 27 different species (1-7 items/individual) of combined marine and freshwater fish (Bråte et al., 2016; Jabeen et al., 2017). Many other studies in different fish species have also confirmed the ingestion of non-fiber microplastics, with percentages as high as $35 \%, 68 \%$ and 77\% (Boerger et al., 2010; Davison and Asch, 2011; Lusher et al., 2013; Nadal et al., 2016; Tanaka and Takada, 2016).

In the bivalve population, two commercial shellfish species (i.e., blue mussel, Mytilus edulis; Pacific oyster, Crassostrea gigas) were found to contain a bioconcentration of $\sim 0.47 \pm 0.16$ particles/g of tissue at the time of consumption, which amounts to a human ingestion of 11,000 microplastics particles per year if consumed daily (van Cauwenberghe and Janssen, 2014). China (i.e., Hong Kong, Hainan Island) has been identified internationally as a hotspot for microplastic accumulation due to population density, economic structure and a greater average abundance of particles (i.e., 5,595/m²). Estuarine 
environments, such as that of the Yangtze, are recognized as the primary source of microplastics that effect sea salt manufacturing and have been confirmed in nine commercial bivalve species (i.e., ark clam, Scapharca subcrenata; blood clam, Tegillarca granosa; true mussel, Mytilus galloprovincialis; Yesso, Patinopecten yessoensis; fingerprint oyster, Alectryonella plicatula; Chinese razor clam, Sinonovacula constricta; Manila clam, Ruditapes philippinarum; Asian hard clam, Meretrix Iusoria; iron clam, Cyclina sinensis) (Zhao et al., 2014; Fok and Cheung, 2015; Qiu et al., 2015). Seawater plastic and other anthropogenic contaminants accumulate during saltwater concentration processes, remain after crystallization, and are present in the end-product of commercial salt manufacturering (Serrano et al., 2011). By using micro-Fourier Transform Infrared Spectroscopy (mFTIR), sea salt derived from China's seawater (i.e., table salt, lake salt, rock/well salt) was analyzed and found to be contaminated with an average of $\sim 200$ particles $/ \mathrm{kg}$ of PET- and cellophane-derived microplastic (i.e., fragments, fibers) (Yang et al., 2015). Similarly, commercial table salt in Spain manufactured from the Mediterranean sea contained around $~ 50-280$ particles/kg of PET- and PP-derived microplastics (Iñiguez et al., 2017). Furthermore, several studies have confirmed an average human ingestion of 16,800 plastic particles from water, beer, sea salt and seafood per year in Europe, compared to 110,000 particles/year in China from seafood alone (van Cauwenberghe and Janssen, 2014; Kosuth et al., 2018). These estimates are valuable as they represent human exposure concentrations (i.e., $\sim n g / L$ ) with the capability for biological repercussions (i.e., endocrine-disrupting properties, growth, reproduction, cardiovascular disease) and ecological prevalence even with a $90 \%$ excretion rate as per the Panel on Contaminants in the Food Chain and other studies (Colborn and Thayer, 2000; Lang, 2008; Cedervall et al., 2012; Brander, 2013).

In order to transition from ecosystem-based approaches to ecotoxicological focused studies, a clear identification of microplastic environmental concentrations in surface waters and sediments is necessary. Laboratory data emphasizing the direct physiological effects in organisms at such levels (Franzellitti et al., 2019), and in co-existence with inter-habitat flora or fauna are still in progress, particularly, for later analysis and evaluation of their impact on populations and food webs (Lusher et al., 2017). According to noted Lenz et al. (2015), most microplastic concentrations used in experimental procedures are 2-7 orders-of-magnitude higher compared to those observed in the environment, which is roughly $\sim 1 \mu \mathrm{g} / \mathrm{L}$ according to a comparison of 8 laboratory studies and several field reports. In contrast, a 
meta-analysis by Paul-Pont et al. (2018) based on 27 microplastic measurements (size: 10-1,000 $\mu \mathrm{m}$ ) around the world estimated concentrations at $\sim 518.6 \mu \mathrm{g} / \mathrm{L}$ in surface waters and at $\sim 13.14 \mathrm{mg} / \mathrm{kg}$ in sediments, which is 3 and 4 orders-of-magnitude higher than the one suggested by Lenz et al. (2015). Similarly, Besseling et al. (2014) emphasized that the concentrations used in their experiments are higher than the ones reported in U.S. and Europe freshwater ecosystems (i.e., $0.4-34 \mathrm{ng} / \mathrm{L}$ ) by a factor of $10^{6}$ 108. Thus far, few laboratory studies have established a direct causal relationship between microplastic concentrations of specific ecosystems (i.e., marine waters, freshwater, sediment pore waters) and sublethal effects derived from bioaccumulation in organisms. For example, the impact of 2-6 $\mu \mathrm{m}$ PS microspheres at $23 \mu \mathrm{g} / \mathrm{L}$ on Pacific oysters (C. gigas) fed two different microalgae (i.e., Tisochrysis lutea, Chaetoceros gracilis), on the planktonic crustacean Daphnia magna fed green algae (Scenedesmus obliquus) exposed to $70 \mathrm{~nm}$ PS particles $(0.22-150 \mathrm{mg} / \mathrm{L})$ and co-exposed to algae at different concentrations $(0.88,1.8 \mathrm{mg} / \mathrm{L})$ and fish kairomones, and on the blue mussel ( $M$. edulis) exposed to both $30 \mathrm{~nm}$ (i.e., $100-300 \mathrm{mg} / \mathrm{L}$ ) of PS fed a mixture of microalgae (i.e., T. lutea, Rhodomons marina) and $<25$ $\mu \mathrm{m}$ (i.e. $0.2,20 \mathrm{mg} / \mathrm{L}$ ) of HDPE fed varying concentrations of Pavlova lutheri have been reported (Wegner et al., 2012; Besseling et al., 2014; Sussarellu et al., 2016; Li et al., 2020).

Another study used concentrations of microplastics reported in a four-decade monitoring field study of the NPSG and their correlation with pelagic insect Halobates sericeus sampling, to establish an average $(300 \mathrm{ng} / \mathrm{mL})$ range that allowed the set-up of three experimental groups (i.e. control, virginplastic exposure, marine-plastic exposure) to analyze bioaccumulation from a cocktail of plasticassociated pollutants (i.e. LDPE-derived PAHs, PCBs, PBDEs) at different time frames (i.e. 1-month exposure, 2-month exposure) (Goldstein et al., 2012; Rochman et al., 2013a; 2014). Similarly, Wardrop et al. (2016) co-exposed rainbow fish (Melanotaenia fluviatilis) to personal care product-derived microbeads at a concentration of $1 \mathrm{mg} / \mathrm{L}$ and PBDEs at a concentration of $200 \mathrm{ng} / \mathrm{g}$, which are levels of plastic micropollutants reported from the open ocean and urban beaches (Ogata et al., 2009; Hirai et al., 2011). Furthermore, the work of Ribeiro et al. (2017) not only utalized reported environmental concentrations for laboratory experiments that exposed clams (Scrobicularia plana) to $1 \mathrm{mg} / \mathrm{L}(20 \mu \mathrm{m}$ ) of PS microplastics, but also made a comparison of varied concentrations (e.g., M. edulis: $0.51 \mu \mathrm{g} / \mathrm{L}$ ) and abundances (e.g., M. edulis: 50 particles/mL, $10 \mu \mathrm{m}$; Mytilus trossulus: 1,000 particles $/ \mathrm{mL}, 10 \mu \mathrm{m}$; Crassostrea virginica: 
1,000 particles/mL, $10 \mu \mathrm{m}$; C. gigas: 118 particles $/ \mathrm{mL}, 6 \mu \mathrm{m}$ ) with different particle sizes across sediments and water bodies (Liebezeit and Dubaish, 2012; Song et al., 2014). As it is clear from these studies, consensus on a one-size-fits-all environmentally relevant concentration and co-exposure to interhabitat organisms is still lacking.

\subsection{Biological impact and human health dimension}

The distribution of PS microspheres (micro-PS) and microfibers results in biological and physiological repercussions for marine biota, especially for filter-feeder organisms (e.g., Eastern oyster, C. virginica; Pacific oyster, C. gigas) that hold ecological value in coastal environments, as has been exhibited in laboratory settings, wild populations, and farmed animals (von Moos et al., 2012; Cole et al., 2013; Mathalon and Hill, 2014; Sussarellu et al., 2016; Gaspar et al., 2018; Murphy, 2018). The ubiquitous nature of synthetic polymers (i.e., micro-PS) contributes to the biomagnification of different sizes (e.g., 2-6 $\mu \mathrm{m}$ ) of microplastic particulates in both the Pacific and the Atlantic ocean (Sussarellu et

al., 2016). The Eastern oyster (also called American oyster, Atlantic oyster, or Virginia oyster; C. virginica) is considered an ecosystem engineer that assists with the restoration of reefs by controlling subpopulations of algae as well as the process of nutrient filtration, de-nitrification, and carbon sequestration (Browne et al., 2013; Hernández et al., 2018). In a controlled study, pacific oysters exposed to micro-PS for two months exhibited $38 \%$ and $23 \%$ reductions in oocyte production and sperm velocity, respectively (Sussarellu et al., 2016). In two different studies, microplastics in the gastrointestinal tracts of crabs and mussels were observed to translocate to other tissues and fish fed microplastic particles translocated the particles to their liver tissues (Browne et al., 2008; Watts et al., 2014; Avio et al., 2015; Watts et al., 2015). Another dimension of exposure to PE, PP and PS microplastics is their recently discovered capacity for microbial colonization (e.g., Vibrio parahaemolyticus), and thus may act as pathogenic vectors that can disperse pathogens to higher trophic levels and eventually to humans (Zettler et al., 2013; McCormick et al., 2014; Kirstein et al., 2016). In this regard, the presence of microplastic bioaccumulation in fish, shellfish, and mollusks around the globe (i.e., Asia, Europe, North America, South America) pose a threat to human health due to over $125 \times 10^{6}$ tons of combined capture and 
aquaculture seafood consumption (Rochman et al., 2015; Baechler et al., 2020; Mai et al., 2020) (Fig. 1, Table 2, Supplementary Table 1).

As a secondary trophic transfer source, microplastic-derived nanoplastics $(<100 \mathrm{~nm}$ size particles) might also pose a threat to human beings as they inflict biological stress through leaching additives, monomers (i.e., PDBEs, PCBs) and sorbed environmental contaminants (i.e., persistent organic pollutants -POPs) (Teuten et al., 2009; Hirai et al., 2011; Mizukawa et al., 2013; Chua et al., 2014; Rochman, et al., 2015; Revel et al., 2018). This has also been confirmed without regard to trophic transfer sources, as these microparticles undergo progressive chemical breakage down to nanoscale fragments, present different biological interactions according to their morphologies (i.e., cone, stick, needle-like shape, amorphous, irregular), and possess different crystalline states that affect degradation behavior (i.e., permeability, hydration, swelling) (Cole et al., 2011; Lambert et al., 2014). Concerns have been heightened as to the oral ingestion of nanoplastic particles, derived from microplastic particles ingested by fish destined for human consumption, as these have been detected in human stool samples and proven to be absorbed through epithelia and systemically biodistributed to organs (Bouwmeester et al., 2015; Phillips and Bonner, 2015; Peters et al., 2017; Santana et al., 2017; Wright and Kelley, 2017; Liebmann et al., 2018; Su et al., 2019). Laboratory and field studies have detected both the bioaccumulation and transfer of PBDE plastics in tissues of aquatic (i.e., teleost fish) as well as terrestrial (i.e., lugworms, oceanic sea birds) organisms as per the identification of artificial and natural prey items (Siddiqi et al., 2003; Browne et al., 2013; Rochman et al., 2013; Tanaka et al., 2013). Lower trophic level prey bioaccumulate microplastic debris and indirectly disrupt higher trophic level organisms via blockage of the alimentary canal or directly by biomagnifying particles that reach humans at the end of the food chain (Murray and Cowie, 2011; Cole et al., 2013; Farrell and Nelson, 2013; Rochman et al., 2017).

Bioavailability and biotransformation capacity of microplastics in the presence of PAHs was reported in fish juveniles (e.g., common goby, Pomatoschitus microps) exposed simultaneously to PE microspheres and pyrene, which impaired the aerobic pathway of energy production (Oliveira et al., 2013). Similarly, the Mediterranean mussel (M. galloprovincialis) was shown to transfer pyrenecontaminated PE and PS microparticles via the digestive gland and develop cellular alterations (i.e., neurotoxicity, antioxidant system, peroxisomal proliferation, lysosomal compartment), and the cladoceran 
D. magna (a small planktonic crustacean) was immobilized due to the physical damage caused by exposure to phenanthrene-contaminated nanoparticles as opposed to compound-free (Avio et al., 2015). However, shellfish and mollusks represent a higher risk of microplastic and nanoplastic ingestion for humans as these have a larger retention capacity in their gastrointestinal tracts (van Cauwenberghe et al., 2015; Güven et al., 2017; Revel et al., 2018; Lehner et al., 2019). Interestingly, a study estimated that a minimum of 39,000 particles were consumed annually per person in the US through food intake alone, and 78,000 through tap water intake (Cox et al., 2019). The penetration of nanoplastic particles across the striatum corneum in the human skin has a minimum limit of $100 \mathrm{~nm}$, however, nanoparticles have been found in skin biopsies (Sykes et al., 2014). Furthermore, additives in nanoplastics other than the aforementioned (i.e., surfactants, lubricants, fragrances, pigments, biocides) also have the potential to induce toxicity mostly via dermal exposure (Andrady and Neal, 2009; Lambert et al., 2014; Revel et al., 2018). At low environmentally relevant concentrations, PVC (i.e., vinyl chloride monomer: 0.025-3.22 ppm), styrene leachates, phthalates and BPA (i.e., 0.3-5 ng/mL) have been linked to cancer, neurological effects and endocrine disruption in humans, as per the Agency for Toxic Substances and Disease Registry and other studies (Awara et al., 1998; Hugo et al., 2008).

At subcellular levels, on the other hand, the Caco-2 cell line has been successful for in vivo and in vitro studies that elucidate the mechanisms of micro- and nano-plastic internalization (i.e., transcytosis) via the intestinal barrier and their final destination in lysosomes, as well as the physico-chemical properties that affect uptake and biopersistence (Kulkarni and Feng, 2013; Walczak et al., 2015; Reinholz et al., 2018). A mouse in vivo model fed with fluorescent PS microparticles for 28 days demonstrated kinetic-dependent and size-dependent accumulation in several organs (i.e., liver, gut, kidney) (Deng et al., 2017). In mussels, on the other hand, $10 \mu \mathrm{m}$ PS spheres were detected in the circulatory system whereas $5 \mu \mathrm{m}$ spheres were found in zebrafish (Danio rerio) liver (Lu et al., 2016). Furthermore, microplastics have been found in the milk and cerebrospinal fluid of lactating women (Wright and Kelley, 2017).

In furtherance of the toxic effects of polymers in humans, significant investigations have demonstrated the biological effects of these at the molecular level (e.g., cytotoxicity, oxidative stress, immune response, genotoxicity) (Rubio et al., 2020). As is, both 0.1 and $5 \mu \mathrm{m}$ PS particles were able to 
disrupt the mitochondrial membrane potential of Caco-2 cell line, and $1 \mu \mathrm{m}$ fluorescent PS spheres reduced THP-1 monocyte-like cell viability at concentrations above $50 \mu \mathrm{m} / \mathrm{mL}$ (Stock et al., 2019; Wu et al., 2019). BeWo b30 placental trophoblast cells (i.e., human placental-derived choriocarcinoma cell line) altered both their metabolic and mitochondrial activities when exposed to $50 \mathrm{~nm}$-sized (concentration: 5 $\mu \mathrm{g} / \mathrm{mL}$ ) and $0.5 \mu \mathrm{m}$-sized (concentration: $0.01-10 \mu \mathrm{g} / \mathrm{mL}$ ) COOH-modified PS particles, respectively (Hesler et al., 2019). BeWo b30 cells were cultured in endothelial cell growth medium and cell viability assessed using MTS assay, and both metabolic activity (i.e., [ 120\%] nano-PS) and mitochondrial activity (i.e., [ 160\%] micro-PS) were significantly increased $(p \leq .05)$ (Hesler et al., 2019). Similar results were observed in BEAS-2B human lung epithelial cells exposed to $60 \mathrm{~nm}$ PS spheres (10 $\mathrm{gg} / \mathrm{mL})$, as the endoplasmic reticulum underwent autophagic degradation (Lim et al., 2019). Additionally, the NIH 3T3 cell line showed high cellular toxicity after exposure to amino-modified PS nanoparticles with positive charge (Liu et al., 2011).

Regarding oxidative stress, dermal fibroblasts and murine macrophages demonstrated a $30 \%$ elevation of reactive oxygen species (ROS) when exposed to $20 \mu \mathrm{m}$ PE microparticles at a limiting threshold of $1,000 \mu \mathrm{g} / \mathrm{mL}$ (Hwang et al., 2019). The monogonont rotifer Brachionus koreanus developed size-dependent toxicity when exposed to $10 \mu \mathrm{g} / \mathrm{mL}$ of $0.05-\mu \mathrm{m}$ PS microbeads, compared to 0.5 - and 6$\mu \mathrm{m}$ sizes (Jeong et al., 2016). Increased antioxidant enzyme activities (i.e., GHS, SOD, GR, GPx, GST), ROS levels and phosphorylated mitogen-activated protein kinases (MAPKs) (i.e., p-ERK, p-JNK, p-p38) led to reductions in growth rate (i.e., $\sim 63 \%$ ), fecundity (i.e., 18\%), lifespan (i.e., 22\%) and a longer reproduction time (i.e., control: 25.41 h, 0.05- $\mu \mathrm{m}$ : 27.03 h) (Jeong et al., 2016). Similarly, the marine copepod Paracyclopina nana exhibited a significant increase in intracellular ROS level when exposed to $0.05-\mu \mathrm{m}$ microbeads at varying concentrations $(0.1-20 \mu \mathrm{g} / \mathrm{mL})$, which positively correlated with increased p-ERK and p38 with Nrf2 phosphorylation (Jeong et al., 2017). An in vitro study found that in antiinflammatory macrophages, the expression of scavenger receptors CD163 and CD200R was impaired upon exposure to PS nanoparticles (Fuchs et al., 2016). Exposure of human THP-1 macrophages to positively charged PS nanoparticles (i.e., $50 \mathrm{~nm}$ ) significantly induced DNA damage and impaired repair machinery (Paget et al., 2015). Moreover, genotoxicity studies found that three different cell lines (i.e., Hs27, HeLa, NIH 3T3) were susceptible when exposed to varying concentrations of both positively (i.e., 
amino-modified) and negatively (i.e., carboxylated -NH2ePS) charged PS nanoparticles, as fragmented micronuclei increased according to chromosome breakage assay, G0/G1 phase was extended, and cyclin D and E levels were reduced (Liu et al., 2011; Poma et al., 2019).

Taken together, the biological impact of micro- and nano-plastics on the human health spectrum is reflected in these research works. However, studies regarding gut mucosa are still lacking and are imperative to a wide range of health conditions (e.g., microbial infection, irritable bowel syndrome, inflammatory bowel disease, celiac disease, metabolic syndrome, non-alcoholic fatty liver disease, diabetes, septic shock, etc.) (Groschwitz and Hogan, 2009; Sánchez de Medina et al., 2014). In juvenile Chinese mitten crab (Eriocheir sinensis), immune enzyme activity and intestinal microflora was identified after exposure to 0.04 - and $40 \mathrm{mg} / \mathrm{L}$ of $5 \mu \mathrm{m}$ PS microspheres for 21 days (Liu et al., 2019). Exposure significantly decreased the content of immune-related factors (i.e., haemocyanin, alkaline phosphatase, phenoloxidase, lysozyme, acid phosphatase) in haemolymph and the hepatopancreas, increased the expression of caspase and myeloid differentiation factor gene (i.e., MyD88) in haemocytes, and the relative abundance of Firmicutes and Bacteroidetes was increased at $40 \mathrm{mg} / \mathrm{L}$ whereas that of Fusobacteria and Proteobacteria decreased (Liu et al., 2019). In zebrafish (D. rerio), $20 \mathrm{mg} / \mathrm{L}$ concentrations of $15 \mu \mathrm{m}$ PS microbeads and fragments, and PP microfibers (i.e., length: $25-\mu \mathrm{m}$ ) caused oxidative stress (i.e., 70 to $130 \mathrm{U} / \mathrm{mg}$ SOD protein), intestinal permeability (i.e., 6 to $2 \mu \mathrm{mol} / \mathrm{mg} \mathrm{D}$-Lac protein), intestinal inflammation (i.e., 6 to $10 \mathrm{ng} / \mathrm{g} \mathrm{IL}-1 \alpha$ protein), and severe intestinal toxicity by inducing gut microbiota dysbiosis with changes in gut microbiota relative abundance (i.e., $\sim 30-40 \%$ Proteobacteria; 11-3\% Actinobacteria; 10-5\% Aeromonas; 2-1\% Pseudomonas; 3-13\% Gordonia) (Qiao et al., 2019). While in the common soil collembolan Folsomia candida, exposure to $80-250 \mu \mathrm{m}$ PVC particles (i.e., $1 \mathrm{~g} / \mathrm{kg}$ per dry soil sediment) significantly decreased the abundance of Bacteroidetes (i.e., 29.7 to $2 \%$ ) and increased Firmicutes (i.e., 11.2 to $43 \%$ ) in gut microbiota, a decline in growth (16.8\%) and reproduction (28.8\%) was observed along with an increase of $\delta^{15} \mathrm{~N}$ and $\delta^{13} \mathrm{C}$ isotopic incorporation in tissues (Zhu et al., 2018).

In humans, poor nutritional habits of developed societies promote inflammatory bowel disease (IBS), and studies on patients with IBS indicate they have an enhanced uptake of microparticles as opposed to healthy people (M'Koma, 2013; Schmidt et al., 2013). This evidence resembles two mouse 
model laboratory experiments. Mice fed for 5 weeks with PS microparticles $(1,000 \mu \mathrm{g} / \mathrm{L})$ resulted in decreased gut mucus secretion and microbiota (i.e., Firmicutes, $\alpha$-Proteobacteria filum), and those fed for 6 weeks with pristine and fluorescent microparticles resulted in reduced intestinal mucus secretion, damaged intestinal barrier, and altered microbiota (i.e., Actinobacteria) (Lu et al., 2018; Jin et al., 2019). The work of Garnett et al. (2012) has also indicated that polymer nanoparticles (i.e., ammonium palmitoyl glycol chitosan), which are nanoplastic particles that are preliminary models for used in drug delivery, recirculate into the bloodstream once they interact with $\mathrm{M}$ cells in the gut and bio-distribute to the lymphatic system, liver and gall bladder before excretion. Therefore, further studies can elucidate the release of biocides and the potential interaction of plasticizers and additives with steroid receptors and signal transduction pathways using this model as these outcomes may pose a novel risk to gut flora (EFSA, 2011; Galloway et al., 2017). Cancer research studies can analyze the effects of micro- and nano-plastic particle translocation in mucosal cells, with the addition of parameters such as sorption of luminal molecules onto their surfaces (Powell et al., 2010).

\subsection{Animal ingestion and entanglement}

The ingestion of plastic debris has been reported in terrestrial and marine organisms (e.g., seabirds, turtles, whales, seals, etc.), and since the 1960s, it has increased proportionally to the production of new plastics (Pettit et al., 2011; Kühn et al., 2015). The first seabird species, Leach's storm petrel (Oceanodroma leucorhoa), that was reported to have ingested plastic debris dates back to 1962 (Rothstein, 1973). In a controlled study, a comparison between sea turtles that had died of plastic ingestion (i.e., gut impaction, perforation) and unrelated causes demonstrated that $\sim 50 \%$ mortality was achieved per every $\sim 14$ pieces of plastic found in their gut (Wilcox et al., 2018). In 1972, a study demonstrated that 8 out of 14 species of larval fishes sampled had ingested plastic debris as per their gut contents (Carpenter et al., 1972). According to a survey study, the probability that sea turtles ingest plastic debris is $\sim 100 \%$ compared to whales ( $59 \%)$, seals ( 36\%) and seabirds $(40 \%)$, due to their ingestion of plastics at all the stages of their life cycle (Kühn et al., 2015). For the leatherback turtle, Dermochelys coriacea, the first ingestion of plastic debris was reported in 1968 (Mrosovsky et al., 2009). 
The sperm whale, Physeter macrocephalus, was first reported to have ingested plastic debris in 1979 (de Stephanis et al., 2013).

After the first cases of marine biota contaminated with plastic in their gut began to be documented after the overproduction of plastic by the manufacturing industry in the $1950 \mathrm{~s}$, the reporting of samples with plastic ingestion were more common during the 1970s. However, plastic products became more emergent during the 2000s, a negative correlation was found in the number of plastic ingestion cases which reached a plateau similar to that of the 1980s (Kühn et al., 2015). Throughout the past seven decades, a variety of studies that have monitored the ingestion of plastic particles in terrestrial and aquatic organisms have claimed the reappearance of certain trends. Furthermore, global distribution models can estimate the co-occurrence and encounter rates of both plastic pollution and organisms spatio-temporally, with potential indications of ecological risk (Eriksen et al., 2014; Schuyler et al., 2015). Nevertheless, it is certain that these particles exist today in major terrestrial, freshwater, and marine food webs, and that they possibly serve as driving factors in the flux of energy between individuals, in population changes between ecosystems and/or ecological networks, and ultimately effect human health through trophic transfer (Carbery et al., 2018; de Souza Machado et al., 2018; Windsor et al., 2019). As of 2020, with the increasing meso- and micro-plastic pollution hotspots (i.e., biodegradation, odorant release, infochemicals) in different ocean gyres around the world, it is estimated that plastic ingestion has been reported in over 50 freshwater and 690 marine species (Rochman et al., 2013b; Gall and Thompson, 2015; Savoca et al., 2016; Galloway et al., 2017; Jâms et al., 2020).

\subsubsection{Foraging strategy}

According to many studies since the 1980 s, seabird species that consistently forage on bins and landfills near marine habitats seem to be the most statistically affected by the ingestion of plastic debris (Day et al., 1985). The two main reasons that establish the relationship between foraging strategy and plastic ingestion-induced mortality in seabirds is the confusion of prey with plastic, and through trophic transfer from species fed on (i.e., crustaceans, cephalopods) (Kühn et al., 2015). A study confirmed that $80 \%$ of the PS foam debris off the Dutch coast had peckmarks from seabirds performing foraging strategy (Cadée, 2002). Being a key trophic link among primary producers and top consumers in the marine food 
chain, a study on the pelagic copepod, Calanus helgolandicus, showed that exposure to $20 \mu \mathrm{m}$ PS beads significantly decreased reproductive output due to energetic depletion (Cole et al., 2015b). Furthermore, a laboratory study on feeding rates, with the implementation of fluorescent-coherent anti-Stokes Raman scattering (fCARS) across 13 zooplankton taxa (e.g., Centropages typicus) from the northeast Atlantic, revealed an average ingestion capacity of 1.7-30.6 $\mu \mathrm{m}$ PS beads as well as significantly reduced algal feeding (Cole et al., 2013). Another study on the ingestion of plastic microfibers by the Norway lobster, Nephrops norvegicus, from multiple areas (i.e., Clyde Sea, North Minch, North Sea) indicated retention despite excretion through ecdysis, due to their complex gut structure (Welden and Cowie, 2016). In a 4week chronic exposure experiment examining the fate and biotransformation of ingested PP rope microfibers in the common littoral crab, Carcinus maenas, exposure was found to significantly reduce food consumption as well as energy budgets available for growth (Watts et al., 2014). In addition, a multiphoton imaging study that exposed $C$. maenas to fluorescently labeled 8-10 $\mu \mathrm{m}$ PS microspheres, found that the ingested particles were retained up to 21 days when inspired through the gills (Watts et al., 2014). As tubenose seabird species have the capacity to digest food in two stomachs, they are more prone to retain ingested plastic debris in their gut compared to other species that have the habit of regurgitation (Kühn et al., 2015). Foraging strategy also plays a role in the mortality of sea turtles as they confuse plastic bags for their primary prey which is jellyfish (Kühn et al., 2015). Marine filter-feeders such as the goose barnacle (Leps spp.), mussels ( $M$. edulis), and the minke whale (Balaenoptera acutorostrata), also ingest plastic debris despite their capacity to eject non-food items before entering the digestive system (de Pierrepont et al., 2005; Goldstein and Goodwin, 2013; van Cauwenberghe and Janssen, 2014). As opposed to most teleost fishes, filter-feeding fish such as the herring, Clupea harengus, in the North Sea and the horse mackerel, Trachurus trachurus, in the English Channel have been reported with plastic ingestion (Foekema et al., 2013; Lusher et al., 2013).

A report on lugworms, A. marina, exposed to sediments with 5\% PVC microplastic in composition indicated that passive ingestion presorbs the pollutants as well as chemical additives (i.e., nonylphenol, phenanthrene, Triclosan, PBDE-47) of the particles (Browne et al., 2013). Furthermore, these compounds produced biological effects at the cellular level which impaired coelomocyte bacterial removal up to $60 \%$, increased mortality rate by $55 \%$, and increased the susceptibility to oxidative stress by $30 \%$ (Browne et 
al., 2013). Similarly, lungworms exposed to an environmentally relevant concentration (global $3 \%$ by weight) of unplasticised PVC showed a 50\% energy depletion due to reduced feeding activity, extended gut resistance and inflammation (Wright et al., 2013). A. marina exposed to natively contaminated sediment with $7.4 \%$ PS displayed reduced feeding activity and a significant bioaccumulation that was exacerbated by the adhesion of 19 types of PCBs onto the microparticles 1.1-3.6-fold (Besseling et al., 2013). Blue mussels exposed for $96-\mathrm{h}$ to additive-free HDPE particles $(0-80 \mu \mathrm{m})$ displayed progressive lysosomal accumulation and destabilization, as well as an inflammatory response triggered by the formation of granulocytomas (von Moos et al., 2012).

\subsubsection{Passive ingestion}

As a subcategory of plastic ingestion incidents, entanglement is a contrasting phenomenon compared to the foraging strategy, since curiosity-driven animals willfully examine plastic items and either ingurgitate or trap themselves in them (Kühn et al., 2015). The main reason that animals have an appeal to certain colors of plastic debris is that they resemble the color of their usual preys, such as the seabirds greater shearwater (Puffinus gravis), red phalarope (Phalaropus fulicarius), and parakeet auklet (Aethia psittacula) (Day et al., 1985; Moser and Lee, 1992). Additionally, most species in marine and coastal habitats are exposed especially to light-colored plastic particles given that these were reported as abundant in the Sargasso Sea, South Atlantic, and North Pacific (Carpenter and Smith, 1972; Day et al., 1985; Ryan, 1987). For sea turtles, light-colored translucent plastics that are shaped like jellyfish while in water are often ingested (Tourinho et al., 2010). In the North Pacific central gyre, mesopelagic fish (e.g., Alepisaurus ferox) seemed to prefer white, blue, and other light-colored plastics as these were found in their gut contents (Boerger et al., 2010). On the contrary, dark-colored plastics were preferred by both pelagic and demersal fish in the English Channel (Lusher et al., 2013). The Norway lobster, $N$. norvegicus, commonly ingests translucent plastics as reported by Murray and Cowie (2011). Interestingly, large sized planktivorous fish inhabiting the North Pacific gyre were more abundant in plastic gut contents compared to smaller and younger individuals (Boerger et al., 2010). The population of organisms, known as the rafting assemblage (e.g., gooseneck barnacle, Lepas spp.), was investigated in the NPSG and 
33.5\% were found to contain 1-30 particles of microplastic debris (i.e., PEs, PPs, PS particles) retained in their gastrointestinal tract (Goldstein et al., 2013).

The correlation between water motion and the ageing of the species is negative for sea turtles as juveniles swim along plastic-residing drift-lines in comparison to adults (Plotkin and Amos, 1990). In several seabird species such as the northern fulmars (Fulmarus glacialis), flesh-footed shearwater (Puffinus carneipes), short-tailed shearwater (Puffinus tenuirostris), and Laysan albatrosses (Phoebastria immutabilis), younger birds have been found to contain more abundant microplastic contents than adults (Auman et al., 1997; Hutton et al., 2008; van Franeker et al., 2011). The same trend was found in samples of the franciscana dolphin, Plontoporia blainvillei, harbor seal, Phoca vitulina, and the Norway lobster that feeds on infaunal polychaetes during their younger years (Denuncio et al., 2011; Bravo Rebolledo et al., 2013; Kühn et al., 2015).

Although mortality in several species (e.g., penguins, seabirds, marine turtles, sperm whale) is induced directly by plastic ingestion, the sublethal effects have been acknowledged as more significant and in need of further study across taxa (Colabuono et al., 2009; Tourinho et al., 2010; Brandão et al., 2011; de Stephanis et al., 2013). Plastic ingestion has been acknowledged as an exacerbating factor in the survival of species like the Laysan albatross in which it worsens nutrition and dehydration, tube-nosed seabirds in which debris limits the food capacity of the stomach, fish where it partially blocks the digestive tract, and in general as it triggers receptors in the brain into satation (Auman, Ludwig et al., 1997; Kühn et al., 2015). A variety of 1-10 mm synthetic polymer particles (i.e., PE, PP, PVC, PET, nylon) in different shapes (i.e., sheets, fragments threads) have been identified in the gastrointestinal tract contents of the baleen whale, Megaptera novaeangliae, however, studies are still needed for the fate and sublethal effects of these (Besseling et al., 2015). A comparative study of different fishes (e.g., herring, whiting, horse mackerel, haddock, Atlantic mackerel, cod, etc.) exposed to plastic microfibers at different locations (i.e., North Sea, English Channel) revealed that air-borne contamination in the environment is a determinant factor in teleost species with the highest frequency of ingestion (Foekema et al., 2013).

\subsubsection{Vertical export and nanoplastic distribution models}


The process that catalyzes the distribution of ingested plastics through marine and terrestrial biota is known as bio-transportation, and it can be further categorized into trophic transfer (e.g., secondary ingestion), excretion (e.g., zooplankton feces), fouling processes (e.g., marine snow bacteria) or vertical export (e.g., migratory behavior of fish) (Choy and Drazen, 2013; Cole et al., 2013; van Cauwenberghe et al., 2013). In addition, microplastic monitoring datasets still face major challenges to this day, such as temporal trends that largely modify spatial distributions, the adherence of contaminants in large plastics that contribute to negative buoyancy over different timescales, and the subsequent sinking of fragmented particles (i.e., nanoplastics) to the deep sea (Lobelle and Cunliffe, 2011; van Cauwenberghe et al., 2013; Cozar et al., 2014, 2015; Law, 2017). The analysis of water columns throughout sublittoral and beach sediments around the world has demonstrated that the accumulation of microplastics is primarily localized to the continental shelf, however, deep-sea sediments (i.e., 1,1005,000 m depth) have counter-balanced this assumption (van Cauwenberghe et al., 2013). It is important to mention that current global models based on computer simulations only account for plastic pollution at the ocean surface mixing zone, which neglects the amount of plastic that is ingested and where trophic transfer occurs by marine species at depths greater than 4,000 m. For example, a study at Monterey Bay, USA, which accounted for the vertical distribution and biological transport of microplastics, found most microplastics were confined to the epipelagic and mesopelagic marine zones (i.e., 200-1,000 m depth) (Eriksen et al., 2014; van Sebille et al., 2015; Koelmans et al., 2017; Choy et al., 2019). Studies addressing the deep-sea (i.e., Atlantic ocean, Mediterranean sea, Indian ocean) as a potential sink for microplastics have demonstrated that microfibers (i.e., rayon, polyester, polyamides, acetate, acrylic) are 4-fold more abundant in sediment samples ( 13.4 \pm 3.5 particles $/ 50 \mathrm{~mL})$ than at the surface (Woodall et al., 2014). Polyester along with PP and PE remain the most detected microfiber polymers according to several studies at different estuarine shorelines across the globe (Rios et al., 2007; Browne et al., 2010; Browne et al., 2011; Lusher et al., 2013; Obbard et al., 2014). Wind patterns and depositional regimes affect the spatial distribution of both meso- and micro-plastics, and dictate where materials of different density (i.e., PVC, polyester, polyamide) accumulate in the water column (Browne et al., 2010).

A joint behavioral and in vitro study on the algae-to-zooplankton trophic transfer of PS nanoparticles demonstrated direct biological effects in lipid metabolism (i.e., cholesterol ratio and 
distribution) at the cellular level (i.e., binding to apolipoprotein A-I) when ingested by fish (Cedervall et al., 2012). Similarly, an uptake of nano-PS beads ( 30 nm) at increasing algae (i.e., Plavovla lutheri) concentrations was found to alter the behavior of the blue mussel, reflected by the production of pseudofaeces and reduced filtering activity (Wegner et al., 2012). Nematodes (Caenorhabditis elegans) exposed to a nano-PS particle concentration of $1 \mu \mathrm{g} / \mathrm{L}$, for the larvae-to-adult stage (i.e., day 1 ) period, enhanced the toxic effects of a post-exposure concentration (i.e., $1 \mu \mathrm{g} / \mathrm{L}$ ) of titanium dioxide nanoparticles ( $\mathrm{TiO}_{2}-\mathrm{NPS}$ ), showed decreased locomotion behavior, and the induction of ROS in the intestines (Dong et al., 2018). Additionally, co-exposure at the same concentrations caused oxidative stress, reflected in the increased expression of sod-2 and sod-3 genes and the nuclear translocation of GFP-tagged skn-1, a Nrf protein-encoding gene involved in antioxidant regulation (Dong et al., 2018). The same nematode species was co-exposed to environmentally relevant concentrations of nano-PS (i.e., $1 \mu \mathrm{g} / \mathrm{L}$ ) and microcystin-LR (MC-LR, a cyanobacterial toxin) (i.e., $0.1 \mu \mathrm{g} / \mathrm{L}$ ), in which exposure to a solid phase and resuspension of nano-PS/MC-LR mixture significantly reduced brood size, locomotion behavior, increased intestinal permeability (a cellular toxicity contributor), severely increased intestinal ROS production, significantly decreased the expression of intestinal barrier genes (i.e., acs-22, pkc-3, hmp-2), and significantly increased the expression of mitochondrial respiratory chain (i.e., isp-1, clk-1) and antioxidant defense system (i.e., sod-2, sod-3, sod-4, ctl-1, ctl-3) genes, compared to a more moderate toxicity in the liquid phase mixture (Qu et al., 2019).

In the freshwater flea, Daphnia pulex, the median lethal concentration of $75-\mathrm{nm}$ monodisperse PS microspheres after 48-h (i.e., $\mathrm{LC}_{50}: 76.69 \mathrm{mg} / \mathrm{L}$ ) was identified as per acute toxicity analysis on neonates (i.e., concentration: 10-400 mg/L; mortality: 4\% and 100\%) (Liu et al., 2019). Chronic toxicity (i.e., $21 \mathrm{~d}$ ) at varying concentrations (i.e., $0.1-2 \mathrm{mg} / \mathrm{L}$ ) revealed reduced body length, growth rate, and relative gene expression of antioxidants (i.e., SOD, GST, GPX, CAT) and heat shock proteins (i.e., HSP70, HSP90) (Liu et al., 2019). Similarly, using RNA-Seq, 208 differentially expressed genes were detected in D. pulex exposed for $96-\mathrm{h}$ to $71-\mathrm{nm}$ nano-PS particles, with significant changes in pathways related to biological processes (i.e., paranodal junction assembly, myelination, neuron projection morphogenesis), cellular components (i.e., voltage-gated potassium channel complex, organelle membrane, endoplasmic reticulum membrane), and molecular functions (i.e., iron ion binding, heme binding, ATP binding) (Liu et 
al., 2021). Zebrafish has been an excellent model for nanoplastic bioaccumulation and neurotoxicity (Zhang et al., 2020). Recently, Chen et al. (2017) demonstrated that a 3-day co-exposure of $D$. rerio to BPA (i.e., 3, 20, 43, and $85 \mu \mathrm{m}$ ) and 50-nm PS particles (i.e., $1 \mathrm{mg} / \mathrm{L}$ ) enhanced bioaccumulation in viscera and head ( 2.2-2.6-fold), and also led to up-regulation of myelin basic protein in central nervous system (CNS) and acetylcholinesterase inhibition.

\section{Methods for microplastic monitoring and impact assessment}

\subsection{Sampling design}

Proposed satellite tracking models (2015-2025) of sea surface microplastics have been resourceful for the determination of potential removal locations in the marine environment (Sherman and Sebille, 2016). Together with ecosystemic approach (i.e., phytoplankton growth) models, the China coast and the Indonesian Archipielago have been depicted as primary microplastic removal locations (Sherman and Sebille, 2016). Estimations indicate that $\sim 30$ plastic collectors (capture efficiency $=45 \%$ ) can remove $31 \%$ of the microplastic mass in these locations and increase phytoplankton growth by $46 \%$ (Sherman and Sebille, 2016). These tracking and sampling methods for microplastics depend on temporal variations (i.e., tidal conditions, short-term wind and rain events, monsoons, wind-induced downward mixing) as well as medium-to-small scale spatial variations, which require sampling replicates such as can be completed with three 15-min trawling events using a neuston net (GESAMP, 2019).

As such, the five sampling methods for the collection of particles at the water surface level include: (1) net tows (i.e., manta trawl, neuston net) with a typical rectangular shape of 0.5-1.0 m width and 0.4 height, length of 1-8 m, and a mesh size of 200-333 $\mu \mathrm{m}$; (2) mega nets (i.e. $4 \mathrm{~m}$ wide); (3) bulk water sample, from a vessel with a known volume; (4) visual observation from a ship (i.e., SLR camera) with the implementation of fixed width transects; and (5) photographic and aerial surveys (i.e., airplane, drone) for mega-litter hotspots that cover a large area (Ryan, 2013; Song et al., 2014; Virsek et al., 2016; Lebreton et al., 2018). On the other hand, water column sampling includes six typical methods: (1) bongo/horizontally hauled plankton nets (i.e., cylindrical-conical shaped) used for mid-water sampling; (2) underway pumps (i.e., vessel seawater intake), which allow for contamination control; (3) submersible pumps (i.e., deck pump) in a stationary stance; (4) bulk sample (i.e. large volumes) with the risk of 
contamination; (5) CPR (i.e., continuous plankton recorder) used at $10 \mathrm{~m}$ depths and for long distances; and (6) fisheries observer (i.e., towed pelagic fishing gear) which is opportunistic as opposed to systematic (Thompson et al., 2004; Doyle et al., 2011; Desforges et al., 2014; Lusher et al., 2014; Song et al 2014; Setälä et al., 2016; Uhrin et al., 2020).

For surface macroplastic litter monitoring, in addition to sophisticated technology (i.e., ocean thermal energy, acoustic monitoring, satellites), simple recommendations compatible with the UN Environment Programme have been implemented according to seafloor depth: for less than $30 \mathrm{~m}$, either a hard or rocky bottom requires SCUBA diving visual surveys as well as video imagery using Remote Operated Vehicles (ROVs); for a 10-800 m depth, soft bottoms and places with mounts and slopes are surveyed with ROV video and trawling; and for $800 \mathrm{~m}$ or more depths, pole trawling and ROV video can still address both soft and hard bottoms (Spengler and Costa, 2008; Cheshire et al., 2009; Galgani et al., 2013). Additionally, it has been delineated that ROVs have the same efficiency and depth recommendations in other types of floors such as continental slopes, canyon heads and uneven terrain (i.e., canyon floors, canyon flanks), with the exception of interchanging collection methodologies and sampling units. The construction of transect routes across canyon scenarios, which requires intensive image recording and other parameters (i.e., navigation logs, distance, time, depth, geographic position), allows for the analysis of overall floor morphology, and thus, density-based (i.e., items/area) ROV surveys using a laser pointer scale for field-of-vision width or numerical-based quantification (i.e., items/distance) (GESAMP, 2019).

It is important to mention that the rate that plastic litter accumulates at the seafloor depends on the source and the manifestation of retrieval practices. Therefore, monitoring programs, surveys, and observations (i.e., biodiversity assessments, marine reserve practices, offshore platforms) benefit from sampling at different timescales and frequencies, keeping ecosystemic specific records (i.e., bottom type, habitat, turbidity), especially in deep sea floor bottoms, and maintaining consistency of data with regards to particle classification and quantification (i.e., litter category, size, subclassification, point source, abundance, density as items/area, chemical typology, species endangerment) (Mordecai et al., 2011; Buhl-Mortensen and Buhl-Mortensen, 2017; GESAMP, 2019). Once the practice of ROV or Autonomous Underwater Vehicles (AUV) surveys is mastered, with models that can operate at different depths (i.e., 
Ventana $-1,850 \mathrm{~m}$, Tiburon and Doc Ricketts $-4,000 \mathrm{~m}$ ) and with the enhancement of acoustic resonance tools for the detection of derelict traps, methods for the compilation of data may aid large spatial scale monitoring may be realized. This may include harmonized monitoring betwen coastal institutions across a basin (i.e., northern Mediterranean Sea), the implementation of preliminary statistical power analysis to assess sampling design robustness, or the determination of plastic pollution in higher priority sites, such as the Monterey Canyon in California which has 12 years of observational data on the distribution and relative frequency of marine litter (Clark et al., 2013; Schlining et al., 2013; Loakeimidis et al., 2015; Tekman et al., 2017; Chiba et al., 2018; Fulton et al., 2018; Spedicato et al., 2020).

Other oceanographic processes that affect the vertical distribution of the full spectrum of plastic debris (i.e., microplastics, nanoplastics) (Galgani et al., 2000, 2011) include dense shelf water cascading, coastal storms, offshore convection and saline subduction (Talley, 2002; Ivanov et al., 2004; SanchezVidal et al., 2012; Durrieu de Madron et al., 2013). Nevertheless, the relative quantification of zooplankton and fish larvae, and density distribution and spatial variation of microplastics (e.g., hard, soft, threads, paint chips) has been studied in water columns of the Guiana Estuary, revealing their influence on bioavailability as well as trophic transfer according to rain season, the river basin, and fisheries activities (Lima et al., 2014). In addition to these anthropogenic activities among other phenomena (i.e., depth, location, habitat, urbanization), the topographic activity of submarine canyons (e.g., Santa Monica Bay in California) and features of seamounts (i.e., Taylor columns) might magnify the retention of microplastics and nanoplastics via downwelling flows by acting as deep-sea sinks in the future (Galgani et al., 1995; Galgani et al.,1996; Canals et al., 2006; White et al., 2007; Canals et al., 2013).

The development of spatial distribution simulations takes into an account a variety of data that has been compiled over the past decades. Examples of these variations include the accumulation of macro-debris along strandlines on Cliffwood beach in New Jersey (Thornton and Jackson, 1998); the progressive loss of sunken micro-debris at the North Pacific Ocean (Shaw and Day, 1994); the presence of fragmented micro-debris at the seafloor level in European coasts and enclosed gulfs of the Mediterranean Sea (Stefatos et al.,1999; Galgani, 2000); the subsequent behavior of plastic debris in response to wind trends at 10 pocket beaches in the southern Caribbean (Debrot et al.,1999); the influence of tidal dynamics on litter re-circulation and retrieval at a pocket beach in the Tresillian Bay of 
South Wales (Williams and Tudor, 2001); the spatial distribution and fouling biota composition (i.e., mobile species, suspension-feeders, species with sexual reproduction) of 34 buoys across the $45 \mathrm{~km}$ Bay System of Coquimbo in the South Pacific Ocean (Astudillo et al., 2009); the densities of floating plastic debris near and off-shore of the Chilean coast at the South Pacific Ocean (Thiel et al., 2003); as well as the surface drift of floating debris generated by a variety of phenomena (i.e. climatic forcing, geostrophic winds, stratospheric temperature, Coriolis effects) in the north of Hawaii and South Pacific subtropical gyre (Kubota, 1994; Martinez et al., 2009).

\subsection{Physico-chemical properties}

The sorption of chemical pollutants by microplastics exacerbates the biohazards in aquatic habitats of contaminated ecosystems (Kershaw et al., 2011; Antunes et al., 2013; Rochman et al., 2013; Rochman et al., 2014b). In addition to chemicals added during manufacturing (i.e., PCBs, PAHs, petroleum hydrocarbons, PBDEs, alkylphenols, and BPA), plastic debris (i.e., resin pellets, microfragments) have been extensively reported as contaminated with toxicants already existing in the marine environment in the order of $\mathrm{ng} / \mathrm{g}$ and $\mu \mathrm{g} / \mathrm{g}$ (e.g., organochlorine pesticides, OCPs) (Spitz, 1985; Mato et al., 2001; Moore et al., 2005; Teuten et al., 2009; Mizukawa et al., 2013; Gong, 2017). The presence of these and other endocrine-disrupting compounds (i.e., octylphenol, estrone, oestradiol, oestriol) is of great concern, particularly for nonylphenol and BPA as they have been found at concentrations ranging from 100-10,000 $\mu \mathrm{g} / \mathrm{L}$ in waste disposal leachates from Asia (Teuten et al., 2009). It has been systematically proven that the presence of PCBs (e.g., Aroclor 1254, a PCB mixture) and plasticizers, in combination with low oxygen concentrations and already existent pollutants in the environment (i.e., pesticides, surfactants, heavy metals), has a direct endocrine-disrupting effect in the human hypothalamic serotonergic pathway (i.e., 5-hydroxytryptamine) as well as in other terrestrials and marine organisms (Thomas et al., 2007; Gore, 2008, 2010; Rahman et al., 2011, 2020). In contrast, polymers such as silicone rubbers, polyoxymethylene (POM) and LDPEs have been used in laboratory tests as passive samplers (i.e., not a vector for contamination) with induced as weekly or monthly HOC equilibrium states (Jonker and Koelmans, 2001; Rusina et al., 2010; Lohmann, 2015). 
Ecosystemic interactions with manufactured nanomaterials (MNMs) have been shown to impair nutrient cycling, water depuration, and biomass production (Navarro et al., 2008). MNMs can also decrease light availability and gas exchange for photosynthesis due to their adsorption/deposition onto photosynthetically active surfaces (Navarro et al., 2008). Quality studies with ecotoxicological focus requires the synthesis of computational quantum-based approaches, extensive in vitro testing, and an efficient application of nascent (e.g., organic matter, colloidal inorganic species) and incidental (e.g., anthropogenic nanomaterial waste) particle physico-chemical properties within an effect-directed analysis (EDA) workflow (Lynch et al., 2014; Gallampois et al., 2015; Soni et al., 2015). In eco-neurotoxicity assessment, as a means for prioritizing environmental signals, the incorporation of toxicological effects and in silico identification statistics in chemical analysis can be approached by using multicriteria identification strategies (e.g., structure elucidation, ionization efficiency, fragmentation interpretation, linear solvation energy, mutagenicity prediction) on cheminformatic toolkits such as ChemSpider or MetFrag Scoring (Gallampois et al., 2015; Ruttkies et al., 2016). As is, quantitative nanostructure-activity relationship (QNAR) models have been used as computational methods to predict possible interactions of physico-chemical descriptors (i.e., principal component analysis: engineered size, agglomerated size in water, zeta potential, age of suspension, oxidant production) with living systems in the environment (Chau and Yap, 2012; Westerhoff and Nowack, 2013; Lynch et al., 2014).

In aquatic ecosystems with varying ionic strength and organic matter content, the physicochemical properties of MNM particles (i.e., chemical composition/coating: cationic polymer poly-L-lysine; surface charge: poly[vinyl alcohol-co-vinyl acetate-co-itaconic acid], aminosilane modification) and their dynamic state (i.e., functionalized: hydrophilicity and colloidal stability via acidic groups; polymer matrix binding/release: charge heterogeneity, hydrodynamic shear, steric repulsive force) dictate their flow-like behavior as aggregates. Thus, the delineation of ecotoxicological routes for MNMs such as transport potential and fate under hydrodynamic conditions elucidate likelihood of exposure (Keller et al., 2010; Petosa and Jaisi, 2010; Selck et al., 2016). As part of toxicity assessment in EDA workflow (i.e., target/non-target chemical analysis, bioassay confirmation), environmental samples can undergo fractionation and bio-testing to eliminate isolates without biological activity (Brack et al., 2016). Bio-testing techniques implemented on BFR-induced in vitro neurotoxicity environmental matrices include cell-based 
assays and liquid/gas chromatography coupled with mass spectroscopy (LC/GC-MS) (Qu et al., 2011). In addition, other high-throughput techniques (e.g., HPLC: gas-segmented enzyme inhibition, on-line coupled UV/Mass Spectrometric/Biochemical Detection) and organism-level methods (e.g., zebrafish embryos, plant extracts) have been used in EDA studies to identify neurotoxic chemicals (e.g., anticonvulsant drugs, toxins) or biochemical interactions (e.g., AChE inhibitors) (Ingkaninan et al., 2000; Fabel et al., 2005; Buenafe et al., 2013; Di Paolo et al., 2015; Orellana-Paucar et al., 2012). This data compilation is relevant in the field of nanotoxicology as toxicity parameters (i.e., no observed effect concentration -NOEC, least observed effect concentration -LOEC, minimum inhibitory concentration -MIC, lethal concentration $50 \%-\mathrm{LC}_{50}$, lethal dose $50 \%-\mathrm{LD}_{50}$ ) are confirmed in mammalian cell lines (Garner and Keller, 2014). These neurotoxicity endpoints can be correlated with the statistical approach of QNAR models in a biochemical context (i.e., contaminant-environment/ enzyme-toxicant interactions) and at the molecular level prior to extensive EDA analysis to potentiate novel virtual fractionations (Brack et al., 2016). Moreover, metabolite- and enzyme-based (i.e., cytochrome P450) detoxification mechanisms in phase I/II biotransformation pathways (e.g., AChE inhibitor elimination) would complement the high priority research category of complex subcellular-ecosystemic interactions as per the US Research Strategy for EHS Aspects of Engineered Nanomaterials (NRC, 2012; Legradi et al., 2018).

In experimental comparisons supported by mathematical models (i.e., equilibrium partitioning), PE fragments are more prone to adsorb hydrophobic contaminants than PPs and PVC plastics, and transition the particles onto organisms (Teuten et al., 2009; Rios et al., 2010; Ziccardi et al., 2016). This particular quality of PE compared to other plastic materials (e.g., PP, PS, PVC) is reflected by the high partition and distribution coefficients with certain hydrophobic organic chemicals (HOCs) (e.g., phenanthrene: $\log K_{\mathrm{f}}=4.93-10.43, K_{\mathrm{d}}=38,100 \pm 5,600$ ), which increases particle surface area and affinity as exposure to photo-weathering and photo-oxidation increases (Teuten et al., 2007; Ziccardi et al., 2016). Among these HOCs, other compounds that have raised concern due to their potential as transmission vectors through microplastics or for the protection of aquatic environments and organisms include OCPs and PAHs (Rios et al., 2007; Engler, 2012). Furthermore, plasticizers together with constitutional monomers and additives (i.e., PCBs, BPA), which are bio-persistent as they favor noncovalent bonds (i.e., intermolecular interactions, molecular electrostatic potentials, van der Waals 
bonding, hydrogen abstraction), have been found to leach through groundwater in municipal waste disposal sites, and therefore, into the terrestrial environment (Murray et al., 1994; Endo et al., 2005; Teuten et al., 2009; Yousif and Haddad, 2013; Velzeboer et al., 2014; Andrady, 2015; Lohman, 2015; Murray and Politzer, 2017). Based on the chemical structure of planar PCB congeners (e.g., PCB77, PCB153, PCB156), lateral non-ortho chlorine atom substitutions promote the binding of hydrogen atoms. Thus, biodegradation resistance is increased and endocrine-disrupting properties, neurotoxicity, and reproductive impairment has been demonstrated in Atlantic croaker, Micropogonias undulatus, in which a low dose ( $2 \mu \mathrm{g} / \mathrm{g}$ body weight) 4-week exposure to PCB77 induces neural death, alters gene expression of hepatic cytochrome P450 (CYP1A), aryl hydrocarbon receptor nuclear translocator (ARNT-1, ARNT-2), cytokine (e.g., interlukin-1 $\beta$ ), and oxidative stress (e.g., protein carbonyl contents, an indirect measure of ROS) (Stegeman and Lech, 1991; Rahman and Thomas, 2018, 2019; Rahman et al., 2020). HOCs have been reported in environmental concentrations ranging from $\mathrm{ng} / \mathrm{g}$ to $\mathrm{mg} / \mathrm{g}$, with concentrations varying drastically depending on their association with different microplastic particles and the environmental samples they constitute. This describes a rational differential assessment and identification of polymers prior to risk assessment or ecotoxicological designations (Ogata et al., 2009; Rochman et al., 2013). Among the abundant types of plastic (i.e., PE, PP, PS, PVC) highly contaminated with PCBs, DDT and dichlorodiphenyldichloroethylene (DDE) that have been identified in municipal solid waste are oil- and petrochemical-based packaging polymer forms (i.e., acenaphthene, fluorene, fluoranthene, anthracene, pyrene, phenanthrene), which also have been independently documented in several toxicological chemistry studies with high polymer-to-water partitioning coefficients that correlate to high octanol-water partition coefficient models (i.e., logKPSsw range = 3.62-5.84) (Mato et al., 2001; Teuten et al., 2007; Smedes et al., 2009; Lee et al., 2013; Bakir et al., 2014a; Lohmann, 2015). This particular quality gives these polymers a high sorptive capacity in water and sediment samples as well as their nonbiodegradable status, which makes them unable to be recycled or composted (Song et al., 2009; Ghosh et al., 2013; Lee et al., 2013). However, research on biopolymers with a high degree of biodegradability has been conducted in controlled composting system conditions in order to develop generic impact assessments and improve post-consumer waste management (Song et al., 2009). 
Although the sorption and desorption of contaminants to and from microplastics has been shown in a variety of terrestrial and aquatic organisms, the co-existence of physico-chemical properties and environmental parameters results in a dynamic relationship as opposed to a predictable progression. An analysis of continental shelf sediment cores contaminated up to $30.2 \%$ by plastic wieght ( $85 \%$ PE fragments by weight) found them to significantly change their physical properties (i.e., permeability, thermal diffusivity, heat capacity), and thus, increase their potential to affect the temperature-dependent sex-determination of certain organisms (e.g., sea turtle eggs) (Carson et al., 2011; Fisner et al., 2013). In an effort to assess the short-term toxicity of PAHs contaminated with PE microspheres, co-exposure of the common goby fish ( $P$. microps) revealed a significant increase in neurotoxin-induced mortality due to the accumulation of bile pyrene metabolites as well as decreased isocitrate dehydrogenase and acetylcholinesterase activity (Oliveira et al., 2013).

In contrast to direct biological effects, an experiment with lugworms ( $A$. marina) by Browne et al. (2013) demonstrated that contaminants (e.g., nonylphenol, phenanthrene) were more readily sorbed into tissues alone than via pre-sorbed PVC microparticles. Moreover, the bioconcentration of pre-sorbed microplastics with the additive PBDE and the biocide triclosan was analogous in lugworm tissues, however, when exposed to contaminated sediments in the absence of microplastics, these bioaccumulated at a larger weight (>250\%). Another experiment that utilized PCBs to expose blackworms (Lumbriculus variegatus) with and without PP particles reported a $76 \%$ decrease in PCB uptake in worms exposed to plastic-free sediments. However, the uptake of dechlorinated PCBs was higher in this case and this phenomenon was attributed to the size-associated (i.e., PP powder, diameter: $35 \mu \mathrm{m}$ ) kinetic limitation of PCBs when solubilized. In other words, the higher the particle size the lower its diffusion capacity during digestion (Beckingham and Ghosh, 2011). In the case of PE microplastic particles, the physico-chemical property of high sorption affinity (i.e., selective association) creates a fugacity gradient in the gut of organisms (e.g., fish, lugworms) and therefore limits the bioaccumulation of substances (e.g., nonylphenol, bisphenol A, HOCs, PCBs) that are otherwise classified as ubiquitous and toxic, by as much as $80 \%$ (Koelmans et al., 2013). Moreover, the presence of natural organic carbon in a greater proportion $\left(1.26 \times 10^{7}\right.$-fold) than that of plastics within marine coastal environments, as well as plankton, dissolved 
organic matter, and pre-existing physiological conditions, greatly influences this outcome (Gouin et al., 2011; Ghosh et al., 2014; Lima et al., 2014; Lima et al., 2014; Herzke et al., 2016; Koelmans et al., 2016).

According to a PS microparticle exposure model with the lugworm, A. marina, that uses PCB congeners and sediment as variable parameters, there are two mechanisms in which chemicals are diluted: (1) the closed system with high microplastic concentrations (i.e., laboratory tests, field enclosures), and (2) the open system (i.e., oceanic systems) with marginal effects due to readily diluted microplastics (Gouin et al., 2011; Besseling et al., 2013). Assuming a transient state, as opposed to a steady-state system, POPs sorbed into microplastic particles undergo a reversible exchange with biota lipids that depends on the ingestion amount, the established gradient between the rate of concentrations, and the amount of POPs desorbed from microplastic particles (Koelmans et al., 2013). In the case of PCBs, a closed system is affected as the microplastic concentration increases and the initial contaminants are adsorbed due to the high affinity of the congeners (i.e., dilution mechanism) (Teuten et al., 2007; Browne et al., 2013). Furthermore, the adsorption and desorption efficiency of the aforementioned transient state bifurcates into two additional sub-mechanisms, governed entirely by the lipid-plastic partition coefficient (KPLIP): the carrier mechanism (i.e., KPLIP $=1$ ) when the mass transfer is from plastics to lipids at higher plastic concentrations, and the cleaning mechanism (i.e., KPLIP $=-1$ ) when the mass exchange is reversed and the organism is completely depurated of POPs (Koelmans et al., 2013). It is important to mention that the average gut residence time variable is imperative for lugworms in this model, as the segmented gut of lungworms has the potential to yield distinct kinetics for contaminants in sediment (Chen and Mayer, 1999). Parameters that affect average gut residence time are gut volume (i.e., radius, length, worm wet weight) and the volumetric flow rate of the ingested particles (i.e., average sediment-plastic density), which decreases with an increasing plastic-to-sediment ratio (Janssen et al., 2010). The results of this model for the congener PCB105 determined that its bioconcentration in lugworm tissues marginally increases after 28 days with increasing PS exposure (i.e., $7.4 \%>0.074 \%>$ $0.74 \%$ ). A plateau is reached at $\sim 1.2 \mu \mathrm{g} / \mathrm{kg}$ of lugworm dry weight, and the absorption efficiency of the congener switches from positive (carrier mechanism) to a cleaning mechanism resulting in decreased bioaccumulation after 5 days. An average gut residence time of $43 \mathrm{~min}$ in this species is in accordance with a model for the polychaete, Neanthes arenaceodentata (Janssen et al., 2010; Koelmans et al., 
2013). Ecotoxicology studies have begun to implement the use of closed systems that resemble field enclosures with high microplastic concentrations to perform passive dosing. These nonequilibrium tests allow for the determination and quantification of toxicity parameters at the aqueous phase in the gut of organisms, while regarding alternative pathways (e.g., water, food) as negligible (Bakir et al., 2014b; Rochman et al., 2014b; Claessens et al., 2015; Herzke et al., 2016).

\subsection{Leaching chemicals}

An additional risk of microplastic in afflicted marine environments and aquatic organisms is the potential of PE- and PS-derived microplastic particles to adsorption and leach chemical toxicants (e.g., pyrene) (Avio et al., 2015). Since meso-, micro-, and nano-plastic debris consist of hydrophobic particles with electrically charged biofilms (i.e., ionic bond interactions), their life cycle depends on the absorption and desorption of already present contaminants in the medium (i.e., POPs, pesticides, heavy metals), varying environmental conditions such as local $\mathrm{pH}$ variation, bacterial cell adhesion, and nutrient availability in the aquatic environment (i.e., freshwater, brackish water, marine) (Ponsonnet et al., 2008; Heskett et al., 2012; Janjaroen et al., 2013; Liao et al., 2015; Koelmans et al., 2017; Harrison et al., 2018). Conjugated microplastics associate with PAHs, increasing their bioavailability, and are more likely to be deposited into organisms (e.g., mussels) with detrimental effects at the cellular (e.g., immunological response, antioxidant system, neurotoxicity, etc.) and molecular levels (e.g., lysosomal compartment, peroxisomal proliferation, genotoxicity) (Avio et al., 2015). Furthermore, PBDEs, which are halogenated aromatic compounds (HACs), have been shown to biodegrade at the nanoscale (i.e., zerovalent iron based bimetallic systems) in two dominant debromination pathways via electron (para-bromine substitution) and hydrogen atom (ortho-bromine substitution) transfer mechanisms (Pettigrew, 1993; Zhuang et al., 2010; Liu et al., 2015; Wang et al., 2015; Wang et al., 2019) (Fig. 2). Depending on the surrounding trace element (i.e., $\mathrm{Fe}, \mathrm{Cu}$ ) concentrations in oceanic, coastal, estuarine or river waters, heavy metals (e.g., $\mathrm{Hg}, \mathrm{Cd}$ ) as well as other toxicants (e.g., Ag, Pd, Pt) can interact with PBDEs in microplastic pollutants and stimulate the aforementioned biodegradation pathways when they enter environmental biotic (i.e., biosphere) and abiotic (i.e., lithosphere, atmosphere, hydrosphere) biogeochemical cycles (i.e., industrial catalysis, automotive industry, anti-cancer medical applications) (González García et al., 2003; Cwiertny et al., 2007; Rauch and Morrison, 2008; Gallon and Flegal, 2015; 
Stefaniuk et al., 2016; Fischer et al., 2018). Additionally, secondary microplastics that are fragmented via mechanical abrasion and exposure to UV radiation undergo further biodegradation via photolysis, photooxidative and/or thermo-oxidative pathways in the environment (i.e. sediment, soil, sand, metal oxides, clay minerals, water, water/organic mixtures, house dust, textiles, electronic products, automobile dust), and studies have elucidated the photodebromination mechanisms by which several congeners of PBDEs convert to polybrominated dibenzofurans (PBDFs) depending on their lowest unoccupied molecular orbital (LUMO, Supplementary Table 2), especially in surfactant solutions (Watanabe et al., 1987; Eriksson et al., 2004; Rayne Wan and Ikonomou, 2006; Li et al., 2008; Song et al., 2015; Wang et al., 2018). Natural (e.g., dioxins) as well as anthropogenic contaminants (e.g., PCBs, organo-halogenated pesticides, nonylphenol, PAHs) have been identified at plastic-contaminated beaches around the globe (Hirai et al., 2011; Heskett et al., 2012), and have been shown to distribute thermodynamically as well as physiologically in the gut of different organisms (Tanaka et al., 2013; Bakir et al., 2014a).

Aside from the common ingestion route of microplastics (i.e., water, sediments, food) and trophic transfer into humans, laboratory models with varying experimental conditions have demonstrated that HOCs can be transferred from organisms to microplastics (Ziccardi et al., 2016). The characterization of the adsorption and release of these hydrophobic chemicals, as well as their bioaccumulation and biological effects, has been assessed in the feeding mussel, M. galloprovincialis, for simultaneous exposure of PE and PS with pyrene, a common PAH that sorbs to marine debris (Rios et al., 2007; Avio et al., 2015). The evaluation of molecular mechanisms of action (MOA), weight of evidence (WOE) and different lines of evidence (LOEs) allow for a multidisciplinary approach to examine the effects of microplastics using tissue localization, pyrene bioaccumulation, cellular biomarkers, immunological parameters, genotoxicity, and DNA microarray-based transcriptomics (Chapman et al., 2002; Chapman, 2007). The establishment of these parameters as developed by mathematical algorithms has led to an integrated ecological risk assessment (ERA), which aids in the preliminary steps (e.g. sediment chemistry, pollutant bioavailability, level of biological organization) towards understanding ecotoxicological effects and optimizing risk assessments in the future (i.e., water body ecological status classification) (Piva et al., 2011; Benedetti et al., 2012). 
Another example of this ecological approach implemented a mathematical model based on open ocean simulations (i.e., dilution of exposure concentration, ingestion of contaminated and clean fragments) to analyze micro-PSs, micro-PEs and nanoplastics as bioaccumulation and biomagnification vectors of POPs in lugworms (Koelmans et al., 2013). A contrasting meta-analysis study suggests that the HOC microplastic-water partitioning is at equilibrium (i.e., sorbed or ingested) in the oceans, further proving that polymers are desorbed in gut fluids, and that trophic transfer is more hazardous than ingestion of microplastics and subsequent absorption of HOCs (Koelmans et al., 2016). A key element of the WOE approach is the relevance of biomarkers in accordance to their biological endpoints in a specific bioindicator organism. This relationship can be established as the ratio of response variations (i.e., induction, inhibition) of a given biomarker to that of its threshold, which is normalized to the particular weight given to the biomarker in order to identify statistical significance when compared to controls (Piva et al., 2011). Thus, according to the Hazard Quotient for biomarkers formula, whose results can be categorized into one of 5 classes (i.e., absent, slight, moderate, major, severe), ratios 2 -fold above the threshold are considered hazardous, whereas, lower or equal than threshold are dismissed:

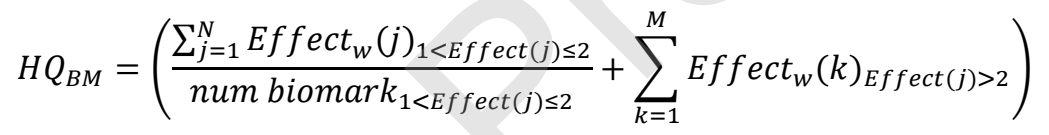

According to this formula by Avio et al. (2015), the tissue bioaccumulation threshold of biomarkers $\left(H Q_{B M}>2.6\right.$ fold; Moderate) is established with the WOE model (LOE2; Absent $\rightarrow$ Slight $=2.6$ fold, Moderate $=2 \cdot 6-6.5$-fold, Major $=6.5-13$-fold, Severe $=>13$-fold). The toxicological relevance of the WOE model indicates the hazard level of cellular responses (Slight $\rightarrow$ Moderate), which were higher for contaminated-PS compared to -PE. Given the bioavailability of pyrene classified as Severe, cellular/subcellular and genetic expression alterations for Severe WOE (LOE3) were also established under chronic exposure conditions ( $\geq 7$ days) to contaminated (low $=0.5 \mu \mathrm{g} / \mathrm{L}$, med $=5 \mu \mathrm{g} / \mathrm{L}$, high $=50$ $\mu \mathrm{g} / \mathrm{L}) \mathrm{PE}$ and PS microplastics ( $<100 \mu \mathrm{m} ; 20 \mathrm{~g} / \mathrm{L})$. The $H Q_{B M}$ formula calculates the average of Moderate responses, and then adds the summation of responses that are Major or Severe. As is, measured variations are compared to thresholds, the weight of the biomarker, and then by comparing to controls statistical significance is performed. For LOE2, significant pyrene bioaccumulation was found in gill and digestive gland tissues. Furthermore, microparticles as well as aggregates were identified in several 
cellular compartments (i.e. intestinal lumen, epithelium, tubules) of digestive gland tissue using histological analyses. DNA strand breaks and nuclear anomalies (i.e., micronuclei) were also identified in polymer-exposed (i.e., virgin, contaminated) haemocytes using the comet assay, and DNA repair genes were modulated (i.e., growth arrest -GADD45A, DNA-damage-inducible protein -GADD45G). In addition, the following differentially expressed genes (DEGs) were identified using functional annotation and enrichment analysis: apoptosis (downregulated genes: BAXA, CASP3A, PRKAR2AA, BIRC2; upregulated genes: DFFB, BIRC7, CASP9, NFKBIAB, BCL2L1, MYD88), regulation of programmed cell death (downregulated genes: CASP3A, BAXA, TRAF3, BIRC2, CASP9, CCT3; upregulated genes: CASP2, BCL2L1, CRADD, CASP2, MCL1B, TRAF6). The toxicological potential of microplastics on KEGG pathways (WOE approach) can be further integrated to derive a comprehensive (e.g., physical, chemical, biological, ecological) risk assessment analysis.

Molecular Initiating Events (MIEs), effects related to the association of compounds and their corresponding molecular targets, have different biological organizations, and trigger adverse outcome pathways (AOPs) in need of regulation (Legradi et al., 2018). HQ assessment is an approach that has been used to prioritize neuroactivity or neurotoxicity AOPs of major interest in ecotoxicology, and the establishment of high $H Q$ compound MIEs allows further ranking of AOPs; compounds with high $H_{\text {Log }}$ that approach zero indicate that environmental concentrations are likely to cause a biological effect (Legradi et al., 2018). Ranked by environmental relevance, compounds with mechanisms of neuroactivity include acetylcholinesterase inhibitors (e.g., triphenylphosphate, rivastigmine, tris(1,3-dichloroisopropyl) phosphate, GABA receptor antagonists (e.g., Fipronil), serotonin reuptake inhibitors (e.g., N,Odidesmethyl venlafaxine, citalopram, O-desmethylenlafaxine, venlafaxine), and nicotinic acetylcholine receptor agonists (e.g., thiacloprid, acetamiprid, imidacloprid) (Legradi et al., 2018). Future toxicity studies can replicate these parameters with several plastic materials, and assess the fate, impact, and risk of these under ecotoxicological challenge phases (i.e., dose-dependent: non-observable adverse effect limit; qPCR-based bacterial quantification; GUTS models: critical body residue, damage assessment model, dynamic energy budget model, general unified threshold model for survival, threshold damage model, toxicokinetic) and scales (i.e., microbiome-aware: gut-associated community resistance and resiliency; 
metatranscriptomic/metaproteomic approach; MetaFISH: metabolite imaging/bacterial genotype) (Jager and Ashauer, 2018; Duperron et al., 2020).

\section{Ecotoxicological prospect: optimized impact assessment}

Despite the known phenomena of ingestion and bioaccumulation of microplastics in marine organisms, species-specific evidence of the desorption of additives and other toxicants from these plastic particles for a given ecological niche is still lacking (Bakir et al., 2012, 2014a; Engler, 2012). This poses a problem for the development of relevant laboratory studies with ecotoxicological challenge for marine organisms, dealing with plastic polymer typologies (e.g., equilibrium kinetics, partition coefficients) and hydrophobic chemicals (Lee et al., 2013; Bakir et al., 2014b). Nevertheless, efforts have been made to establish ecologically relevant metrics (ERMs) for risk assessment frameworks related to nano- and micro-plastic pollution in particular ecosystem compartments (Koelmans et al., 2017). Additionally, the primary objective of ERMs is to consider the indirect relationship of biological effects that occur above environmentally realistic threshold concentrations (Lenz et al., 2016). Further characterization of established ERMs by the tissue-specific and cellular toxicity effects elicited by specific chemicals are known as adverse outcome pathways (AOPs) (Koelmans et al., 2017).

For a given ecosystem, while concentration based ERMs are sufficient for risk assessments, protection goals can be enhanced by accurate characterizations based on monitoring and the mechanistic behavior of microplastics in water bodies (Koelmans et al., 2017). Contrary to current scientific opinions, there is growing evidence from laboratory experiments that examines biological effects induced by unrealistic chemical exposure, which leads to artificial conclusions, thus, a critical review of the metrics used to quantify ecologically relevant and laboratory exposures ought to be strictly implemented for toxicological studies (Koelmans et al., 2013; Lohmann, 2015; Koelmans et al., 2017). Furthermore, laboratory studies are often performed within a controlled environment that does not integrate the mixture of chemicals of a given ecosystem nor the community of organisms that co-exist within it. This poses a challenge to already existing response addition models as well as dynamic energy budget models (Altenburger et al., 2003; Filgueira et al., 2011; Posthuma et al., 2018). Once these challenges are met, protection goals ought to be developed based on nanoplastic ERMs that elucidate 
retention parameters in freshwater/marine ecosystems and water treatment plants, in addition to mechanism of biodegradation pathways (i.e., dilution, aggregation, fouling, sinking) (Koelmans et al., 2017).

Once response addition models acquire concentration-based ERMs and AOPs, the fate and exposure of plastic debris can be simulated in geographical interpolations (e.g., freshwater catchments, ocean) with optimized spatio-temporal parameters (Besseling et al., 2017; Hardesty et al., 2017; Kooi et al., 2017). For example, the parameter of inhaled airborne nanoplastic particles cannot be mutually exclusive to other airborne contaminants (e.g., soot, black carbon) (Wiesner et al., 2011; Wang et al., 2014; Verschoor et al., 2016). In ecotoxicology models, which merge concentration-based ERMs and AOP-based chemical risk assessments (i.e., $\mathrm{LC}_{50}, \mathrm{EC}_{50}$ ), the statistical rigor of thresholds established by progressive plastic fragmentation (e.g., physico-chemical/thermal degradation) is still needed and requires well-established criteria for environmental chemistry parameters prior to toxicity assessments, which in turn pose a demand for higher quality research related to microplastics (Klimisch et al.,1997; Moermond et al., 2016). These parameters also pose further challenges for the development of ecosystemic-based approaches as chemical risk assessment practice relies primarily on rational analysis and might exclude the affinity and characterization of a variety of biological responses (Connors et al., 2017). Moreover, studies of ERMs and AOPs are extended in response addition models with the coexistence of a variety of organisms (i.e., species sensitivity distribution) and stressor particles (Garner et al., 2015). An ecosystemic approach to integrated impact assessment design should include concentration based ERMs with a clear meta-analysis in the bifurcation of thresholds of physical (e.g., progressive fragmentation) as well as chemical (e.g., biodegradation pathways) AOPs (Koelmans et al., 2017).

\section{Conclusion}

Upon the introduction of HDPEs and LDPEs in the 1920s, and reported distribution in the environment during 1993, plastic accumulation in landfills developed a feedback loop mechanism in urban areas, coastal areas, and ocean gyres around the globe. As such, species inhabiting these terrestrial and aquatic ecosystems faced gradual exposure to fragmented particles with the capacity to 
induce toxicity as well as ingestion- and entanglement-related problems. Microplastic sinking results in marine aggregates, with differing suspended particle motion and further fragmentation at the nanoscale, that affect marine as well as freshwater biota upon egestion and metabolization. A recurrent issue that ecosystems face is the trophic transfer of microfibers, which occur at distinct ingestion rates across taxa and within different marine zones, and result in direct biological effects compared to their non-fiber counterparts. The size and shape of these microfibers and derived nanoparticles are strictly correlated to human health as they are metabolized, induce diseases, and alter biochemical pathways that lead to changes in gene expression. The trophic transfer of microplastics between terrestrial and marine species, clearly delineate ecological risks and, most importantly, an ecotoxicological potential that warrants further study. Although several governmental issues established by the UN (i.e., 2012 Global Partnership of Marine Litter, 2015 Sustainable Development Goals, 2017 Clean Seas Campaign, 2018 Global Plastics Platform, 2019 Plastic Leak Project, 2016-2019 Environment Assembly Resolutions on Marine Litter and Microplastics) have made an effort to develop scientific research and sustainable development areas, the implementation of new technology for the innovation of monitoring methods in the environment is still in progress. The potential for destabilized population dynamics due to the biological impact (i.e., impaired sperm/ova production, immune system) of organisms in terrestrial, freshwater, and marine ecosystems is reflected on the effects of global warming (i.e., heat-induced stress) and pollution (i.e., chemical-induced stress) on microplastics in water bodies.

\section{Funding}

Funding was not received from private and public institutions/sectors.

\section{Declaration of Competing Interest}

The authors declare that they have no known competing financial interests or personal relationships that could have appeared to influence the work reported in this review paper.

\section{Acknowledgments}


We would like to thank Dr. Aubrey Converse, University of Texas Marine Science Institute (UTMSI), and Andrew Lawler, Division of Research, Graduate Studies and New Program Development, and David Tran, University of Texas Rio Grandy Valley (UTRGV), for their valuable suggestions and critically reviewing the manuscript. We also thank Alexa Campos, Department of Biology, UTRGV for original drawings of seaweed and sea urchin egg in graphical abstract. Thanks are due as well to Stephanie DuBois, former UTRGV graduate student, and Md Imran Noor, Khulna University, Bangladesh, for providing the photographs depicted in this manuscript. We also thanks and greatly appreciate two anonymous reviewers for providing their constructive comments and valuable suggestions on the manuscript.

\section{References}

Alimba, C.G., Faggio, C., 2019. Microplastics in the marine environment: Current trends in environmental pollution and mechanisms of toxicological profile. Env. Toxicol. Pharmacol. 68, 61-74. https://doi.org/10.1016/j.etap.2019.03.001.

Altenburger, R., Nendza, M., Schüürmann, G., 2003. Mixture toxicity and its modeling by quantitative structure-activity relationships. Environ. Toxicol. Chem. 22(8), 1900-1915. https://doi.org/10.1897/01-386.

Andrady, A., 2015. Persistence of plastic litter in the oceans. Mar. Anthropogenic Litter, 29-56. https://doi.org/10.1007/978-3-319-16510-3_3.

Andrady, A.L., Neal, M.A., 2009. Applications and societal benefits of plastics. Philos. Trans. R. Soc. B. 364(1526), 1977-1984. https://doi.org/10.1098/rstb.2008.0304.

Antunes, J.C., Frias, J.G.L., Micaelo, A.C., Sobral, P., 2013. Resin pellets from beaches of the Portuguese coast and adsorbed persistent organic pollutants. Estua. Coast. Shelf Sci. 130, 6269. https://doi.org/10.1016/j.ecss.2013.06.016.

Astudillo, J.C., Bravo, M., Dumont, C.P., Thiel, M., 2009. Detached aquaculture buoysin the SE Pacific a potential dispersal vehicle for associated organisms. Aquat. Biol. 5, 219-231. https://doi.org/10.3354/ab00151. 
Auman, H.J., Ludwig, J.P., Giesy, J.P. Colborn, T., 1997. Surrey Beatty \& Sons: Albatross Biology and Conservation. Plastic ingestion by Laysan albatross chicks on Sand Island, Midway Atoll in 1994 and 1995. http://www.cosee.net/coseewest/October06Resources/Related\%20Articles/Plastic\%20ingestion\%20by\%20Laysan\%20Albatr oss\%20chicks\%20on\%20Midway\%20Atoll.pdf.

Avella, M., Bonadies, E., Martuscelli, E., Rimedio, R., 2001. European current standardization for plastic packaging recoverable through composting and biodegradation. Polym. Test., 20, 517-521. https://doi.org/10.1016/S0142-9418(00)00068-4.

Avio, C.G., Gorbi, S., Milan, M., Benedetti, M., Fattorini, D., d’Errico, G., Pauletto, M., Bargelloni, L., Regoli, F., 2015. Pollutants bioavailability and toxicological risk from microplastics to marine mussels. Environ. Pollut. 198, 211-222. https://doi.org/10.1016/j.envpol.2014.12.021.

Awara, W.M., El-Nabi, S.H., El-Gohary, M., 1998. Assessment of vinyl chloride-induced DNA damage in lymphocytes of plastic industry workers using a single-cell gel electrophoresis technique. Toxicol. 128 (1), 9-16. https://doi.org/10.1016/S0300-483X(98)00008-0.

Azzarello, M., Van Vleet, E., 1987. Marine birds and plastic pollution. Mar. Ecol. Prog. Ser. 37, 295-303. https://doi.org/10.3354/meps037295.

Baechler, B.R., Granek, E.F., Hunter, M.V., Conn, K.E., 2020. Microplastic concentrations in two Oregon bivalve species: Spatial, temporal, and species variability. Limnol. Oceanogr. Lett. 5 (1), 54-65. https://doi.org/10.1002/lol2.10124.

Bakir, A., Rowland, S.J., Thompson, R.C., 2012. Competitive sorption of persistent organic pollutants onto microplastics in the marine environment. Mar. Poll. Bull. 64(12), 2782-2789. https://doi.org/10.1016/j.marpolbul.2012.09.010.

Bakir, A., Rowland, S.J., Thompson, R.C., 2014a. Enhanced desorption of persistent organic pollutants from microplastics under simulated physiological conditions. Environ. Poll. 185, 16-23. https://doi.org/10.1016/j.envpol.2013.10.007

Bakir, A., Rowland, S.J., Thompson, R.C., 2014b. Transport of persistent organic pollutants by microplastics in estuarine conditions. Est. Coast. Shelf Sci. 140, 14-21. https://doi.org/10.1016/j.ecss.2014.01.004. 
Baldwin, A.K., Corsi, S.R., Mason, S.A., 2016. Plastic debris in 29 great lakes tributaries: relations to watershed attributes and hydrology. Environ. Sci. Technol. 50, 10377-10385. https://doi.org/10.1021/acs.est.6b02917.

Ballent, A., Corcoran, P.L., Madden, O., Helm, P.A., Longstaffe, F.J., 2016. Sources and sinks of microplastics in Canadian Lake Ontario nearshore, tributary and beach sediments. Mar. Pollut. Bull. 110, 383-395. https://doi.org/10.1016/j.marpolbull.2016.06.037.

Barletta, M., Lima, A.R.A., Costa, M.F. 2019. Distribution, sources and consequences of nutrients, persistent organic pollutants, metals and microplastics in South American estuaries. Sci. Total Environ. 651, 1119-1218. https://doi.org/10.1016/j.scitotenv.2018.09.276.

Barnes, D.K.A., Galgani, F., Thompson, R.C., Barlaz, M., 2009. Accumulation and fragmentation of plastic debris in global environments. Philos. Tran. R. Soc. B. 364(1526), 1985-1998. https://doi.org/10.1098/rstb.2008.0205.

Beckingham, B., Ghosh, U., 2011. Field-Scale Reduction of PCB bioavailability with activated carbon amendment to river sediments. Environ. Sci. Technol. 45(24), 10567-10574. https://doi.org/10.1021/es202218p.

Benedetti, M., Ciaprini, F., Piva, F., Onorati, F., Fattorini, D., Notti, A., Ausili, A., Regoli, F., 2012. A multidisciplinary weight of evidence approach toward polluted sediments: integrating sediment chemistry, bioavailability, biomarkers responses and bioassays. Environ. Int. 38, 17-28. https://doi.org/10.1016/j.envint.2011.08.003.

Bergmann, M, Gutow, L., Klages, M., 2015. Marine anthropogenic litter (p. 447). Springer Nature.

Besseling, E., Wang, B., Lürling, M., Koelmans, A.A., 2014. Nanoplastic affects growth of S. obliquus and reproduction of D. magna. Environ. Sci. Technol. 48(20), 12336-12343. https://doi.org/10.1021/es503001d.

Besseling, E., Wegner, A., Foekema, E.M., van den Heuvel-Greve, M.J., Koelmans, A.A., 2013. Effects of microplastic on fitness and PCB bioaccumulation by the lugworm Arenicola marina (L.). Environ. Sci. Technol. 47(1), 593-600. https://doi.org/10.1021/es302763x.

Besseling, E., Foekema, E.M., Van Franeker, J.A., Van Franeker, J.A., Lpold, M.F., Kuhn, S., Bravo Rebolledo, E.L., Hebe, E., Mielke, L., IJzer, J., Kamminga P., Koelmans, A.A., 2015. Microplastic 
in a macro filter feeder: Humpback whale Megaptera novaeangliae. Mar. Pollut. Bull. 95(1), 248252. https://doi.org/10.1016/j.marpolbul.2015.04.007.

Besseling, E., Quik, J.T.K., Sun, M., Koelmans, A.A., 2017. Fate of nano- and microplastic in freshwater systems: A modeling study. Environ. Pollut. 220, 540-548. https://doi.org/10.1016/j.envpol.2016.10.001.

Betts, K., 2008. Why small plastic particles may pose a big problem in the oceans. Environ. Sci. Technol. 42 (24), 8995-8995. https://doi.org/10.1021/es802970v.

Birch, Q.T., Potter, P.M., Pinto, P.X., Dionysiou, D.D., and Al-Abed, S.R., 2020. Sources, transport, measurement and impact of nano and microplastics in urban watersheds. Rev. Environ. Sci. Bio/Technol. 19, 275-336. https://doi.org/10.1007/s11157-020-09529-x.

Boerger, C.M., Lattin, G.L., Moore, S.L., Moore, C.J., 2010. Plastic ingestion by planktivorous fishes in the North Pacific Central Gyre. Mar. Pollut. Bull. 60(12), 2275-2278. https://doi.org/10.1016/j.marpolbul.2010.08.007.

Bouwmeester, H., Hollman, P.C.H., Peters, R.J.B., 2015. Potential health impact of environmentally released micro- and nanoplastics in the human food production chain: Experiences from nanotoxicology. Environ. Sci. Technol. 49(15), 8932-8947. https://doi.org/10.1021/acs.est.5b01090.

Brack, W., Ait-Aissa, S., Burgess, R.M., Busch, W., Creusot, N., Di Paolo, C., Escher, B.I., Hewitt, L.M., Hilscherova, K., Hollender, J., Hollert, H., Jonker, W., Kool, J., Lamoree, M., Muschket, M., Neumann, S., Rostkowski, P., Ruttkies, C., Schollee, J., Schymanski, E.L., Schulze, T., Seiler, TB., Tindall, A.J., De Aragão Umbuzeiro, G., Vrana, B, Krauss, M., 2016. Effect-directed analysis supporting monitoring of aquatic environments-an in-depth overview. Sci. Total Environ.. 544, 1073-1118. https://dx.doi.org/10.1016/j.scitotenv.2015.11.102.

Brandão, M.L., Braga, K.M., Luque, J.L., 2011. Marine debris ingestion by Magellanic penguins, Spheniscus magellanicus (Aves: Sphenisciformes), from the Brazilian coastal zone. Mar. Pollut. Bull. 62(10), 2246-2249. https://doi.org/10.1016/j.marpolbul.2011.07.016 
Brander, S.M., 2013. Thinking Outside the Box: Assessing Endocrine Disruption in Aquatic Life. In: Monitoring Water Quality (pp. 103-147). Elsevier, Amsterdam, Netherlands. https://doi.org/10.1016/B978-0-444-59395-5.00005-4

Bråte, I.L.N., Eidsvoll, D.P., Steindal, C.C., Thomas, K.V., 2016. Plastic ingestion by Atlantic cod (Gadus morhua) from the Norwegian coast. Mar. Pollut. Bull. 112(1-2), 105-110. https://doi.org/10.1016/j.marpolbul.2016.08.034.

Bravo Rebolledo, E.L., van Franeker, J.A., Jansen O.E., Rasseur, S.M., 2013. Plastic ingestion by harbour seals (Phoca vitulina) in The Netherlands. Mar. Poll. Bull. 67, 200-202. https://doi.org/10.1016/j.marpolbul.2012.11.035

Brennecke, D., Ferreira, E.C., Costa, T.M.M., Appel, D., da Gama, B.A.P., Lenz, M., 2015. Ingested microplastics $(>100 \mu \mathrm{m})$ are translocated to organs of the tropical fiddler crab Uca rapax. Mar. Pollut. Bull. 96(1-2), 491-495. https://doi.org/10.1016/j.marpolbul.2015.05.001.

Browne, M.A., Galloway, T., Thompson, R., 2007. Microplastic- an emerging contaminant of potential concern? Integr. Environ. Asses. 3(4), 559-561. https://doi.org/10.1002/ieam.5630030412.

Browne, M.A., Dissanayake, A., Galloway, T.S., Lowe, D.M., Thompson, R.C., 2008. Ingested microscopic plastic translocates to the circulatory system of the mussel, Mytilus edulis (L.). Environ. Sci. Technol. 42(13), 5026-5031. https://doi.org/10.1021/es800249a.

Browne, M.A., Galloway, T.S., Thompson, R.C., 2010. Spatial patterns of plastic debris along estuarine shorelines. Environ. Sci. Technol. 44(9), 3404-3409. https://doi.org/10.1021/es903784e.

Browne, M.A., Crump, P., Niven, S.J., Teuton, E., Tonkin, A., Galloway, T., Thompson, R.C., 2011. Accumulation of microplastic on shorelines worldwide: sources and sinks. Environ. Sci. Technol. 45, 9175-9179. https://doi.org/10.1021/es201811s.

Browne, M.A., Niven, S.J., Galloway, T.S., Rowland, S.J., Thompson, R.C., 2013. Microplastic moves pollutants and additives to worms, reducing functions linked to health and biodiversity. Curr. Biol. 23(23), 2388-2392. https://doi.org/10.1016/j.cub.2013.10.012.

Buenafe, O.E., Orellana-Paucar, A., Maes, J., Huang, H., Ying, X., De Borggraeve, W., Crawford, A.D., Luyten, W., Esguerra, C.V., de Witte, P., 2013. Transhinone IIA exhibits anticonvulsant activity in 
zebrafish and mouse seizure models. ACS Chem. Neurosci. 4, 1479-1487. https://10.1021/cn400140e.

Buhl-Mortensen, L., Buhl-Mortensen, P., 2017. Marine litter in the Nordic Seas: Distribution composition and abundance. Mar. Pollut. Bull. 125(1-2), 260-270.

https://doi.org/10.1016/j.marpolbul.2017.08.048

Cadée, G.C., 2002. Seabirds and floating plastic debris. Mar. Pollut. Bull. 44(11), 1294-1295. https://doi.org/10.1016/S0025-326X(02)00264-3.

Canals, M., Puig, P., de Madron, X. D., Heussner, S., Palanques, A., Fabres, J., 2006. Flushing submarine canyons. Nature 444, 354-357. https://doi.org/10.1038/nature05271.

Canals, M., Company, J.B., Martín, D., Sànchez-Vidal, A., Ramírez-Llodrà, E., 2013. Integrated study of Mediterranean deep canyons: Novel results and future challenges. Prog. Oceanography, 118, 127. https://doi.org/10.1016/j.pocean.2013.09.004.

Carbery, M., O'Connor, W., Palanisami, T., 2018. Trophic transfer of microplastics and mixed contaminants in the marine food web and implications for human health. Environ. Int. 115, 400409. https://doi.org/10.1016/j.envint.2018.03.007.

Carpenter, E.J., Smith, K.L., 1972. Plastics on the Sargasso sea surface. Science, 175(4027), 12401241. https://doi.org/10.1126/science.175.4027.1240.

Carpenter, E.J., Anderson, S.J., Harvey, G.R., Miklas, H.P., Peck, B.B., 1972. Polystyrene spherules in coastal waters. Science, 178(4062), 749-750. https://doi.org/10.1126/science.178.4062.749.

Carson, H.S., Colbert, S.L., Kaylor, M.J., McDermid, K.J., 2011. Small plastic debris changes water movement and heat transfer through beach sediments. Mar. Pollut. Bull. 62(8), 1708-1713. https://doi.org/10.1016/j.marpolbul.2011.05.032.

Carr, S.A., Liu, J., Tesoro, A.G., 2016. Transport and fate of microplastic particles in wastewater treatment plants. Water Res. 91, 174-182. https://doi.org/10.1016/j.watres.2016.01.002.

Cedervall, T., Hansson, L.A., Lard, M., Frohm, B., Linse, S., 2012. Food chain transport of nanoparticles affects behaviour and fat metabolism in fish. PLoS ONE, 7(2), e32254. https://doi:10.1371/journal.pone.0032254. 
Chae, Y., An, Y.J., 2018. Current research trends on plastic pollution and ecological impacts on the soil ecosystem: a review. Environ. Pollut. 240, 387-395. https://doi.org/10.1016/j.envpol.2018.05.008.

Chakrabarti, P., Ghosh, S., 2014. A comparative study of the histology and microanatomy of the stomach in Mystus vittatus (Bloch), Liza parsia (Hamilton) and Oreochromis mossambicus (Peters). J. Microsc. Ultrastruct. 2(4), 245. https://doi.org/10.1016/j.jmau.2014.07.003.

Chang, X., Xue, Y., Li, J., Zou, L., Tang, M., 2020. Potential health impact of environmental micro- and nanoplastics pollution. J. App. Toxicol. 40, 4-15. https://doi.org/10.1002/jat.3915.

Chapman, P.M., 2007. Determining when contamination is pollution - weight of evidence determinations for sediments and effluents. Environ. Int. 33(4), 492-501. https://doi.org/10.1016/j.envint.2006.09.001.

Chapman, P.M., McDonald, B.G., Lawrence, G.S., 2002. Weight-of-Evidence issues and frameworks for sediment quality (And Other) assessments. Hum. Ecol. Risk Asses. 8(7), 1489-1515. https://doi.org/10.1080/20028091057457.

Chau, Y.T., Yap, C.W. 2012. Quantitative nanostructure-activity relationship modelling of nanoparticles. RSC Adv. 2, 8489. https://doi.org/10.1039/C2RA21489J.

Chen, Z., Mayer, L., 1999. Sedimentary metal bioavailability determined by the digestive constraints of marine deposit feeders: Gut retention time and dissolved amino acids. Mar. Ecol. Progr. Ser. 176, 139-151. http://www.jstor.org/stable/24831879.

Chen, Q., Yin, D., Jia, Y., Schiwy, S., Lagradi, J., Yang, S., Hollert, H., 2017. Enhanced uptake of BPA in the presence of nanoplastics can lead to neurotoxic effects in adult zebrafish. Sci. Total Environ. 609, 1312-1321. https://doi.org/10.1016/j.scitotenv.2017.07.144.

Cheshire, A. C., Adler, E., Barbière, J., Cohen, Y., Evans, S., Jarayabhand, S., .... Westphalen, G., 2009. UNEP/IOC Guidelines on survey and monitoring of marine litter. UNEP Regional Seas Reports and Studies, No. 186, IOC Technical Series No. 83: xii + 120 pp. https://doi.org/

Chiba, S., Saitoc, H., Fletcherb, R., Yogid, T., Kayod, M., Miyagid, S., ... Fujikurae, K., 2018. Human footprint in the abyss: 30 year records of deep-sea plastic debris. Mar. Policy 96, 204-212. https://doi.org/10.1016/j.marpol.2018.03.022. 
Choy, C.A., Drazen, J.C., 2013. Plastic for dinner? Observations of frequent debris ingestion by pelagic predatory fishes from the central North Pacific. Mar. Ecol. Prog. Ser. 485, 155-163. https://doi.org/10.3354/meps10342.

Choy, C.A., Robison, B.H., Gagne, T.O., Erwin, B., Firl, E., Halden, R.U., Hamilton, J.A., Katija, K., Lisin, S.E., Rolsky, C., Van Houtan, K.S., 2019. The vertical distribution and biological transport of marine microplastics across the epipelagic and mesopelagic water column. Sci. Rep. 9, 7843. https://doi.org/10.1038/s41598-019-44117-2

Chua, E., Shimeta, J., Nugegoda, D., Morrison, P.D., Clarke, B.O., 2014. Assimilation of Polybrominated Diphenyl Ethers from microplastics by the marine amphipod, Allorchestes compressa. Environ. Sci. Technol. 48(14), 8127-8134. https://doi.org/10.1021/es405717z.

Claessens, M., Monteyne, E., Wille, K., Vanhaecke, L., Roose, P., Janssen, C.R., 2015. Passive sampling reversed: Coupling passive field sampling with passive lab dosing to assess the ecotoxicity of mixtures present in the marine environment. Mar. Pollut. Bull. 93(1), 9-19. https://doi.org/10.1016/j.marpolbul.2015.02.028.

Clark, C.M., Forney, C., Manii, E., Shinzaki, D., Gage, C., Farris, M., Lowe, C.G., Moline, M., 2013. Tracking and following a tagged leopard shark with an autonomous underwater vehicle. J. Field Robotics, 30, 309-322. https://doi.org/10.1002/rob.21450.

Colborn, T., Thayer, K., 2000. Aquatic ecosystems: harbingers of endocrine disruption. Ecol. App. 10(4), 949-957. https://doi.org/10.1890/1051-0761(2000)010[0949:AEHOED]2.0.CO;2.

Cole, M., Lindeque, P., Halsband, C., Galloway, T.S., 2011. Microplastics as contaminants in the marine environment: A review. Mar. Pollut. Bull. 62(12), 2588-2597. https://doi.org/10.1016/j.marpolbul.2011.09.025.

Cole, M., Lindeque, P., Fileman, E., Halsband, C., Goodhead, R., Moger, J., Galloway, T.S., 2013. Microplastic ingestion by zooplankton. Environ. Sci. Technol. 47(12), 6646-6655. https://doi.org/10.1021/es400663f.

Cole, M., Webb, H., Lindeque, P.K., Fileman, E.S., Halsband, C., Galloway, T.S., 2015a. Isolation of microplastics in biota-rich seawater samples and marine organisms. Sci. Rep. 4(1), 4528. https://doi.org/10.1038/srep04528. 
Cole, M., Lindeque, P., Fileman, E., Halsband, C., Galloway, T.S., 2015b. The impact of polystyrene microplastics on feeding, function and fecundity in the marine copepod Calanus helgolandicus. Environ. Sci. Technol. 49(2), 1130-1137. https://doi.org/10.1021/es504525u.

Collignon, A., Hecq, J.-H., Glagani, F., Voisin, P., Collard, F., Goffart, A., 2012. Neustonic microplastic and zooplankton in the North Western Mediterranean Sea. Mar. Poll. Bull. 64(4), 861-864. https://doi.org/10.1016/j.marpolbul.2012.01.011

Colton Jr, J.B., Knapp, F.D., Burns, B.R., 1974. Plastic particles in surface waters of the Northwestern Atlantic. Science, 185(4150), 491-497. https://doi.org/10.1126/science.185.4150.491.

Connor, S.E., Colombaroli, D., Confortini, F., Gobet, E., Ilyashuk, B.P., llyashuk, E.A., van Leeuwen, J.F.N., Lamentowicz, M., van der Knaap, W.O., Malysheva, E., Marchetto, A., Margalitadze, N., Mazei, Y., Mitchell, E.A.D., Payne, R.J., Ammann, B., 2018. Long-term population dynamics: Theory and reality in a peatland ecosystem. J. Ecol. 106(1), 333-346. https://doi.org/10.1111/1365-2745.12865.

Corcoran, P.L., Biesinger, M.C., Grifi, M., 2009. Plastics and beaches: A degrading relationship. Mar. Pollut. Bull. 58(1), 80-84. https://doi.org/10.1016/j.marpolbul.2008.08.022.

Corcoran, P.L., Norris, T., Ceccanese, T., Walzak, M.J., Helm, P.A., Malvin, C.H., 2015. Hidden plastics of Lake Ontario, Canada and their potential preservation in the sediment record. Environ. Pollut. 204, 17-25. https://doi.org/10.1016/j.envpol.2015.04.009.

Cox, K.D., Covernton, G.A., Davies, H.L., Dower, J.F., Juanes, F., Dudas, S.E., 2019. Human consumption of microplastics. Environ. Sci. Technol. 53(12), 7068-7074. https://doi.org/10.1021/acs.est.9b01517.

Cózar, A., Echevarría, F., González-Gordillo, J.I., Irigoien, X., Ubeda, B., Hernandez-Leon, S., Palma, A.T., Navarro, S., Garcia-de-Lomas, J., Ruiz, A., Fernandez-de-Puelles, M.L., Duarte, C.M., 2014. Plastic debris in the open ocean. Proc. Natl. Acad. Sci. USA. 111 (28), 10239-10244. https://doi.org10.1073/pnas.1314705111.

Cózar, A., Sanz-Martín, M., Martí, E., González-Gordillo, J.I., Ubeda, B., Gálvez, J.Á., Irigoien, X., Duarte, C.M., 2015. Plastic accumulation in the Mediterranean Sea. PLoS ONE, 10(4), e0121762. https://doi.org/10.1371/journal.pone.0121762. 
Colabuono, F.I., Barquete, V., Domingues, B.S., Montone, R.C., 2009. Plastic ingestion by Procellariiformes in Southern Brazil. Mar. Pollout. Bull. 58(1), 93-96. https://doi.org/10.1016/j.marpolbul.2008.08.020.

Cwiertny, D.M., Bransfield, S.J., Roberts, A.L., 2007. Influence of the oxidizing species on the reactivity of iron-based bimetallic reductants. Environ. Sci. Technol. 41(10), 3734-3740. https://doi.org/10.1021/es062993s

da Costa, J.P., Santos, P.S.M., Duarte, A.C., Rocha-Santos, T., 2016. (Nano)plastics in the environment - sources, fates and effects. Sci. Total Environ. 566-567, 15-26. https://doi.org/10.1016/j.scitotenv.2016.05.041.

D'Alesaandro, M., Esposite, V., Porporato, E.M.D., Berto, D., Renzi, M., Giacobbe, S., Scotti, G., Consoli, P., Valastro, G., Andaloro, F., Romeo, T., 2018. Relationships between plastic litter and chemical pollutants on benthic biodiversity. Environ. Pollut. 242, 1546-1556. https://doi.org/10.1016/j.envpol.2018.08.002.

Dardel, F., 2016. lon exchange. http://dardel.info/IX/index.html.

Darnerud, P.O., Eriksen, G.S., Jóhannesson, T., Larsen, P.B., Viluksela, M., 2001. Polybrominated diphenyl ethers: Occurrence, dietary exposure, and toxicology. Environ. Health Perspect. 109, 49-68. https://doi.org/10.1289/ehp.01109s149.

Davison, P., Asch, R., 2011. Plastic ingestion by mesopelagic fishes in the North Pacific Subtropical Gyre. Mar. Ecol. Prog. Ser. 432, 173-180. https://doi.org/10.3354/meps09142.

Day, R.H., Wehle, D.H.S., Coleman, F.C., 1985. Ingestion of plastic pollutants by marine birds. Proceedings of the Workshop on the Fate and Impact of Marine Debris. 2, pp. 334-86. US dept. Commerce.

Debrot, A.O., Tiel, A.B., Bradshaw, J.E., 1999. Beach debris in Curacao. Mar. Pollut. Bull. 38, 795-801. https://doi.org/10.1016/S0025-326X(99)00043-0.

Denuncio, P., Bastida, R., Dassis, M., Giardino, G., Gerpe, M., Rodríguez, D., 2011. Plastic ingestion in Franciscana dolphins, Pontoporia blainvillei (Gervais and d'Orbigny, 1844), from Argentina. Mar. Poll. Bull. 62(8), 1836 -1841. https://doi.org/10.1016/j.marpolbul.2011.05.003. 
Desforges, J.P.W., Galbraith, M., Dangerfield, N., Ross, P.S., 2014. Widespread distribution of microplastics in subsurface seawater in the NE Pacific Ocean, Mar. Pollut. Bull. 79(1-2), 94-99. https://doi.org/10.1016/j.marpolbul.2013.12.035.

de Carvalho-Souza, G.F., Llope, M., Tinôco, M.S., Medeiros, D.V., Maia-Nogueira, R., Sampaio, C.L.S., 2018. Marine litter disrupts ecological processes in reef systems. Mar. Pollut. Bull. 133, 464-471. https://doi.org/10.1016/j.marpolbul.2018.05.049.

de Dardel, F., Arden, T.V., 2008. Ion Exchangers. Wiley: Ullmann's Encyclopedia of Industrial Chemistry. https://doi.org/10.1002/14356007.a14_393.pub2.

de Stephanis, R., Giménez, J., Carpinelli, E., Gutierrez-Exposito, C., Cañadas, A., 2013. As main meal for sperm whales: Plastics debris. Mar. Pollut. Bull. 69(1-2), 206-214. https://doi.org/10.1016/j.marpolbul.2013.01.033.

de Souza Machado, A.A., Kloas, W., Zarfl, C., Hempel, S., Rillig, M.C., 2018. Microplastics as an emerging threat to terrestrial ecosystems. Global Chang. Biol. 24(4), 1405-1416. https://doi.org/10.1111/gcb.14020.

Deng, Y., Zhang, Y., Lemos, B., Ren, H., 2017. Tissue accumulation of microplastics in mice and biomarker responses suggest widespread health risks of exposure. Sci. Rep. 7, 46687. https://doi.org/10.1038/srep46687.

de Pierrepont, J.F., Dubois, B., Desormonts, S., Santos, M.B., Robin, J.P., 2005. Stomach contents of English Channel cetaceans stranded on the coast of Normandy. J. Mar. Biol. Assoc. UK. 85, 1539-1546. https://doi.org/10.1017/S0025315405012762.

Desforges, J., Galbraith, M., Dangerfield, N., Ross, P.S., 2014. Widespread distribution of microplastics in subsurface seawater in the NE Pacific Ocean., Mar. Pollut. Bull. 79, 94-99. https://doi.org/10.1016/j.marpolbul.2013.12.035.

Dickhut, R.M., Canuel, E.A., Gustafson, K.E., Liu, K., Arzayus, K.M., Walker, S.E., Edgecombe, G., Gaylor, M.O., MacDonald, E.H., 2000. Automotive sources of carcinogenic polycyclic aromatic hydrocarbons associated with particulate matter in the Chesapeake Bay region. Environ. Sci. Technol. 34(21), 4635-4640. https://doi.org/10.1021/es000971e. 
Di Paolo, C., Seiler, T-B., Keller, S., Hu, M., Brack, W., Hollert, H., 2015. The value of zebrafish as an integrative model in effect-directed analysis-a review. Environ. Sci. Eur. 27, 8. https://doi.org/10.1186/s12302-015-0040-y.

Discharging Microbeads to Our Waters., 2015. New York State Office of the Attorney General: An examination of wastewater treatment plants in New York., 2015. https://ag.ny.gov/pdfs/2015_Microbeads_Report_FINAL.pdf.

Dmitrienko, S.G., Gurariy, E.Ya., Nosov, R.E., Zolotov, Yu. A., 2001. Solid-phase extraction of polycyclic aromatic hydrocarbons from aqueous samples using olyurethane forms in connection with solidmatrix spectrofluroimetry. Anal. Lett. 34 (3), 425-438. https://doi.org/10.1081/AL-100102584.

Doi, Y., Fukuda, K., 1994. Biodegradable plastics and polymers. Amsterdam: Elsevier.

Dong, S., Qu, M., Rui, Q., Wang, D., 2018. Combinational effect of titanium dioxide nanoparticles and nanopolystyrene particles at environmentally relevant concentrations on nematode Caenorhabditis elegans. Ecotoxicol. Environ. Safety, 161, 444-450. https://doi.org/10.1016/j.ecoenv.2018.06.021.

Doyle, M.J., Watson, W., Bowlin, N.M., Sheavly, S.B., 2011. Plastic particles in coastal pelagic ecosystems of the Northeast Pacific ocean. Mar. Environ. Res. 71(1), 41-52. https://doi.org/10.1016/j.marenvres.2010.10.001.

Dris, R., Gasperi, J., Saad, M., Mirande, C., Tassin, B., 2016. Synthetic fibers in atmospheric fallout: A source of microplastics in the environment? Mar. Pollut. Bull. 104(1-2), 290-293. https://doi.org/10.1016/j.marpolbul.2016.01.006.

Du, J., Zhou, Q., Li, H., Xu, H., Wang, C., Fu, L., Tang, J., 2020. Environmental distribution, transport and ecotoxicity of microplastics: a review. J. Appl. Toxicol. 1-13, https://doi.org/10.1002./jat.4034.

Durrieu de Madron, X., Houpert, L., Puig, P., Sanchez-Vidal., A., Testor, P., Bosse, A., Estournel, C., Somot, S., Bourrin, F., Bouin, M.N., Beauverger, M., Beguery, L., Calafat, A., Cnals, M., Cassou, C., Coppola, L., Dausse, D., D’Ortenzio, F., Font, J., Heussner, S. Kunesch, S., Lefevre, D., Le Goff, H., Martin, J., Mortier, L., Palanques, A., Raimbault, P., 2013. Interaction of dense shelf water cascading and open-sea convection in the northwestern Mediterranean during winter 2012. Geophys. Res. Lett. 40, 1379-1385. https://doi.org/10.1002/grl.50331. 
Dubaish, F., Liebezeit, G., 2013. Suspended microplastics and black carbon particles in the jade system, southern north sea. Water Air Soil Pollut. 224 (2), 1352. https://doi.org/10.1007/s11270-0121352-9.

Duperron, S., Halary, S., Gallet, A., Marie, B., 2020. Microbiome-aware ecotoxicology of organisms: relevance, pitfalls, and challenges. Front. Public Health. 8,407. https//doi.org/10.3389/fpubh.2020.00407.

Ecology Center. 1996. Plastic Task Force Report (Berkeley, CA). https://ecologycenter.org/plastics/ptf/.

Endo, S., Takizawa, R., Okuda, K., Takada, H., Chiba, K., Kanehiro, H., Ogi, H., Yamashita, R., Date, T., 2005. Concentration of polychlorinated biphenyls (PCBs) in beached resin pellets: variability among individual particles and regional differences. Mar. Pollut. Bull. 50(10), 1103-1114. https://doi.org/10.1016/j.marpolbul.2005.04.030.

Engler, R.E., 2012. The complex interaction between marine debris and toxic chemicals in the ocean. Environ. Sci. Technol. 46(22), 12302-12315. https://doi.org/10.1021/es3027105.

Eriksson, J., Green, N., Marsh, G., Bergman, Å., 2004. Photochemical decomposition of 15 polybrominated diphenyl ether congeners in methanol/water. Environ. Sci. Technol. 38(11), 3119-3125. https://doi.org/10.1021/es049830t.

Eriksen, M., Mason, S., Wilson, S., Box, C., Zellers, A., Edwards, W., Farley, H., Amato, S., 2013. Microplastic pollution in the surface waters of the Laurentian Great Lakes. Mar. Pollut. Bull. 77(12), 177-182. https://doi.org/10.1016/j.marpolbul.2013.10.007.

Eriksen, M., Maximenko, N., Thiel, M., Cummins, A., Lattin, G., Wilson, S., Hafner, J., Zellers, A., Rifman, S., 2013. Plastic pollution in the South Pacific subtropical gyre. Mar. Pollut. Bull. 68(1-2), 71-76. https://doi.org/10.1016/j.marpolbul.2012.12.021.

Eriksen, M., Lebreton, L.C.M., Carson, H.S., Thiel, M., Moore, C.J., Borerro, J.C., Galgani, F., Ryan, P.G., Reisser, J., 2014. Plastic pollution in the world's oceans: More than 5 trillion plastic pieces weighing over 250,000 tons afloat at sea. PLoS ONE 9 (12), e111913. https://doi.org/10.1371/journal.pone.0111913.

European Commission, 2011. Commission Recommendations of October on the Definition of Nanomaterial (2011/969/EU). 
European Food Safety Authority (EFSA) of Contaminants in the Food Chain., 2011. Scientific opinion on polybrominated diphenyl ethers (PBDEs) in food. EFSA J. 9(5), 2156. https://efsa.onlinelibrary.wiley.com/doi/pdf/10.2903/j.efsa.2011.2156.

European Parliament Council., 2008. Annex VI, Table 3.1 in: Regulation (EC) No 1272/2008 of the European Parliament and of the Council of 16 December 2008 on Classification, Labelling and Packaging of Substances and Mixtures, Amending and Repealing Directives 67/548/EEC and 1999/45/EC, and Amending Regulation (EC) No 1907/2006.

Fabel, S., Niessner, R., Weller, M.G., 2005. Effect-directed analysis by high performance liquid chromatography with gas-segmented enzyme inhibition. J. Chromatogra. A. 1099, 103-110. https://10.1016/j.chroma.2005.08.081.

Fadare, O.O., Okoffo, E.D., 2020. Covid-19 face masks: A potential source of microplastic fibers in the environment. Sci. Total Environ. 737, 140279. https://doi.org/10.1016/j.scitotenv.2020.140279.

Farrell, P., Nelson, K., 2013. Trophic level transfer of microplastic: Mytilus edulis (L.) to Carcinus maenas (L.). Environ. Pollut. 177, 1-3. https://doi.org/10.1016/j.envpol.2013.01.046.

Fendall, L. S., Sewell, M.A., 2009. Contributing to marine pollution by washing your face: microplastics in facial cleansers. Mar. Pollut. Bull. 58, 1225-1228. https:/doi.org/10.1016/j.marpolbul.2009.04.025.

FiberYear., 2017. World survey on textiles \& nonwovens. https://www.thefiberyear.com/fileadmin/pdf/TFY2017_TOC.pdf

Filgueira, R., Rosland, R., Grant, J. 2011. A comparison of scope for growth (SFG) and dynamic energy budget (DEB) models applied to the blue mussel (Mytilus edulis). J. Sea Res. 66(4), 403-410. https://doi.org/10.1016/j.seares.2011.04.006.

Fischer, L., Smith, G., Hann, S., Bruland, K.W., 2018. Ultra-trace analysis of silver and platinum in seawater by ICP-SFMS after off-line matrix separation and pre-concentration. Mar. Chem. 199, 44-52. https://doi.org/10.1016/j.marchem.2018.01.006

Fisner, M., Taniguchi, S., Moreira, F., Bícego, M.C., Turra, A., 2013. Polycyclic aromatic hydrocarbons (PAHs) in plastic pellets: Variability in the concentration and composition at different sediment depths in a sandy beach. Mar. Pollut. Bull. 70(1), 219-226.

https://doi.org/10.1016/j.marpolbul.2013.03.008. 
Foekema, E.M., De Gruijter, C., Mergia, M.T., van Franeker, J.A., Murk, A.J., Koelmans, A.A., 2013. Plastic in North Sea fish. Environ. Sci. Technol. 47(15), 8818-8824. https://doi.org/10.1021/es400931b.

Fok, L., Cheung, P.K., 2015. Hong Kong at the pearl river estuary: A hotspot of microplastic pollution. Mar. Pollut. Bull. 99(1-2), 112-118. https://doi.org/10.1016/j.marpolbul.2015.07.050.

Franzellitti, S., Canesi, L., Auguste, M., Wathsala, R.H.G.R., Fabbri, E. 2019. Microplastic exposure and effects in aquatic organisms: A physiological perspective. Env. Toxicol. Pharmacol. 68, 37-51. https://doi.org/10.1016/j.etap.20.03.009.

Frias, J.P.G.L., Gago, J., Otero, V., Sobral, P., 2016. Microplastics in coastal sediments from Southern Portuguese shelf waters. Mar. Environ. Res. 114, 24-30. https://doi.org/10.1016/j.marenvres.2015.12.006.

Fuchs, A.-K., Syrovets, T., Haas, K.A., Loos, C., Musyanovych, A., Mailänder, V., Landfester, K., Simmet, T., 2016. Carboxyl- and amino-functionalized polystyrene nanoparticles differentially affect the polarization profile of M1 and M2 macrophage subsets. Biomater. 85, 78-87. https://doi.org/10.1016/j.biomaterials.2016.01.064.

Fulton, M., Hong, J., Islam, M.J., Sattar, J., 2018. Robotic detection of marine litter using deep visual detection models. International Conference on Robotics and Automation (ICRA), Montreal, QC, Canada, 2019, pp. 5752-5758. https://doi.org/10.1109/ICRA.2019.8793975.

Galgani, F., Burgeot, T., Bocquene, G., Vincent, F., Leaute, J., Labastie, J., ... Guichet, R., 1995. Distribution and abundance of debris on the continental shelf of the Bay of Biscay and in Seine Bay. Mar. Pollut. Bull. 30, 58-62. https://doi.org/10.1016/0025-326X(94)00101-E

Galgani, F., Souplet, A., Cadiou, Y., 1996. Accumulation of debris on the deep sea floor off the French Mediterranean coast. Mar. Ecol. Prog. Series 142, 225-234.

Galgani, F., Hanke, G., Werner, S., De Vrees, L., 2013. Marine litter within the European Marine Strategy Framework Directive. ICES J. Mar. Sci. 70(6), 1055-1064. https://doi.org/10.1093/icesjms/fst122

Galgani, F., Leaute, J.P., Moguedet, P., Souplet, A., Verin, Y., Carpentier, A., ... Nerisson, P., 2000. Litter on the sea floor along European coasts. Mar. Pollut. Bull. 40, 516-527. https://doi.org/10.1016/S0025-326X(99)00234-9. 
Galgani, F., Piha, H., Hanke, G., Werner, S., Alcaro, L., Mattidi, M., Fleet, D., Kamizoulis, G., Maes, T., Osterbaan, L., Thompson, R., Van Franeker, J., Mouat, J., Meacle, M., Carroll, C., Detloff, K., Kinsey, S., Nilsson, P., Sheavly, S., Svärd, B., Veiga, J., Morison, S., Katsanevakis, S., LopezLopez, L., Palatinus, A., Scoullos, M., De Vrees, L., Abaza, V., Belchior, C., Brooks, C., Budziak, A., Hagebro, C., Holdsworth, N., Rendell, J., Serrano López, A., Sobral, P., Velikova, V., Vlachogianni, T., Wenneker, B., 2011. European Union: Marine Litter: Technical Recommendations for the Implementation of MSFD Requirements: MSFD GES TSG-ML 2011 Report. http://publications.jrc.ec.europa.eu/repository/handle/111111111/22826.

Gall, S.C., Thompson, R.C., 2015. The impact of debris on marine life. Mar. Pollut. Bull. 92(1-2), 170179. https://doi.org/10.1016/j.marpolbul.2014.12.041.

Gallampois, C.M.J., Schymanski, E.L., Krauss, M., Ulrich, N., Bataineh, M., Brack, W. 2015. Multicriteria approach to select polyaromatic river mutagen candidates. Environ. Sci. Technol. 49(5), 29592968. https://doi.org/10.1021/es503640k.

Gallon C., Flegal A.R., 2015. Sources, fluxes, and biogeochemical cycling of silver in the oceans. In: Whitacre D. (eds.) Rev. Envir. Contam. Toxicol. 235, Springer, Cham. https://doi.org/10.1007/978-3-319-10861-2_2.

Galloway T.S, Cole M., Lewis C., 2017. Interactions of microplastic debris throughout the marine ecosystem. Nat. Ecol. Evol. 1 (5), 116. https:/doi.org/10.1038/s41559-017-0116.

Garcia, B., Fang, M.M., Lin, J., 2019. Marine plastic pollution in Asia: All hands on deck! Chinese J. Environ. L. 3, 11-46. https://doi.org/10.1163/24686042-12340034.

Garner, K.L., Keller, A.A. 2014. Emerging patterns for engineered nanomaterials in the environment: a review of fate and toxicity studies. J. Nanopart. Res. 16, 2503. https://doi.org/10.1007/s11051014-2503-2.

Garner, K.L., Suh, S., Lenihan, H.S., Keller, A.A., 2015. Species sensitivity distributions for engineered nanomaterials. Env. Sci. Technol. 49(9), 5753-5759. https://doi.org/10.1021/acs.est.5b00081.

Garnett, E.C., Cai, W., Cha, J.J., Mahmood, F., Connor, S.T., Christoforo, M.G., .. Brongersma, M.L., 2012. Self-limited plasmonic welding of silver nanowire junctions. Nature Mat. 11, 241-249. https://doi.org/10.1038/NMAT3238. 
Gaspar, T.R., Chi, R.J., Parrow, M.W., Ringwood, A.H., 2018. Cellular bioreactivity of micro- and nanoplastic particles in oysters. Front. Mar. Sci. 5, 1-8. https://doi.org/10.3389/fmars.2018.00345.

GESAMP., 2019. Ryan, P., Shim, W., Zhang, W., Mason, S., Galgani, F., Turra, A., Kershaw, P., Hong, S., Hassellöv, M., Lusher, A., Thiel, M., Eriksen, M., Takada, H., Tahir, A., Wilcox, C., Hardesty, B., Uhrin, A. Guidelines for the monitoring \& assessment of plastic litter in the ocean. Reports \& Studies 99 (Kershaw, P.J., Turra, A., Galgani, F., Eds). http://www.gesamp.org/publications/guidelines-for-the-monitoring-and-assessment-of-plasticlitter-in-the-ocean.

Geyer, R., Jambeck, J.R., Law, K.L., 2017. Production, use, and fate of all plastics ever made. Sci. Adv. 3(7), e1700782. https://doi.org/10.1126/sciadv.1700782.

Ghosh, S.K., Pal, S., Ray, S., 2013. Study of microbes having potentiality for biodegradation of plastics. Environ. Sci. Pollut. Res. 20(7), 4339-4355. https://doi.org/10.1007/s11356-013-1706-x.

Ghosh, U., Kane Driscoll, S., Burgess, R.M., Jonker, M.T., Reible, D., Gobas, F., Choi, Y., Apitz, S.E., Maruya, K.A., Gala, W.R., Mortimer, M., Beegan, C., 2014. Passive sampling methods for contaminated sediments: practical guidance for selection, calibration, and implementation. Integr. Environ. Assess. Manag. 10(2):210-223. https://doi.org/10.1002/ieam.1507.

GIA (Global Industry Analysis), 2008. Plastic additives: a global strategic business report (MCP-2122, GIA). https://www.strategyr.com/Plastic_Additives_Market_Report.asp

Goldstein, M. C., Goodwin, D.S., 2013. Gooseneck barnacles (Lepas spp.) ingest microplastic debris in the North Pacific Subtropical Gyre. PeerJ 1, e184. https://doi.org/10.7717/peerj.184

Goldstein, M.C., Rosenberg, M., Cheng, L., 2012. Increased oceanic microplastic debris enhances oviposition in an endemic pelagic insect. Biol. Lett. 8(5), 817-820.

https://doi.org/10.1098/rsbl.2012.0298.

Goldstein, M.C., Timus, A.J., Ford, M., 2013. Scales of spatial heterogeneity of plastic marine debris in the Northeast Pacific Ocean. PLoS ONE, 8(11), e80020. https://doi.org/10.1371/journal.pone.0080020.

Gong, L., 2017. PCB etching technique and analysis of etching solution. Shenzhen See Technology Co., Ltd. https://www.seeedstudio.com/blog/2017/03/16/pcb-etching/ 
González García, M.M., Sánchez Rojas, F., Bosch Ojeda, C., García de Torres, A., Cano Pavón, M., 2003. On-line ion-exchange preconcentration and determination of traces of platinum by electrothermal atomic absorption spectrometry. Anal. Bioanal. Chem. 375, 1229-1233. https://doi.org/10.1007/s00216-002-1679-y

Good, T.P., June, J.A., Etnier, M.A., Broadhurst, G., 2010. Derelict fishing nets in Puget Sound and the Northwest Straits: Patterns and threats to marine fauna. Mar. Pollut. Bull. 60(1), 39-50. https://doi.org/10.1016/j.marpolbul.2009.09.005.

Gore, A.C., 2008. Developmental programming and endocrine disruptor effects on reproductive neuroendocrine systems. Front. Neuroendocrinol. 29, 358-74. https://doi.org/10.1016/j.yfrne.2008.02.002.

Gore, A.C., 2010. Neuroendocrine targets of endocrine disruptors. Horm. Int. J. Endocrinol. Metabol., 9, 16-27. https://doi.org/10.14310/horm.2002.1249

Gouin, T., Roche, N., Lohmann, R., Hodges, G., 2011. A thermodynamic approach for assessing the environmental exposure of chemicals absorbed to microplastic. Envron. Sci. Technol. 45(4), 1466-1472. https://doi.org/10.1021/es1032025.

Groschwitz, K.R., Hogan, S.P., 2009. Intestinal barrier function: Molecular regulation and disease pathogenesis. J. Allergy Clin. Immunol. 124(1), 3-20. https://doi.org/10.1016/j.jaci.2009.05.038.

Gündoğdu, S., Çevik, C., Karaca, S., 2017. Fouling assemblage of benthic plastic debris collected from Mersin Bay, NE Levantine coast of Turkey. Mar. Pollut. Bull. 124(1), 147-154. https://doi.org/10.1016/j.marpolbul.2017.07.023.

Güven, O., Gökdağ, K., Jovanović, B., Kıdeyş, A.E., 2017. Microplastic litter composition of the Turkish territorial waters of the Mediterranean Sea, and its occurrence in the gastrointestinal tract of fish. Environ. Pollut. 223, 286-294. https://doi.org/10.1016/j.envpol.2017.01.025.

Guzzetti, E., Sureda, A., Tejada, S., Faggio, C., 2018. Microplastics in marine organisms: Environmental and toxicological effects. Environ. Toxicol. Pharmacol. 64, 164-171. https://doi.org/10.1016/j.etap.2018.10.009. 
Habib, D., Locke, D.C., Cannone, L.J., 1998. Synthetic fibers as indicators of municipal sewage sludge, sludge products, and sewage treatment plant effluents. Water Air Soil Pollut. 103(1/4), 1-8. https://doi.org/10.1023/A:1004908110793.

Halden, R.U., 2010. Plastics and health risks. Annu. Rev. Public Health. 31(1), 179-194. https://doi.org/10.1146/annurev.publhealth.012809.103714.

Hardy, M.L., 1999. Regulatory status and environmental properties of brominated flame retardants undergoing risk assessment in the EU: DBDPO, OBDPO, PeBDPO and HBCD. Polym. Degrad. Stabil. 64, 545-556. https://doi.org/10.1016/S0141-3910(98)00141-4.

Hardesty, B.D., Harari, J., Isobe, A., Lebreton, L., Maximenko, N., Potemra, J., van Sebille, E., Vethaak, A.D., Wilcox, C., 2017. Using numerical model simulations to improve the understanding of microplastic distribution and pathways in the marine environment. Front. Mar. Sci. 4, 30. https://doi.org/10.3389/fmars.2017.00030.

Harrison, J.P., Hoellein, T.J., Sapp, M., Tagg, A.S., Ju-Nam, Y., Ojeda, J.J., 2018. Microplasticassociated biofilms: A comparison of freshwater and marine environments. In: Wagner, M., Lambert, S. (Eds.), Freshwater Microplastics 58, 181-201. Springer International Publishing. https://doi.org/10.1007/978-3-319-61615-5_9.

Hartmann, N.B., Hüffer, T., Thompson, R.C., Hassellöv, M., Verschoor, A., Daugaard, A.E., Rist, S., Kasson, T., Brennholt, N., Cole, M., Herrling, M.P., Hess, M.C., Ivleva, N.P., Lusher, A.L., Wagner, M., 2019. Are we speaking the same language? Recommendations for a definition and categorization framework for plastic debris. Environ. Sci. Technol. 53(3), 1039-047. https://doi.org/10.1021/acs.est.8b05297.

Harvey, R.G., 1998. Environmental chemistry of PAHs. In A.H. Neilson (Ed.), PAHs and related compounds (pp. 1-54). Berlin, HDB: Springer-Verlag. https://doi.org/10.1007/978-3-540-49697-7.

Healy, M.G., Fenton, O., Forrestal, P.J., Danaher, M., Brennan, R.B., Morrison, L., 2016. Metal concentrations in lime stabilized, thermally dried and anaerobically digested sewage sludges. Waste Management 48, 404-408. https://doi.org/10.1016/j.wasman.2015.11.028.

Helm, P.A., 2017. Improving microplastics source apportionment: a role for microplastic morphology and taxonomy? Royal Soc. Chem. 9, 1328-1331. https://doi.org/10.1039/C7AY90016C. 
Hemjinda, S., Krzan, A., Chiellini, E., Miertus, S., 2005. EDP environmentally degradable polymeric materials and plastics - guidelines to standards and testing practices ICS-UNIDO publication. Int. Ctr. Sci. Technol. Accessed. http://capacitydevelopment.unido.org/wpcontent/uploads/2014/11/41.-Environmentally-Degradable-Polymeric-Materials-and-PlasticsGuidelines.pdf

Hernández, A.B., Brumbaugh, R.D., Frederick, P., Grizzle, R., Luckenbach, M.W., Peterson, C.H., Angelini, C., 2018. Front. Ecol. Environ. 16(8), 463-471. https:/doi.org/10.1002/fee.1935.

Herzke, D., Anker-Nilssen, T., Nøst, T.H., Götsch, A., Christensen-Dalsgaard, S., Langset, M., ... Koelmans, A.A., 2016. Negligible impact of ingested microplastics on tissue concentrations of persistent organic pollutants in northern fulmars off Coastal Norway. Environ. Sci. Technol. 50(4), 1924-1933. https://doi.org/10.1021/acs.est.5b04663.

Heskett, M., Takada, H., Yamashita, R., Yuyama, M., Ito, M., Geok, Y.B., Ogata, Y., Kwan, C., Heckhausen, A., Taylor, H., Powell, T., Morishige, C., Young, D., Patterson, H., Robertson, B., Bailey, E., Mermoz, J., 2012. Measurement of persistent organic pollutants (POPs) in plastic resin pellets from remote islands: Toward establishment of background concentrations for International Pellet Watch. Mar. Pollut. Bull. 64(2), 445-448. https://doi.org/10.1016/j.marpolbul.2011.11.004.

Hesler, M., Aengenheister, L., Ellinger, B., Drexel, R., Straskraba, S., Jost, C., ... Kohl, Y., 2019. Multiendpoint toxicological assessment of polystyrene nano- and microparticles in different biological models in vitro. Toxicol. in Vitro 61, 104610. https://doi.org/10.1016/j.tiv.2019.104610

Hirai, H., Takada, H., Ogata, Y., Yamashita, R., Mizukawa, K., Saha, M., Kwan, C., Moore, C., Gray, H., Laursen, D., Zettler, E. R., Farrington, J. W., Reddy, C. M., Peacock, E. E., Ward, M.W., 2011. Organic micropollutants in marine plastics debris from the open ocean and remote and urban beaches. Mar. Pollut. Bull. 62(8), 1683-1692. https://doi.org/10.1016/j.marpolbul.2011.06.004.

Hoornweg, D., Bhada-Tata, P., 2012. What a waste: A global review of solid waste management. Urban development series; knowledge papers no. 15. World Bank, Washington, DC. World Bank. https://openknowledge.worldbank.org/handle/10986/17388 License: CC BY 3.0 IGO.

Hopewell, J., Dvorak, R., Kosior, E., 2009. Plastics recycling: Challenges and opportunities. Philosop. Trans. R. Soc. B, 364, 2115-2126. https://doi.org/10.1098/rstb.2008.0311 
Horii, Y., Ok, G., Ohura, T., Kannan, K., 2008. Occurrence and profiles of chlorinated and brominated polycyclic aromatic hydrocarbons in waste incinerators. Environ. Sci. Technol. 42(6), 1904-1909. https://doi.org/10.1021/es703001f.

Hu, Y., Gong, M., Wang, J., Bassi, A., 2019. Current research trends on microplastic pollution from wastewater systems: a critical review. Rev. Environ. Sci. Biotechnol. 18, 207-230. https://doi.org/10.1007/s11157-019-09498-w.

Hugo, E.R., Brandebourg, T.D., Woo, J.G., Loftus, J., Alexander, J.W., Ben-Jonathan, N., 2008. Bisphenol A at environmentally relevant doses inhibits adiponectin release from human adipose tissue explants and adipocytes. Environ. Health Perspect. 116(12), 1642-1647. https://doi.org/10.1289/ehp.11537.

Hussain, N., Jaitley, V., Florence, A.T., 2001. Recent advances in the understanding of uptake of microparticulates across the gastrointestinal lymphatics. Adv. Drug Delivery Rev. 50 (1-2), 107142. https://doi.org/10.1016/s0169-409x(01)00152-1

Hutton, I., Carlile, N., Priddel, D., 2008. Plastic ingestion by flesh-footed shearwaters, Puffinus carneipes, and wedge-tailed shearwaters, Puffinus pacificus. Papers and Proceedings of the Royal Society of Tasmania, 142 (1), 67-72. https://doi.org/10.26749/rstpp.142.1.67.

Hwang, J., Choi, D., Han, S., Choi, J., Hong, J., 2019. An assessment of the toxicity of polypropylene microplastics in human derived cells. Sci. Total Environ. 684, 657-669. https://doi.org/10.1016/j.scitotenv.2019.05.071.

Ingkaninan, K., de Best, C.M., van derHeijden, R., Hofte, A.J.P., Karabatak, B., 2000. High-performance liquid chromatography with on-line coupled UV, mass spectrometric and biochemical detection for identification of acetylcholinesterase inhibitors from natural products. J. Chromatogr. A. 872, 6173. https://10.1016/s0021-9673(99)01292-3.

Iñiguez, M.E., Conesa, J.A., Fullana, A., 2017. Microplastics in Spanish table salt. Sci. Rep. 7(1), 8620. https://doi.org/10.1038/s41598-017-09128-x.

Ivanov, V.V., Shapiro, G.I., Huthnance, J.M., Aleynik, D.L., Golovin, P.N., 2004. Cascades of dense water around the world ocean. Prog. Oceanogr. 60, 47-98. https://doi.org/ 10.1016/j.pocean.2003.12.002. 
Jabeen, K., Su, L., Li, J., Yang, D., Tong, C., Mu, J., Shi, H., 2017. Microplastics and mesoplastics in fish from coastal and fresh waters of China. Environ. Pollut. 221, 141-149. https://doi.org/10.1016/j.envpol.2016.11.055.

Jager, T., Ashauer, R., 2018. How to evaluate the quality of toxicokinetic-toxicodynamic models in the context of environmental risk assessment. Integr. Environ. Assess. Manag. 14, 604-614. https://doi.org/10.1002/ieam.2026.

Jâms, I.B., Windsor, F.M., Poudevigne-Durance, T., Ormerod, S.J., Durance, I., 2020. Estimating the size distribution of plastics ingested by animals. Nat. Commun. 11, 1594. https://doi.org/10.1038/s41467-020-15406-6.

Jambeck, J.R., Geyer, R., Wilcox, C., Siegler, T.R., Perryman, M., Andrady, A., Narayan, R., Law, K.L., 2015. Plastic waste inputs from land into the ocean. Sci. 347(6223), 768-771. https://doi.org/10.1126/science.1260352.

Janjaroen, D., Ling, F.Q, Monroy, G., Derlon, N., Morgenroth, E., Boppart, S.A., Liu, W.-T., Nguyen, T.H., 2013. Roles of ionic strength and biofilm roughness on adhesion kinetics of Escherichia coli onto groundwater biofilm grown on PVC surfaces. Water Res. 47(7), 2531-2542. https://doi.org/10.1016/j.watres.2013.02.032.

Janssen, E.M.L., Croteau M.-N., Luoma S. N., Luthy R.G., 2010. Measurement and modeling of polychlorinated biphenylbioaccumulation from sediment for the marine polychaete Neanthes arenaceodentata and response to sorbent amendment. Environ. Sci. Technol. 44, 2857-2863. https://doi.org/10.1021/es901632e

Jeong, C. B., Won, E. J., Kang, H. M., Lee, M. C., Hwang, D. S., Hwang, U. K., Zhou, B., Souissi, S., Lee, S. J., Lee, J. S., 2016. Microplastics size- dependent toxicity, oxidative stress induction, and pJNK and p-p38 activation in the monoghonont rotifer (Brachionus koreanus). Environ. Sci. Technol. 50(16), 8849-8857. https://doi.org/10.1021/acs.est.6b01441.

Jin, Y., Lu, L., Tu, W., Luo, T., Fu, Z., 2019. Impacts of polystyrene microplastic on the gut barrier, microbiota and metabolism of mice. Sci. Total Environ. 649, 308-17. https://doi:10.1016/j.scitotenv.2018.08.353. 
Jonker, M.T.O., Koelmans, A.A., 2001. Polyoxymethylene solid phase extraction as a partitioning method for hydrophobic organic chemicals in sediment and soot. Environ. Sci. Technol. 35 (18), 37423748. https://doi.org/10.1021/es0100470.

Katsanevakis, S., Verriopoulos, G., Nicolaidou, A., Thessalou-Legaki, M., 2007. Effect of marine litter on the benthic megafauna of coastal soft bottoms: A manipulative field experiment. Mar. Pollut. Bull. 54(6), 771-778. https://doi.org/10.1016/j.marpolbul.2006.12.016.

Keller, A.A., Wang, H., Zhou, D., Lenihan, H.S., Cherr, G., Cardinale, B.J., Miller, R., Ji, Z. 2010. Stability and aggregation of metal oxide nanoparticles in natural aqueous matrices. Environ. Sci. Technol. 44, 1962-1967. https://doi.org/10.1021/es902987d.

Kershaw, P., Katsuhiko, S., Lee, S., Leemseth, J., Woodring, D., 2011. United Nations: Emerging issues in our environment: Plastic debris in the ocean. http://wedocs.unep.org/handle/20.500.11822/8276.

Khalaf Allah, H., 2013. Morphological adaptations of digestive tract according to food and feeding habits of the broomtail wrasse, Cheilinus lunulatus. Egypt. J. Aqu. Biol. Fish. 17, 123-141. https://doi.org/10.21608/ejabf.2013.2162

Kirstein, I.V., Kirmizi, S., Wichels, A., Garin-Fernandez, A., Erler, R., Löder, M., Gerdts, G., 2016. Dangerous hitchhikers? Evidence for potentially pathogenic Vibrio spp. on microplastic particles. Mar. Environ. Res. 120, 1-8. https://doi.org/10.1016/j.marenvres.2016.07.004

Kiessling, T., Gutow, L., Thiel, M., 2015. Marine litter as habitat and dispersal vector. In: M. Bergmann, L. Gutow, M. Klages (Eds.), Marine Anthropogenic Litter (pp. 141-181). Springer International Publishing. https://doi.org/10.1007/978-3-319-16510-3_6.

Klemeš, J.J., Fan, Y.V., Tan, R.R., Jiang, P., 2020. Minimising the present and future plastic waste, energy and environmental footprints related to COVID-19. Renew. Sust. Energ. Rev. 127, 109883. https://doi.org/10.1016/j.rser.2020.109883.

Klimisch, H.-J., Andreae, M., Tillmann, U., 1997. A systematic approach for evaluating the quality of experimental toxicological and ecotoxicological data. Reg. Toxicol. Pharmacol. 25(1), 1-5. https://doi.org/10.1006/rtph.1996.1076. 
Koelmans A.A., 2015. Modeling the role of microplastics in bioaccumulation of organic chemicals to marine aquatic organisms. A critical review. In: Bergmann M., Gutow L., Klages M. (eds) Marine Anthropogenic Litter. Springer, Cham. https://doi.org/10.1007/978-3-319-16510-3_11.

Koelmans, A.A., Besseling, E., Wegner, A., Foekema, E.M., 2013. Plastic as a carrier of POPs to aquatic organisms: a model analysis. Environ. Sci. Technol. 47(15), 8992-3. https://doi.org/10.1021/es401169n.

Koelmans, A.A., Bakir, A., Burton, G.A., Janssen, C.R, 2016. Microplastic as a vector for chemicals in the aquatic environment: Critical review and model-supported reinterpretation of empirical studies. Environ. Sci. Technol. 50(7), 3315-3326. https://doi.org/10.1021/acs.est.5b06069.

Koelmans, A.A., Kooi, M., Law, K.L., Sebille, E. van, 2017. All is not lost: Deriving a top-down mass budget of plastic at sea. Environ. Res. Letters, 12(11), 114028. https://doi.org/10.1088/17489326/aa9500.

Kooi, M., van Nes, E.H., Scheffer, M., Koelmans, A.A., 2017. Ups and down in the ocean: effects of biofouling on vertical transport of microplastics. Environ. Sci. Technol. 51(14), 7963-7971. https://doi.org/10.1021/acs.est.6b04702.

Kosuth, M., Mason, S.A., Wattenberg, E.V., 2018. Anthropogenic contamination of tap water, beer, and sea salt. PLoS ONE, 13(4), e0194970. https://doi.org/10.1371/journal.pone.0194970.

Krzan, A., Hemjinda, S., Miertus, S., Corti, A., Chiellini, E., 2006. Standardization and certification in the area of environmentally degradable plastics. Polym. Degrad. Stabil. 91, 2819-2833. https://doi.org/10.1016/j.polymdegradstab.2006.04.034.

Kühn, S., Bravo Rebolledo, E.L., van Franeker, J.A., 2015. Deleterious effects of litter on marine life. In: Bergmann M., Gutow L., Klages, M., (Eds.). Marine Anthropogenic Litter. Springer, Cham. https://doi.org/10.1007/978-3-319-16510-3_4.

Kulkarni, S.A., Feng, S.-S., 2013. Effects of particle size and surface modification on cellular uptake and biodistribution of polymeric nanoparticles for drug delivery. Pharm. Res. 30 (10), 2512-2522. https://doi.org/10.1007/s11095-012-0958-3 
Kubota, M., 1994. A Mechanism for the Accumulation of Floating Marine Debris North of Hawaii. J. Phys. Oceanogr. 24, 1059-1064, https://doi.org/10.1175/15200485(1994)024<1059:AMFTAO>2.0.CO;2.

Lamb, J.B., Willis, B.L., Fiorenza, E.A., Couch, C.S., Howard, R., Rader, D.N., True, J.D., Kelly, L.A., Ahmad, A., Jompa, J., Harvell, C.D., 2018. Plastic waste associated with disease on coral reefs. Sci. 359, 460-462. https://doi.org/10.1126/science.aar3320.

Lambert, S., Sinclair, C., Boxall, A., 2014. Occurrence, degradation, and effect of polymer-based materials in the environment. In: Whitacre, D.M., (Ed.), Reviews of Environmental Contamination and Toxicology, Volume 227 (Vol. 227, pp. 1-53). Springer International Publishing. https://doi.org/10.1007/978-3-319-01327-5_1.

Lang, I.A., 2008. Association of urinary bisphenol A concentration with medical disorders and laboratory abnormalities in adults. JAMA, 300(11), 1303. https://doi.org/10.1001/jama.300.11.1303.

Lassen, C., Løke, S., Hansen L.I., Miljøstyrelsen, D., 1999. Danish EPA: Brominated flame retardants: Substance flow analysis and assessment of alternatives. https://www2.mst.dk/Udgiv/publications/1999/87-7909-416-3/199987-7909-416-3.pdf

Lavender, K., Moret-Ferguson, S.E., Goodwin, D.S., Zettler, E.R., DeForce, E., Kukulka, T., Proskurowski, G., 2014. Distribution of surface plastic debris in the eastern pacific ocean from an 11-year data set. Environ. Sci. Technol. 48, 4732-4738. https://doi.org/10.1021/es4053076.

Law, K.L., 2017. Plastics in the marine environment. Annu. Rev. Mar. Sci. 9(1), 205-229. https://doi.org/10.1146/annurev-marine-010816-060409.

Law, K.L., Starr, N., Siegler, T.R., Jambeck, J.R., Mallos, N.J., Leonard, G.H., 2020. The United States' contribution of plastic waste to land and ocean. Sci. Adv. 6(44), eabd0288. https://doi.org/10.1126/sciadv.abd0288.

Lebreton, L. C.-M., Greer, S.D., Borrero, J.C., 2012. Numerical modelling of floating debris in the world's oceans. Mar. Pollut. Bull. 64(3), 653-661. https://doi.org/10.1016/j.marpolbul.2011.10.027.

Lebreton, L.C.M., van der Zwet, J., Damsteeg, J., Slat, B., Andrady, A., Reisser, J., 2017. River plastic emissions to the world's oceans. Nat. Commun. 8, 156. https://doi.org/10.1038/ncomms15611. 
Lebreton, L., Slat, B., Ferrari, F., Sainte-Rose, B., Aitken, J., Marthouse, R., Hajbane, S., Cunsolo, S., Schwarz, S., Levivier, A., Noble, K., Debeljak, P., Maral., H., Schoeneich-Argent, R., Brambini, R., Reisser, J., 2018. Evidence that the Great Pacific Garbage Patch is rapidly accumulating plastic. Sci. Rep. 8, 4666. https://doi.org/10.1038/s41598-018-22939-w.

Lebreton, L., Egger, M., Slat, B., 2019. A global mass budget for positively buoyant macroplastic debris in the ocean. Sci. Rep. 9(1), 12922. https://doi.org/10.1038/s41598-019-49413-5.

Lechner, A., Ramler, D., 2015. The discharge of certain amounts of industrial microplastic from a production plant into the river Danube is permitted by the Austrian legislation. Environ. Pollut. 200, 159-160. https://doi.org/10.1016/j.envpol.2015.02.019.

Lee, J., Hong, S., Song, Y.K., Hong, S.H., Jang, Y.C., Jang, M., Heo, N.W., Han, G.M., Lee, M. J., Kang, D., Shim, W.J., 2013. Relationships among the abundances of plastic debris in different size classes on beaches in South Korea. Mar. Pollut. Bull. 77(1-2), 349-354. https://doi.org/10.1016/j.marpolbul.2013.08.013.

Legradi, J.B., Di Paolo, C., Kraak, M.H.S., van der Geest, H.G., Schymanski, E.L., Williams, A.J., Dingemans, M.M.L., Massei, R., Brack, W., Cousin, X., Begout, M.-L., van der Oost, R., Carion, A., Suarez-Ulloa, V., Silvestre, F., Escher, B.I., Engwall, M., Nilén, G., Keiter, S.H., Pollet, D., Waldmann, P., Kienle, C., Werner, I., Haigis, A.-C., Knapen, D., Vergauwen, L., Spehr, M., Schulz, W., Busch, W., Leuthold, D., Scholz, S., vom Berg, C.M., Basu, N., Murphy, C.A., Lampert, A., Kuckelkorn, J., Grummt, T., Hollert, H. 2018. An ecotoxicological view on neurotoxicity assessment. Environ. Sci. Eur. 30, 46. https://doi.org/10.1186/s12302-018-0173-x.

Lehner, R., Weder, C., Petri-Fink, A., Rothen-Rutishauser, B., 2019. Emergence of nanoplastic in the environment and possible impact on human health. Environ. Sci. Techno. 53(4), 1748-1765. https://doi.org/10.1021/acs.est.8b05512.

Lenz, R., Enders, K., Stedmon, C.A., Mackenzie, D.M.A., Nielsen, T.G., 2015. A critical assessment of visual identification of marine microplastic using Raman spectroscopy for analysis improvement. Mar. Pollut. Bull. 10(1), 82-91. http://doi.org/10.1016/j.marpolbul.2015.09.026. 
Li, X., Huang, J., Fang, L., Yu, G., Lin, H., Wang, L., 2008. Photodegradation of 2,2',4,4'tetrabromodiphenyl ether in nonionic surfactant solutions. Chemosphere, 73(10), 1594-1601. https://doi.org/10.1016/j.chemosphere.2008.08.031

Liao, C., Liang, X., Soupir, M.L. Jarboe, L.R., 2015. Cellular, particle and environmental parameters influencing attachment in surface waters: a review. J. Appl. Microbiol. 119(2), 315-330. https://doi.org/10.1111/jam.12860.

Liebezeit, G., Dubaish, F., 2012. Microplastics in beaches of the east frisian islands spiekeroog and kachelotplate. Bull. Environ. Cont. Toxicol. 89(1), 213-217. https://doi.org/10.1007/s00128-0120642-7.

Liebmann B., Köppel S., Königshofer P., Bucsics T., Reiberger T., Schwabl P., 2018. Assessment of microplactic concentrations in human stool - final results of a prospective study. Int. J. Emerg. Contam. https://doi.org/10.13140/RG.2.2.16638.02884.

Lim, S.L., Ng, C.T., Zou, L., Lu, Y., Chen, J., Bay, B.H., Shen, H.-M., Ong, C.N., 2019. Targeted metabolomics reveals differential biological effects of nanoplastics and nanoZnO in human lung cells. Nanotoxicology 13(8), 1117-1132. https://doi.org/10.1080/17435390.2019.1640913.

Lima, A.R., Costa, M.F., Barletta, M., 2014. Distribution patterns of microplastics within the plankton of a tropical estuary. Environ. Res. 132, 146-155. https://doi:10.1016/j.envres.2014.03.031.

Lima, I.D., Lam, P.J., Doney, S.C., 2014. Dynamics of particulate organic carbon flux in a global ocean model. Biogeosciences 11(4), 1177-1198. https://doi.org/10.5194/bg-11-1177-2014.

Lithner, D., Damberg, J., Dave, G., Larsson, K., 2009. Leachates from plastic consumer productsscreening for toxicity with Daphnia magna. Chemosphere, 74(9), 1195-1200. https:/doi.org/10.1016/j.chemosphere.2008.11.022.

Lithner, D., Larsson, A., Dave, G., 2011. Environmental and health hazard ranking and assessment of plastic polymers based on chemical composition. Sci. Total Environ. 409(18), 3309-3324. https://doi.org/10.1016/j.scitotenv.2011.04.038.

Liu, L., Li, H., Wang, Z., Liu, R., Zhang, Y., Lin, K., 2015. Insights into spatially and temporally cooccurring polybrominated diphenyl ethers in sediments of the East China Sea. Chemosphere, 123, 55-63. https://doi.org/10.1016/j.chemosphere.2014.12.022. 
Liu, Y., Li, W., Lao, F., Liu, Y., Wang, L., Bai, R., Zhao, Y., Chen, C., 2011. Intracellular dynamics of cationic and anionic polystyrene nanoparticles without direct interaction with mitotic spindle and chromosomes. Biomater. 32(32), 8291-8303. https://doi.org/10.1016/j.biomaterials.2011.07.037.

Liu, Z., Yu, P., Cai, M., Wu, D., Zhang, M., Chen, M., Zhao, Y., 2019. Effects of microplastics on the innate immunity and intestinal microflora of juvenile Eriocheir sinensis. Sci. Total Environ. 685, 836-846. https://doi.org/10.1016/j.scitotenv.2019.06.265.

Liu, Z., Li, Y., Pérez, E., Jiang, Q., Chen, Q., Jiao, Y., Huang, Y., Yang, Y., Zhao, Y., 2021. Polystyrene nanoplastic induces oxidative stress, immune defense, and glycometabolism change in Daphnia pulex: Application of transcriptome profiling in risk assessment of nanoplastics. J. Hazard. Mat. 402, 123778. https://doi.org/10.1016/j.jhazmat.2020.123778.

Loakeimidis, C., Papatheodorou, G., Fermeli, G., Streftaris, N., Papathanassiou, E., 2015. Use of ROV for assessing marine litter on the sea floor of Saronikos Gulf (Greece): a way to fill data gaps and deliver environmental education. Springer Plus. 4(463). https://doi.org/10.1186/s40064-015-12484.

Lobelle, D., Cunliffe, M., 2011. Early microbial biofilm formation on marine plastic debris. Mar. Pollut. Bull. 62(1), 197-200. https://doi.org/10.1016/j.marpolbul.2010.10.013.

Lohmann, R., 2015. Correction to critical review of low-density polyethylene's partitioning and diffusion coefficients for trace organic contaminants and implications for its use as a passive sampler. Environ. Sci. Technol. 49(6), 3985. https://doi.org/10.1021/acs.est.5b01017.

Long, M., Moriceau, B., Gallinari, M., Lambert, C., Huvet, A., Raffray, J., Soudant, P., 2015. Interactions between microplastics and phytoplankton aggregates: Impact on their respective fates. Mar. Chem. 175, 39-46. https://doi.org/10.1016/j.marchem.2015.04.003.

Lu, Y., Zhang, Y., Deng, Y., Jiang, W., Zhao, Y., Geng, J., ... Ren, H., 2016. Uptake and accumulation of polystyrene microplastics in zebrafish (Danio rerio) and toxic effects in liver. Environ. Sci. Technol. 50(7), 4054-4060. https://doi.org/10.1021/acs.est.6b00183.

Lu, L., Wan, Z., Luo, T., Fu, Z., Jin, Y., 2018. Polystyrene microplastics induce gut microbiota dysbiosis and hepatic lipid metabolism disorder in mice. Sci. Total Environ. 631-632, 449-458. https://doi.org/10.1016/j.scitotenv.2018.03.051. 
Lusher, A.L., McHugh, M., Thompson, R.C., 2013. Occurrence of microplastics in the gastrointestinal tract of pelagic and demersal fish from the English Channel. Mar. Pollut. Bull. 67(1-2), 94-99. https://doi.org/10.1016/j.marpolbul.2012.11.028.

Lusher, A.L., A. Burke, I. O'Connor, R. Officer., 2014. Microplastic pollution in the Northeast Atlantic Ocean: validated and opportunistic sampling. Mar. Pollut. Bull. 88(1-2), 325-333. https://doi.org/10.1016/j.marpolbul.2014.08.023.

Lusher, A.L., Welden, N.A., Sobral, P., Cole, M., 2017. Sampling, isolating and identifying microplastics ingested by fish and invertebrates. Anal. Methods, 9(9), 1346-1360. https://doi.org/10.1039/C6AY02415G.

Lynch, I., Weiss, C., Valsami-Jones, E. 2014. A strategy for grouping of nanomaterials based on key physico-chemical descriptors as a basis for safer-by-design NMs. Nano Today. 9(3), 266-270. https://doi.org/10.1016/j.nantod.2014.05.001.

Ma, J., Horii, Y., Cheng, J., Wang, W., Wu, Q., Ohura, T., Kannan, K., 2009. Chlorinated and parent polycyclic aromatic hydrocarbons in environmental samples from an electronic waste recycling facility and a chemical industrial complex in China. Environ. Sci. Technol. 43(3), 643-649. https://doi.org/10.1021/es802878w.

Mahon, A.M., O'Connell, B., Healy, M.G., O'Connor, I., Officer, R., Nash, R., Morrison, L., 2017. Microplastics in sewage sludge: Effects of treatment. Environ. Sci. Technol. 51(2), 810-818. https://doi.org/10.1021/acs.est.6b04048.

Mai, L., Sun, X.F., Xia, L.L., Bao, L.J., Liu, L.Y., Zeng, E.Y., 2020. Global riverine plastic outflows. Environ. Sci. Technol. 54, 10049-10056. https://doi.org/10.1021/acs.est.0c02273.

Martinez, E., Maamaatuaiahutapu, K., Taillandier, V., 2009. Floating marine debris surface drift: Convergence and accumulation toward the South Pacific subtropical gyre. Mar. Pollut. Bull. 58, 1347-1355.https://doi.org/10.1016/j.marpolbul.2009.04.022.

Mason, S.A., Garneau, D., Sutton, R., Chu, Y., Ehmann, K., Barnes, J., Fink, P., Papazissimos, D., Rogers, D.L., 2016. Microplastic pollution is widely detected in US municipal wastewater treatment plant effluent. Environ. Pollut. 218, 1045-1054. https://doi.org/10.1016/j.envpol.2016.08.056. 
Mathalon, A., Hill, P., 2014. Microplastic fibers in the intertidal ecosystem surrounding Halifax Harbor, Nova Scotia. Mar. Pollut. Bull. 81(1), 69-79. https://doi.org/10.1016/j.marpolbul.2014.02.018.

Mato, Y., Isobe, T., Takada, H., Kanehiro, H., Otake, C., Kaminuma, T., 2001. Plastic resin pellets as a transport medium for toxic chemicals in the marine environment. Environ. Sci. Technol. 35, 318324. https://doi.org/10.1021/es0010498.

McCauley, S.J., Bjorndal, K.A., 1999. Conservation implications of dietary dilution from debris ingestion: Sublethal effects in post-hatchling loggerhead sea turtles. Conserv. Biol. 13, 925-929. https://doi.org/10.1046/j.1523-1739.1999.98264.x.

McCormick, A., Hoellein, T.J., Mason, S.A., Schluep, J., Kelly, J.J., 2014. Microplastic is an abundant and distinct microbial habitat in an urban river. Environ. Sci. Technol. 48(20), 11863-11871. https://doi.org/10.1021/es503610r

Mizukawa, K., Takada, H., Ito, M., Geok, Y.B., Hosoda, J., Yamashita, R., Saha, M., Suzuki, S., Miguez, C., Frias, J., Antunes, J.C., Sobral, P., Santos, I., Micaelo, C., Ferreira, A.M., 2013. Monitoring of a wide range of organic micropollutants on the Portuguese coast using plastic resin pellets. Mar. Pollut. Bull. 70(1-2), 296-302. https://doi.org/10.1016/j.marpolbul.2013.02.008.

M'koma, A.E., 2013. Inflammatory bowel disease: An expanding global health problem. Clin. Med. Insights: Gastroenterology, 6, 33-47. https://doi.org/10.4137/CGast.S12731.

Moermond, C.T.A., Kase, R., Korkaric, M., Ågerstrand, M., 2016. CRED: Criteria for reporting and evaluating ecotoxicity data. Environmental Toxicology and Chemistry, 35(5), 1297-1309. https://doi.org/10.1002/etc.3259.

Mordecai, R., Mattsson, B., Tzilkowski, C.J., Cooper, R., 2011. Addressing challenges when studying mobile or episodic species: Hierarchical Bayes estimation of occupancy and use. J. App. Ecol., 48, 56-66. https://doi.org/10.1111/j.1365-2664.2010.01921.x.

Moore, C.J., Moore, S.L., Leecaster, M.K., Weisberg, S.B., 2001. A comparison of plastic and plankton in the North Pacific Central Gyre. Mar. Pollut. Bull. 42(12), 1297-1300. https://doi.org/10.1016/S0025-326X(01)00114-X.

Moore, C.J., Lattin, G.L., Zellers, A.F., 2005. A brief analysis of organic pollutants sorbed to pre and postproduction plastic particles from the Los Angeles and San Gabriel River Watersheds. In: 
Proceedings of the Plastic Debris Rivers to Sea Conference, Algalita Marine Research Foundation, Long Beach, CA.

Moore, C.J., Moore, S.L., Weisberg, S.B., Lattin, G.L., Zellers, A.F., 2002. A comparison of neustonic plastic and zooplankton abundance in southern California's coastal waters. Mar. Pollut. Bull. 44(10), 1035-1038. https://doi.org/10.1016/S0025-326X(02)00150-9.

Moore, C.J. 2008. Synthetic polymers in the marine environment: A rapidly increasing, long-term threat. Environ. Res. 108 (2), 131-139. https://doi.org/10.1016/j.envres.2008.07.025.

Moser, M., D. Lee., 1992. A Fourteen-Year Survey of Plastic Ingestion by Western North Atlantic Seabirds. Colonial Waterbirds, 15(1), pp. 83-94. https://doi.org/10.2307/1521357.

Mrosovsky, N., Ryan, G.D., James, M.C., 2009. Leatherback turtles: The menace of plastic. Mar. Pollut. Bull. 58 (2), 287-289. https://doi.org/10.1016/j.marpolbul.2008.10.018.

Munno, E.K., 2017. Microplastic retention by type in several species of fish from the Great Lakes. M.Sc. thesis. Univ. of Toronto. https://tspace.library.utoronto.ca/handle/1807/77870.

Mutha, N., Patel, M., Premnath, V., 2006. Plastics materials flow analysis for India. API Resour. Conserv. Recycl. 47, 222-244. https://doi.org/10.1016/j.resconrec.2005.09.003.

Murphy, C.L., 2018. A comparison of microplastics in farmed and wild shellfish near Vancouver Island and potential implications for contaminant transfer to humans. https://doi.org/10.25316/IR-484.

Murray, F., Cowie, P.R. 2011. Plastic contamination in the decapod crustacean Nephrops norvegicus (Linnaeus, 1758). Mar. Pollut. Bull. 62(6), 1207-1217. https://doi.org/10.1016/j.marpolbul.2011.03.032.

Murray, J.S., Paulsen, K., Politzer, P., 1994. Molecular surface electrostatic potentials in the analysis of non-hydrogen-bonding noncovalent interactions. Proc. Indian Acad. Sci. (Chemical Sciences) 106, 267-275. https://doi.org/10.1007/BF02840749.

Murray, F., Cowie, P.R. 2011. Plastic contamination in the decapod crustacean Nephrops norvegicus (Linnaeus, 1758). Mar. Pollut. Bull. 62(6), 1207-1217. https://doi.org/10.1016/j.marpolbul.2011.03.032. 
National Toxicology Program \#309 (NTP \#309, US)., 1986. National Institutes of Health: Toxicology and carcinogenesis studies of decabromodiphenyl oxide in $\mathrm{F}_{344 / \mathrm{N}}$ rats and $\mathrm{B} \mathrm{C}_{3} \mathrm{~F}_{1}$ mice. https://ntp.niehs.nih.gov/ntp/htdocs/lt_rpts/tr309.pdf.

Navarro, E., Baun, A., Behra, R., Hartmann, N.B., Filser, J., Miao, A-J.,Quigg, A., Santschi, P.H. Sigg, L., 2008. Environmental behavior and ecotoxicity of engineered nanoparticles to algae, plants, and fungi. Ecotoxicol. 17, 372-386. https://doi.org/10.1007/s10646-008-0214-0.

NRC, 2012. A Research Strategy for Environmental, Health, and Safety Aspects of Engineered Nanomaterials. Washington, DC: The National Academies Press. https://doi.org/10.17226/13347. NTP, 1975. Principles for Evaluating Chemicals in the Environment. A Report of the Committee for the Working Conference on Principles of Protocols for Evaluating Chemicals in the Environment. National Academy of Sciences, Washington, D.C., USA. https://www.ncbi.nlm.nih.gov/books/NBK224131/\#top

NTP, 1986. National Institutes of Health: Toxicology and carcinogenesis studies of decabromodiphenyl oxide in $\mathrm{F} 344 / \mathrm{N}$ rats and $\mathrm{B}_{6 \mathrm{C} 3 \mathrm{~F}_{1}}$ mice. Washington, D.C., USA.

https://ntp.niehs.nih.gov/ntp/htdocs/lt_rpts/tr309.pdf

Nadal, M.A., Alomar, C., Deudero, S., 2016. High levels of microplastic ingestion by the semipelagic fish bogue Boops boops (L.) around the Balearic Islands. Environ. Pollut. 214, 517-523. https://doi.org/10.1016/j.envpol.2016.04.054.

Nielsen, T.D., Hasselbalch, J., Holmberg, K., Stripple, J., 2020. Politics and the plastic crisis: A review throughout the plastic life cycle. WIREs Energy Environ. 9(1): e360. https://doi.org/10.1002/wene.360.

Norris, J.M., Ehramantraut, J.W., Gibbons, C.L., Kociba, R.J., Schwetz, B.A., Rose, J Q., Humiston, C.G., Jewett, G.L., Grammett, W.B., Gehring, P.J., Tirsell, J.B., Brosier, J.S., 1973. Toxicological and environmental factors involved in the selection of decabromodiphenyl oxide as a fire retardant chemical. App. Polym. Symposium, 22, 195-219. https://hero.epa.gov/hero/index.cfm/reference/details/reference_id/1716667. 
Obbard, R.W., Sadri, S., Wong, Y.Q., Khitun, A.A., Baker, I., Thompson, R.C., 2014. Global warming releases microplastic legacy frozen in Arctic Sea ice. Earth's Future, 2(6), 315-320. https://doi.org/10.1002/2014EF000240.

Oehlmann, J., Schulte-Oehlmann, U., Kloas, W., Jagnytsch, O., Lutz, I., Kusk, K.O., Wollenberger, L., Santos, E.M., Paull, G.C., Van Look, K.J.W., Tyler, C.R., 2009. A critical analysis of the biological impacts of plasticizers on wildlife. Philos. T. Roy. Soc. B. 364(1526), 2047-2062. https://doi.org/10.1098/rstb.2008.0242.

Ogata, Y., Takada, H., Mizukawa, K., Hirai, H., Iwasa, S., Endo, S., Mato, Y., Saha, M., Okuda, K., Nakashima, A., Murakami, M., Zurcher, N., Booyatumanondo, R., Zakaria, M.P., Dung, L.Q., Gordon, M., Miguez, C., Suzuki, S., Moore, C., Karapanagioti, H.K., Weerts, S., McClurg, T., Burres, E., Smith, W., Van Velkenburg, M., Lang, J.S., Lang, R.C., Laursen, D., Danner, B., Stewardson, N., Thompson, R.C., 2009. International Pellet Watch: Global monitoring of persistent organic pollutants (POPs) in coastal waters. 1. Initial phase data on PCBs, DDTs, and HCHs. Mar. Pollut. Bull. 58(10), 1437-1446. https://doi.org/10.1016/j.marpolbul.2009.06.014. Oliveira, M., Ribeiro, A., Hylland, K., Guilhermino, L., 2013. Single and combined effects of microplastics and pyrene on juveniles $(0+$ group) of the common goby Pomatoschistus microps (Teleostei, Gobiidae). Ecol. Indic. 34, 641-647. https://doi.org/10.1016/j.ecolind.2013.06.019.

Orellana-Paucar, A.M., Serruys, A-S.K., Afrikanova, T., Maes, J., De Borggraeve, W., Alen, J., LeónTamariz, F., Wilches-Arizábala, I.M., Crawford, A.D., de Witte, P.A.M.,Esguerra, C.V. 2012. Anticonvulsant activity of bisabolene sesquit-erpenoids of Curcuma longa in zebrafish and mouse seizure models. Epilepsy Behav. 24, 14-22. https://10.1016/j.yebeh.2012.02.020.

Paget, V., Dekali, S., Kortulewski, T., Grall, R., Gamez, C., Blazy, K., Aguerre-Chariol, O., Chevillard, S., Braun, A., Rat, P., Lacroix, G., 2015. Specific pptake and genotoxicity induced by polystyrene nanobeads with distinct surface chemistry on human lung epithelial cells and macrophages. PLoS ONE, 10(4), e0123297. https://doi.org/10.1371/journal.pone.0123297.

Patel, M.M., Goyal, B.R., Bhadada, S.V., Bhatt, J.S., Amin, A.F., 2009. Getting into the brain: Approaches to enhance brain drug delivery. CNS Drugs, 23(1), 35-58. https://doi.org/10.2165/0023210200923010-00003 
Paul-Pont, I., Tallec, K., Gonzalez-Fernandez, C., Lambert, C., Vincent, D., Mazurais, D., ZamboninoInfante, J.-L., Brotons, G., Lagarde, F., Fabioux, C., Soudant, P., Huvet, A., 2018. Constraints and priorities for conducting experimental exposures of marine organisms to microplastics. Front. Mar. Sci. 5, 252. https://doi.org/10.3389/fmars.2018.00252.

Peters, C.A., Thomas, P.A., Rieper, K.B., Bratton, S.P., 2017. Foraging preferences influence microplastic ingestion by six marine fish species from the Texas Gulf Coast. Mar. Pollut. Bull. 124(1), 82-88. https://doi.org/10.1016/j.marpolbul.2017.06.080.

Pettigrew A., 1993. Halogenated flame retardants. In: Kroschwitz, J., Howe-Grant, M., (Eds.). Kirk-Othmer Encyclopedia of Chemical Technology. 4th ed. Vol. 10. New York, NY: John Wiley and Sons. pp. 954-976.

Petosa, A.R., Jaisi, D.P., Quevedo, I.R., Elimelech, M., Tufenkji, N. 2010. Aggregation and deposition of engineered nanomaterials in aquatic environments: role physico-chemical interactions. Environ. Sci. Technol. 44, 6532-6549. https://doi.org/10.1021/es100598h.

Pettit, T.N., Grant, G.S., Whittow, G.C., 1981. Ingestion of plastics by Laysan albatross. Auk. 98, 839 841. https://doi.org/10.1093/auk/98.4.839a.

Phillips, M.B., Bonner, T.H., 2015. Occurrence and amount of microplastic ingested by fishes in watersheds of the Gulf of Mexico. Mar. Pollut. Bull. 100 (1), 264-269. https://doi.org/10.1016/j.marpolbul.2015.08.041.

Pitt, J.A., Kozal, J.S., Jayasundara, N., Massarsky, A., Trevisan, R., Geitner, N., Wiesner, M., Levin, E.D., Di Giulio, R.T., 2018. Uptake, tissue distribution, and toxicity of polystyrene nanoparticles in developing zebrafish (Danio rerio). Aquat. Toxicol. 194, 185-194. https://doi.org/10.1016/j.aquatox.2017.11.017.

Piva, F., Ciaprini, F., Onorati, F., Benedetti, M., Fattorini, D., Ausili, A., 2011. Assessing sediment hazard through a weight of evidence approach with bioindicator organisms: apractical model to elaborate data from sediment chemistry, bioavailability, biomarkers and ecotoxicological bioassays. Chemosphere, 83, 475-85.

PlasticsEurope, 2006. Association of Plastics Manufacturers: The compelling facts about plastics: An analysis of plastics production, demand and recovery for 2006 in Europe. 
https://www.plasticseurope.org/application/files/2815/1689/9283/2006compelling_fact_PubJan20 08.pdf

PlasticsEurope, 2012. Association of Plastics Manufacturers: Plastics - the Facts 2012: An analysis of European plastics production, demand and waste data for 2011. https://www.plasticseurope.org/en/resources/publications/109-plastics-facts-2012.

PlasticsEurope, 2013. Association of Plastics Manufacturers: Plastics - the Facts 2013: An analysis of European latest plastics production, demand and waste data. https://www.plasticseurope.org/application/files/7815/1689/9295/2013plastics_the_facts_PubOct2 013.pdf

PlasticsEurope, 2016. Association of Plastics Manufacturers: Plastics t the Facts 2016: An analysis of European plastics production, demand and waste data. https://www.plasticseurope.org/application/files/4315/1310/4805/plastic-the-fact-2016.pdf.

Plotkin, P., Amos, A., 1990. NOAA Technical Memorandum NMFS-SEFC-154, Honolulu, Hawaii: Proceedings of the Second International Conference on Marine Debris: Effects of anthropogenic debris on sea turtles in the Northwestern Gulf of Mexico. pp. 736-743. https://pdfs.semanticscholar.org/64c5/10b1ea81e4f889784c7bd02011d817b24baa.pdf.

Poma, A., Vecchiotti, G., Colafarina, S., Zarivi, O., Aloisi, M., Arrizza, L., Chichiriccò, G., Di Carlo, P., 2019. In vitro genotoxicity of polystyrene nanoparticles on the human fibroblast Hs27 cell line. Nanomaterials 9(9), 1299. https://doi.org/10.3390/nano9091299.

Powell, J.J., Faria, N., Thomas-McKay, E., Pele, L.C., 2010. Origin and fate of dietary nanoparticles and microparticles in the gastrointestinal tract. J. Autoimmun. 34(3). https://doi.org/10.1016/j.jaut.2009.11.006.

Ponsonnet, L., Boureanu, M., Jaffrezic, N., Othmane, A., Dorel, C., Lejeune, P., 2008. Local pH variation as an initial step in bacterial surface-sensing and biofilm formation. Mat. Sci. Eng. C, $28 C(5)$, 896-900. https://doi.org/10.1016/j.msec.2007.10.031.

Posthuma, L., Brown, C.D., de Zwart, D., Diamond, J., Dyer, S.D., Holmes, C.M., Marshall, S., Burton Jr., G.A., 2018. Prospective mixture risk assessment and management prioritizations for river 
catchments with diverse land uses. Environ. Toxicol. Chem. 37(3), 715-728. https://doi.org/10.1002/etc.3960.

Pruter, A.T., 1987. Sources, quantities and distribution of persistent plastics in the marine environment. Mar. Pollut. Bull. 18(6), 305-310. https://doi.org/10.1016/S0025-326X(87)80016-4.

Qiao, R., Deng, Y., Zhang, S., Wolosker, M. B., Zhu, Q., Ren, H., Zhang, Y., 2019. Accumulation of different shapes of microplastics initiates intestinal injury and gut microbiota dysbiosis in the gut of zebrafish. Chemosphere, 236, 124334. https://doi.org/10.1016/j.chemosphere.2019.07.065.

Quu, Q., Peng, J., Yu, X., Chen, F., Wang, J., Dong, F., 2015. Occurrence of microplastics in the coastal marine environment: First observation on sediment of China. Mar Pollut. Bull. 98(1-2), 274-280. https://doi.org/10.1016/j.marpolbul.2015.07.028.

Qu, G., Shi, J., Wang, T., Fu, J., Li, Z., Wang, P. 2011. Identification of tetrabromobisphenol A diallyl ether as emerging neurotoxicant in environmental samples by bioassay-directed fractionation and HPLC-APCI-MS/MS. Environ. Sci. Technol. 45, 5009-5016. https://doi.org/10.1021/es2005336.

Qu, M., Nida, A., Kong, Y., Du, H., Xiao, G., Wang, D., 2019. Nanopolystyrene at predicted environmental concentration enhances microcystin-LR toxicity by inducing intestinal damage in Caenorhabditis elegans. Ecotoxicol. Environ. Safety, 183, 109568. https://doi.org/10.1016/j.ecoenv.2019.109568.

Rahman, M.S., Thomas, P., 2018. Interactive effects of hypoxia and PCB co-exposure on expression of CYP1A and its potential regulators in Atlantic croaker liver. Environ. Toxicol. 33, 411-421. https://doi.org/10.1002/tox.22527.

Rahman, M.S., Thomas, P., 2019. Molecular cloning and characterization of two ARNT (ARNT-1 and ARNT-2) genes in Atlantic croaker and their expression during coexposure to hypoxia and PCB77. Environ. Toxicol. 34, 160-171. https://doi.org/10.1002/tox.22670.

Rahman, S., Khan, I.A., Thomas, P., 2011. Tryptophan hydroxylase: a target for neuroendocrine disruption. J. Toxicol. Environ. Health B Crit. Rev. 14(5-7), 473-494. https://doi.org/10.1080/10937404.2011.578563.

Rahman, M.S., Kline, R.J., Vázquez, O.A., Khan, I.A., Thomas, P., 2020. Molecular characterization and expression of arginine vasotocin V1a2 receptor in Atlantic croaker brain: Potential mechanisms of 
its downregulation by PCB77. J. Biochem. Mol. Toxicol. 34, e22500.

https://doi.org/10.1002/jbt.22500.

Rajaram, S., 2009. Plastic additives: the global market (PLS022B, BCC Research).

https://www.bccresearch.com/market-research/plastics/plastic-additives-market-pls022b.html.

Raju, S., Carbery, M., Kuttykattil, A., Senathirajah, K., Subashchandrabose, S.R., Evans, G., Thavamani, P., 2018. Transport and fate of microplastics in wastewater treatment plants: implications to environmental health. Rev. Environ. Sci. Bio/Technol. 17, 637-653. https://doi.org/10.1007/s11157-018-9480-3.

Rayne S., Wan, P., Ikonomou, M., 2006. Photochemistry of a major commercial polybrominated diphenyl ether flame retardant congener: 2,2',4,4',5,5'-hexabromodiphenyl ether (BDE153). Environ. Int. 32(5), 575-585. https://doi.org/10.1016/j.envint.2006.01.009.

Rauch, S., Morrison, G.M., 2008. Environmental relevance of the platinum-group elements. Elements. 4(4), 259-263. https://doi.org/10.2113/GSELEMENTS.4.4.259.

Reanzellitti, S., Canesi, L., Auguste, M., Wathsala, R. H. G. R., Fabbri, E., 2019. Microplastics exposure and effects in aquatic organisms: A physiological perspective. Environ. Toxicol. Pharmacol. 68, 37-51. https://doi.org/10.1016/j.etap.2019.03.009.

Redford, D.P., Trulli, H.K., Trulli, W.R., 1997. Sources of plastic pellets in the aquatic environment. In J.M. Coe and D.B. Rogers (Eds.), Marine Debris (pp. 335-343). Springer New York. https://doi.org/10.1007/978-1-4613-8486-1_30.

Reid, A.J., Carlson, A.K., Creed, I.F., Eliason, E.J., Gell, P.A., Johnson, P.T.J., Kidd, K.A., MacCormack, T.J., Olden, J.D., Ormerod, S.J., Smol, J.P., Taylor, W.W., Tockner, K., Vermaire, J.C., Dudgeon, D., Cooke, S.J., 2019. Emerging threats and persistent conservation challenges for freshwater biodiversity. Biol. Rev. 94(3), 849-873. https://doi.org/10.1111/brv.12480.

Reisser, J., Shaw, J., Wilcox, C., Hardesty, B.D., Proietti, M., Thums, M., Pattiaratchi, C., 2013. Marine plastic pollution in waters around Australia: Characteristics, concentrations, and pathways. PLoS ONE, 8(11), e80466. https://doi.org/10.1371/journal.pone.0080466. 
Reinholz, J., Diesler, C., Schöttler, S., Kokkinopoulou, M., Ritz, S., Landfester, K., Mailänder, V., 2018. Protein machineries defining pathways of nanocarrier exocytosis and transcytosis. Acta Biomater. 71, 432-443. https://doi.org/10.1016/j.actbio.2018.03.006.

Remy, F., Collard, F., Gilbert, B., Compère, P., Eppe, G., Lepoint, G., 2015. When microplastic is not plastic: The ingestion of artificial cellulose fibers by macrofauna living in seagrass macrophytodetritus. Environ. Sci. Technol. 49(18), 11158-11166. https://doi.org/10.1021/acs.est.5b02005.

Revel, M., Châtel, A., Mouneyrac, C., 2018. Micro(nano)plastics: A threat to human health? Curr. Opin. Environ. Sci. Health. 1, 17-23. https://doi.org/10.1016/j.coesh.2017.10.003.

Ribeiro, F., Garcia, A.R., Pereira, B.P., Fonseca, M., Mestre, N.C., Fonseca, T.G., Ilharco, L.M., Bebianno, M.J., 2017. Microplastics effects in Scrobicularia plana. Mar. Pollut. Bull. 122(1-2), 379-391. https://doi.org/10.1016/j.marpolbul.2017.06.078.

Ribic, C.A., Sheavly, S.B., Rugg, D.J., Erdmann, E.S., 2010. Trends and drivers of marine debris on the Atlantic coast of the United States 1997-2007. Mar. Pollut. Bull. 60(8), 1231-1242. https://doi.org/10.1016/j.marpolbul.2010.03.021.

Rillig, M.C., 2012. Microplastic in terrestrial ecosystems and the soil? Environ. Sci. Technol. 46(12), 6453-6454. https://doi.org/10.1021/es302011r.

Rios, L.M., Jones, P.R., Moore, C., Narayan, U.V., 2010. Quantitation of persistent organic pollutants adsorbed on plastic debris from the Northern Pacific Gyre's "eastern garbage patch". J. Environ. Monitor. 12(12), 2226-2236. https:/doi.org/10.1039/c0em00239a.

Rios, L.M., Moore, C., Jones, P.R., 2007. Persistent organic pollutants carried by synthetic polymers in the ocean environment. Mar. Pollut. Bull. 54(8), 1230-1237.

htpps://doi.org/10.1016/j.marpolbul.2007.03.022.

Rist, S.E., Assidiqi, K., Zamani, N.P., Appel, D., Perschke, M., Huhn, M., Lenz, M., 2016. Suspended micro-sized PVC particles impair the performance and decrease survival in the Asian green mussel Perna viridis, 111, 213-220. https//doi.org/10.1016/j.marpolul.2016.07.006.

Rochman, C.M., Hoh, E., Kurobe, T., Teh, S.J., 2013a. Ingested plastic transfers hazardous chemicals to fish and induces hepatic stress. Sci. Rep. 3(1), 3263. https://doi.org/10.1038/srep03263. 
Rochman, C.M., Manzano, C., Hentschel, B.T., Simonich, S.L.M., Hoh, E., 2013b. Polystyrene plastic: a source and sink for polycyclic aromatic hydrocarbons in the marine environment. Environ. Sci. Technol. 47, 13976-13984. https://doi.org/10.1021/es403605f.

Rochman, C.M., Kurobe, T., Flores, I., The, S.J. 2014a. Early warning signs of endocrine disruption in adult fish from the ingestion of polyethylene with and without sorbed chemical pollutants from the marine environment. Sci. Total Environ. 493, 656-661. https://doi.org/10.1016/j.scitotenv.201.06.051.

Rochman, C.M., Lewison, R.L., Eriksen, M., Allen, H., Cook, A., Teh, S.J., 2014b. Polybrominated diphenyl ethers (PBDEs) in fish tissue may be an indicator of plastic contamination in marine habitats. Sci. Total Environ. 477, 622-633. https://doi.org/10.1016/j.scitotenv.2014.01.058.

Rochman, C., Tahir, A., Williams, S., Baxa, D.V., Lam, R., Miller, J.T., Teh, F.-C., Weroilangi, S., Teh, S., 2015. Anthropogenic debris in seafood: Plastic debris and fibers from textiles in fish and bivalves sold for human consumption. Sci. Rep. 5, 14340. https://doi.org/10.1038/srep14340

Rochman, C.M., Cook, A.-M., Koelmans, A.A., 2016. Plastic debris and policy: Using current scientific understanding to invoke positive change: Plastic debris and policy. Environ. Toxicol. Chem. 35(7), 1617-1626. https://doi.org/10.1002/etc.3408.

Rochman, C.M., Browne, M.A., Underwood, A.J., van Franeker, J.A., Thompson, R.C., Amaral-Zettler, L.A., 2016. The ecological impacts of marine debris: Unraveling the demonstrated evidence from what is perceived. Ecol. 97(2), 302-312. https://doi.org/10.1890/14-2070.1.

Rochman, C.M., Parnis, J.M., Browne, M.A., Serrato, S., Reiner, E.J., Robson, M., Young, T., Diamond, M.L., Teh, S.J., 2017. Direct and indirect effects of different types of microplastics on freshwater prey (Corbicula fluminea) and their predator (Acipenser transmontanus). PLoS ONE, 12(11), e0187664. https://doi.org/10.1371/journal.pone.0187664.

Romeo, T., Pietro, B., Pedà, C., Consoli, P., Andaloro, F., Fossi, M.C., 2015. First evidence of presence of plastic debris in stomach of large pelagic fish in the Mediterranean Sea. Mar. Pollut. Bull. 95(1), 358-361. https://doi.org/10.1016/j.marpolbul.2015.04.048. 
Rummel, C.D., Löder, M.G.J., Fricke, N.F., Lang, T., Griebeler, E.-M., Janke, M., Gerdts, G., 2016. Plastic ingestion by pelagic and demersal fish from the North Sea and Baltic Sea. Mar. Pollut. Bull. 102(1), 134-141. https://doi.org/10.1016/j.marpolbul.2015.11.043.

Rothstein, S.I., 1973. Particle pollution of the surface of the Atlantic Ocean: Evidence from a seabird. Condor, 73, 344-345. https://doi.org/10.2307/1366176.

Rubio, L., Marcos, R., Hernández, A., 2020. Potential adverse health effects of ingested micro- and nanoplastics on humans. Lessons learned from in vivo and in vitro mammalian models. J. Toxicol. Env. Health B. 23(2), 51-68. https://doi.org/10.1080/10937404.2019.1700598.

Rusina, T.P., Smedes, F., Klanova, J., 2010. Diffusion coefficients of polychlorinated biphenyls and polycyclic aromatic hydrocarbons in polydimethylsiloxane and low-density polyethylene polymers. J. App. Polym. Sci,, NA-NA. https://doi.org/10.1002/app.31704.

Ruttkies, C., Schymanski, E.L., Wolf, S., Hollender, J., Neumann, S., 2016. MetFrag relaunched: incorporating strategies beyond in silico fragmentation. J. Cheminform. 8, 3. https://doi.org/10.1186/s13321-016-0115-9.

Ryan, P.G., 1987. The incidence and characteristics of plastic particles ingested by seabirds. Mar. Environ. Res. 23(3), 175-206. https://doi.org/10.1016/0141-1136(87)90028-6.

Ryan, P.G., 2013. A simple technique for counting marine debris at sea reveals steep litter gradients between the Straits of Malacca and the Bay of Bengal. Mar. Pollut. Bull. 69(1), 128-136. https://doi.org/10.1016/j.marpolbul.2013.01.016.

Sanchez-Vidal, A., Canals, M., Calafat, A.M., Lastras, G., Pedrosa-Paimes, R., Menendez, M., Medina, R., Company, J.B., Hereu, B., Romero, J., Alcoverri, T., 2012. Impacts on the deep-sea ecosystem by a severe coastal storm. PLoS One. 7(1), e30395. https://doi:10.1371/journal.pone.0030395.

Sánchez de Medina, F., Romero-Calvo, I., Mascaraque, C., Martínez-Augustin, O., 2014. Intestinal inflammation and mucosal barrier function. Inflamm. Bowel. Dis. 20(12), 2394-2404. https://doi.org/10.1097/MIB.0000000000000204. 
Santana, M.F.M., Moreira, F.T., Turra, A., 2017. Trophic transference of microplastics under a low exposure scenario: Insights on the likelihood of particle cascading along marine food-webs. Mar. Pollut. Bull. 121(1-2), 154-159. https://doi.org/10.1016/j.marpolbul.2017.05.061.

Savoca, M.S., Wohlfeil, M.E., Ebeler, S.E., Nevitt, G.A., 2016. Marine plastic debris emits a keystone infochemical for olfactory foraging seabirds. Sci. Adv. 2(11), e1600395. https://doi.org/10.1126/sciadv.1600395.

Sawada, H., 1998. ISO standard activities in standardization of biodegradability of plastics - development of test method and definitions. Polym. Degrad. Stab. 59, 365-370. https://doi.org/10.1016/S01413910(97)00191-2.

Schmidt, C., Lautenschlaeger, C., Collnot, E.-M., Schumann, M., Bojarski, C., Schulzke, J.-D., Lehr, C.M., Stallmach, A., 2013. Nano- and microscaled particles for drug targeting to inflamed intestinal mucosa-A first in vivo study in human patients. J. Control Release. 165(2), 139-145. https://doi.org/10.1016/j.jconrel.2012.10.019.

Schlining K., Thun, S., Kuhnz, L., Schlining, B., Lundsten, L., Jacobsen Stout, ... Connor, J., 2013. Debris in the deep: using a 22-year video annotation database to survey marine litter in Monterey Canyon, central California, USA. Deep-Sea Research. Part II: Topical Studies in Oceanography, 79, 96-105. https://doi.org/10.1016/j.dsr.2013.05.006.

Schuyler, Q.A., Wilcox, C., Townsend, K.A., Wedemeyer-Strombel, K.R., Balazs, G., van Sebille, E., Hardesty, B.D., 2015. Risk analysis reveals global hotspots for marine debris ingestion by sea turtles. Glob. Chang. Biol. 22(2), 567-576. https://doi.org/10.1111/gcb.13078.

Scott, G., 1999. Roy. Soc. Chem: Polymers and the environment. https://doi.org/10.1039/9781847551726.

Scott, G., Gilead, D., 1995. Degradable polymers: principles and applications. Kluwer Academic Publishers/Chapman and Hall.

Selck, H., Handy, R.D., Fernandes, T.F. Klaine, S.J., Petersen, E.J. 2016. Nanomaterials in the aquatic environment: A European Union-United States perspective on the status of ecotoxicity testing, research priorities, and challenges ahead. Environ. Toxicol. Chem. 35, 1055-1067. https://doi.org/10.1002/etc.3385. 
Selke, S., 1996. Biodegradation and packaging. $2^{\text {nd }}$ ed. Pira International Reviews.

Serrano, R., Nácher-Mestre, J., Portolés, T., Amat, F., Hernández, F., 2011. Non-target screening of organic contaminants in marine salts by gas chromatography coupled to high-resolution time-offlight mass spectrometry. Talanta, 85(2), 877-884. https://doi.org/10.1016/j.talanta.2011.04.055.

Setälä, O., Magnusson, K., Lehtiniemi, M., Norén, F., 2016. Distribution and abundance of surface water microlitter in the Baltic Sea: A comparison of two sampling methods. Mar. Pollut. Bull. 110 (1), 177-183. https://doi.org/10.1016/j.marpolbul.2016.06.065.

Sharma, H.B., Vanapalli, K.R., Cheela, V.S., Ranjan, V.P., Jaglan, A.K., Dubey, B., Goel, S., Bhattacharya, J., 2020. Challenges, opportunities, and innovations for effective solid waste management during and post COVID-19 pandemic. Resour. Conserv. Recy. 162, 105052. https://doi.org/10.1016/j.resconrec.2020.105052.

Shaw, D.G., Day, R.H., 1994. Colour- and form-dependent loss of plastic micro-debris from the North Pacific Ocean, Marine Pollution Bulletin, 28 (1), 39-43, https://doi.org/10.1016/0025326X(94)90184-8.

Sherman, P., Sebille, E. van., 2016. Modeling marine surface microplastic transport to assess optimal removal locations. Environ. Res. Lett. 11(1), 014006. https://doi.org/10.1088/17489326/11/1/014006.

Siddiqi, M.A., Laessig, R.H., Reed, K.D., 2003. Polybrominated diphenyl ethers (PBDEs): New pollutantsold diseases. J. Clin. Med. Res. 1(4), 281-290. https://doi.org/10.3121/cmr.1.4.281.

Sienra, M.R., 2006. Oxygenated polycyclic aromatic hydrocarbons in urban air particulate matter. Atmos. Environ. 40(13), 2374-2384. https://doi.org/10.1016/j.atmosenv.2005.12.009

Singh, Z., Bhalla, S., 2017. Toxicity of synthetic fibres \& health. Adv. Res. Text. Eng. 2(1), 1012. https://doi.org/10.26420/advrestexteng.2017.1012.

Smedes, F., Geertsma, R.W., van der Zande, T., Booij, K., 2009. Polymer-water partition coefficients of hydrophobic compounds for passive sampling: Application of cosolvent models for validation. Environ. Sci. Technol. 43(18), 7047-7054. htpps://doi.org/10.1021/es9009376. 
Soclo, H.H., Garrigues, P., Ewald, M., 2000. Origin of polycyclic aromatic hydrocarbons (PAHs) in coastal marine sediments: Case studies in Cotonou (Benin) and Aquitaine (France) areas. Mar. Pollut. Bull. 40(5), 387-396. https://doi.org/10.1016/S0025-326X(99)00200-3.

Song, J.H., Murphy, R.J., Narayan, R., Davies, G.B.H., 2009. Biodegradable and compostable alternatives to conventional plastics. Phil. Trans. R. Soc. B. 364, 2127-2139 https://doi.org/10.1098/rstb.2008.0289.

Song, Y.K., Hong, S.H., Jang, M., Kang, J.-H., Kwon, O.Y., Han, G.M., Shim, W.J., 2014. Large accumulation of micro-sized synthetic polymer particles in the sea surface microlayer. Environ. Sci. Technol. 48(16), 9014-9021. https://doi.org/10.1021/es501757s.

Song, Y.K., Hong, S.H., Jang, M., Han, G.M., Shim, W.J., 2015. Occurrence and distribution of microplastics in the sea surface microlayer in Jinhae Bay, South Korea. Arch. Environ. Con. Tox. 69(3), 279-287. https://doi.org/10.1007/s00244-015-0209-9.

Soni, D., Naoghare, P.K., Saravanadevi, S., Pandey, R.A. 2015. Release, transport and toxicity of engineered nanoparticles. In: Whitacre, D.M. (Ed.), Rev. Environ. Contam. T., Vol 234. Switzerland: Springer International Publishing, 1-48.

Spedicato, M.T., Zupa, W., Carbonara, P., Fiorentino, F., Follesa, M.C., Galgani, F., García-Ruiz, C., Jadaud, A., loakeimidis, C., Lazarakis, G., Lembo, G., Mandic, M., Maiorano, P., Sartini, M., Serena, F., Cau, A., Esteban, A., Isajlovic, I., Micallef, R., Thasitis, I., 2020. Spatial distribution of marine macro-litter on the seafloor in the northern Mediterranean Sea: The MEDITS initiative. Scientia Marina, 83(S1), 257. https://doi.org/10.3989/scimar.04987.14A.

Spengler, A., Costa, M.F., 2008. Methods applied in studies of benthic marine debris. Mar. Pollut. Bull. 56(2), 226-230. https://doi.org/10.1016/j.marpolbul.2007.09.040.

Spitz S.L., 1985. Chemicals in PCB Manufacturing. In: Riley, F. (Eds.), The Electronics Assembly Handbook. Springer, Berlin, Heidelberg. https://doi.org/10.1007/978-3-662-13161-9_5.

Stock, V., Böhmert, L., Lisicki, E., Block, R., Cara-Carmona, J., Pack, L.K., Selb, R., Lichtenstein, D., Voss, L., Henderson, C.J., Zabinsky, E., Sieg, H., Braeuning, A., Lampen, A., 2019. Uptake and effects of orally ingested polystyrene microplastic particles in vitro and in vivo. Arch. Toxicol. 93(7), 1817-1833. https://doi.org/10.1007/s00204-019-02478-7. 
Stefaniuk, M., Oleszczuk, P., Ok, Y.S., 2016. Review on nano zerovalent iron (nZVI): From synthesis to environmental applications. Chem. Eng. 287, 618-632. https://doi.org/10.1016/j.cej.2015.11.046.

Stefatos, A., Charalampakis, M., Papatheodorou, G., Ferentinos, G., 1999. Marine debris on the seafloor of the Mediterranean Sea: examples from two enclosed gulfs in Western Greece. Mar. Pollut. Bull. 36, 389-393. https://doi.org/10.1016/S0025-326X(98)00141-6.

Stegeman, J.J., Lech, J.J., 1991. Cytochrome P-450 monooxygenase systems in aquatic species: Carcinogen metabolism and biomarkers for carcinogen and pollutant exposure. Environ. Health Perspect. 90, 101-109. https://doi.org/10.1289/ehp.90-1519513.

Strungaru, S.A., Jijie, R., Nicoara, M., Plavan, G., Faggio, C., 2019. Micro (nano) plastics in freshwater ecosystems: abundance, toxicological impact and quantification methodology. Trends Analyt. Chem. 110, 116-128. https://doi.org/10.1016/j.trac.2018.10.025.

Su, L., Deng, H., Li, B., Chen, Q., Pettigrove, V., Wu, C., Shi, H., 2019. The occurrence of microplastic in specific organs in commercially caught fishes from coast and estuary area of east China. J. Hazard. Mater. 365, 716-724. https://doi.org/10.1016/j.jhazmat.2018.11.024.

Sussarellu, R., Suquet, M., Thomas, Y., Lambert, C., Fabioux, C., Pernet, M.E.J., ... Huvet, A., 2016. Oyster reproduction is affected by exposure to polystyrene microplastics. Proc. Natl. Aca. Sci. USA 113(9), 2430-2435. https://doi.org/10.1073/pnas.1519019113.

Sussarellu, R., Suquet, M., Thomas, Y., Lambert, C., Fabioux, C., Pernet, M.E.J., Le Goïc, N., Quillien, V., Mingant, C., Epelboin, Y., Corporeau, C., Guyomarch, J., Robbens, J., Paul-Pont, I., Soudant, P., Huvet, A., 2016. Oyster reproduction is affected by exposure to polystyrene microplastics. Proc. Natl. Aca. Sci. USA, 113(9), 2430-2435. https://doi.org/10.1073/pnas.1519019113.

Sykes, E., Dai, Q., Tsoi, K., Hwang, D.M., Chan, W.C.W., 2014. Nanoparticle exposure in animals can be visualized in the skin and analysed via skin biopsy. Nat. Commun. 5, 3796. https://doi.org/10.1038/ncomms4796.

Talley, L.D., 2002. Salinity patterns in the ocean. Wiley: Encyclopedia of global change, the earth system: Physical and chemical dimensions of global environmental change. pp. 629-640. https://www.wiley.com/enus/Encyclopedia+of+Global+Environmental+Change\%2C+Volume+2\%2C+The+Earth+System\% 
3A+Biological+and+Ecological+Dimensions+of+Global+Environmental+Change-p9780470853610.

Tanaka, K., Takada, H., 2016. Microplastic fragments and microbeads in digestive tracts of planktivorous fish from urban coastal waters. Sci. Rep. 6(1), 34351. https://doi.org/10.1038/srep34351.

Tanaka, K., Takada, H., Yamashita, R., Mizukawa, K., Fukuwaka, M., Watanuki, Y., 2013. Accumulation of plastic-derived chemicals in tissues of seabirds ingesting marine plastics. Mar. Pollut. Bull. 69(1-2), 219-222. https://doi.org/10.1016/j.marpolbul.2012.12.010.

Taylor, M.L., Gwinnett, C., Robinson, L.F., Woodall, L.C., 2016. Plastic microfibre ingestion by deep-sea organisms. Sci. Rep. 6(1), 33997. https://doi.org/10.1038/srep33997.

Tekman, M., Krumpen, T., Bergmann, M., 2017. Marine litter on deep Arctic seafloor continues to increase and spreads to the North at the HAUSGARTEN observatory. Deep Sea Research Part I: Oceanographic Research Papers, 120, 88-99. https://doi.org/10.1016/j.dsr.2013.05.006

Teuten, E.L., Rowland, S.J., Galloway, T.S., Thompson, R.C., 2007. Potential for plastics to transport hydrophobic contaminants. Environ. Sci. Technol. 41(22), 7759-7764. https://doi.org/10.1021/es071737s.

Teuten, E.L., Saquing, J.M., Knappe, D.R.U., Barlaz, M.A., Jonsson, S., Björn, A., Rowland, S. J., Thompson, R.C., Galloway, T.S., Yamashita, R., Ochi, D., Watanuki, Y., Moore, C., Viet, P.H., Tana, T.S., Prudente, M., Boonyatumanond, R., Zakaria, M.P., Akkhavong, K., Ogata, Y., Hirai, H., Iwas, S., Mizukawa, K., Hagino, Y., Imamura, A., Saha, M., Takada, H., 2009. Transport and release of chemicals from plastics to the environment and to wildlife. Philos. Trans. Roy. Soc. B, 364(1526), 2027-2045.

Thiel, M., Hinojosa, I., Vasquez, N., Macaya, E., 2003. Floating marine debris incoastal waters of the SEPacific (Chile). Mar. Pollut. Bull. 46, 224-231. https://doi.org/ 10.1016/s0025-326x(02)00365-x.

Thomas, P., Rahman, M.S., Khan, I.A. and Kummer, J.A., 2007. Widespread endocrine disruption and reproductive impairment in an estuarine fish population exposed to seasonal hypoxia. Proc. Royal Soc. B. 274(1626), 2693-2702. https://doi.org/10.1098/rspb.2007.0921. 
Thompson, R.C., Olsen, Y., Mitchell, R.P., Davis, A., Rowland, S.J., John, A.W.G., McGonigle, D., Russell, A.E., 2004. Lost at sea: where is all the plastic? Science 304(5672), 838. https://doi.org/10.1126/science.1094559.

Thornton, L., Jackson, N.L., 1998. Spatial and temporal variations in debris accumulation and composition on an estuarine shoreline, Cliffwood Beach, New Jersey, USA, Marine Pollution Bulletin, 36(9), 705-711. https://doi.org/10.1016/S0025-326X(98)00041-1.

Tourinho, P.S., Ivar do Sul, J.A., Fillmann, G., 2010. Is marine debris ingestion still a problem for the coastal marine biota of southern Brazil? Mar. Pollut. Bull. 60(3), 396-401. https://doi.org10.1016/j.marpolbul.2009.10.013.

Wagner, M., Scherer, C., Alvarez-Muñoz, D., Brennholt, N., Bourrain, X., Buchinger, S., Fries, E., Grosbois, C., Klasmeier, J., Marti, T., Rodriguez-Mozaz, S., Urbatzka, R., Vethaak, A. D., Winther-Nielsen, M., Reifferscheid, G., 2014. Microplastics in freshwater ecosystems: what we know and what we need to know. Environ. Sci. Eur. 26(1), 12. https://doi.org/10.1186/s12302014-0012-7.

Walczak A.P., Kramer E., Hendriksen P.J., Tromp P., Helsper J.P., van der Zande M., Rietjens I.M., Bouwmeester, H., 2015. Translocation of differently sized and charged polystyrene nanoparticles in in vitro intestinal cell models of increasing complexity. Nanotoxicology 9, 453-461. https://doi.org/10.3109/17435390.2014.944599.

Wang, J., Tan, Z., Peng, J., Qiu, Q., Li, M. ,2016. The behaviors of microplastics in the marine environment. Mar. Environ. Res. 113, 7-17. https://doi.org/10.1016/j.marenvres.2015.10.014.

Wang, R., Tang, T., Xie, J., Tao, X., Huang, K., Zou, M., Yin, H., Dang, Z., Lu, G., 2018. Debromination of polybrominated diphenyl ethers (PBDEs) and their conversion to polybrominated dibenzofurans (PBDFs) by UV light: Mechanisms and pathways. J. Hazard. Mater. 354, 1-7. https://doi.org/10.1016/j.jhazmat.2018.04.057.

Wang, Q.Y., Huang, R.J., Cao, J.J., Han, Y.M., Wang, G.H., Li, G.H., Wang, Y.C., Dai, W.T., Zhang, R.J., Zhou, Y.Q., 2014. Mixing state of black carbon aerosol in a heavily polluted urban area of China: implications for light absorption enhancement. Aerosol Sci. Technol. 48, 689-697. https://doi.org/10.1080/02786826.2014.917758, 201. 
Wang, J., Liu, L., Wang, J., Pan, B., Fu, X., Zhang, G., Zhang, L., Lin, K., 2015. Distribution of metals and brominated flame retardants (BFRs) in sediments, soils and plants from an informal e-waste dismantling site, South China. Environ. Sci. Pollut. Res. 22, 1020-1033. https://doi.org/10.1007/s11356-014-3399-1.

Wang, R., Tang, T., Wei, Y., Dang, D., Huang, K., Chen, X., Yin, H., Tao, X., Lin, Z., Dang, Z., Lu, G., 2019. Photocatalytic debromination of polybrominated diphenyl ethers (PBDEs) on metal doped TiO2 nanocomposites: Mechanisms and pathways. Environ. Inter. 127, 5-12. https://doi.org/10.1016/j.envint.2019.03.011.

Wardrop, P., Shimeta, J., Nugegoda, D., Morrison, P.D., Miranda, A., Tang, M., Clarke, B.O., 2016. Chemical pollutants sorbed to ingested microbeads from personal care products accumulate in fish. Environ. Sci. Technol. 50(7), 4037-4044. https://doi.org/10.1021/acs.est.5b06280.

Watanabe, I., Kashimoto, T., Tatsukawa, R., 1987. Polybrominated biphenyl ethers in marine fish, shellfish and river and marine sediments in Japan. Chemosphere 16(10), 2389-2396. https://doi.org/10.1016/0045-6535(87)90297-9.

Watts, A.J., Urbina, M.A., Corr, S., Lewis, C., Galloway, T.S., 2015. Ingestion of plastic microfibers by the crab Carcinus maenas and its effect on food consumption and energy balance. Environ. Sci. Technol. 49(24), 14597-14604. https://doi.org/10.1021/acs.est.5b04026.

Watts, A.J., Lewis, C., Goodhead, R.M., Beckett, S.J., Moger, J., Tyler, C.R., Galloway, TS., 2014. Uptake and retention of microplastics by the shore crab Carcinus maenas. Environ. Sci. Technol. 48(15), 8823-8830. https://doi.org/10.1021/es501090e.

Wegner, A., Besseling, E., Foekema, E.M., Kamermans, P., Koelmans, A.A., 2012. Effects of nanopolystyrene on the feeding behavior of the blue mussel (Mytilus edulis L.). Environ. Toxicol. Chem. 31(11), 2490 -2497. https://doi.org/10.1002/etc.1984.

Welden, N.A.C., Cowie, P.R., 2016. Environment and gut morphology influence microplastic retention in langoustine, Nephrops norvegicus. Environ. Pollut. 214, 859-865. https://doi.org/10.1016/j.envpol.2016.03.067. 
Westernhoff, P., Nowack, B., 2013. Searching for global descriptors of engineered nanomaterial fate and transport in the environment. Accounts Chem Res. 46, 844-853. https://doi.org/10.1021/ar300030n.

Wiesner, M.R., Lowry, G.V., Casman, E., Bertsch, P.M., Matson, C.W., Di Giulio, R.T., Liu, J., Hochella, M.F., 2011. Meditations on the ubiquity and mutability of nano-sized materials in the environment. ACS Nano, 5(11), 8466-8470. https://doi.org/10.1021/nn204118p.

Wilcox, C., Puckridge, M., Schuyler, Q.A., Townsend, K.A., 2018. A quantitative analysis linking sea turtle mortality and plastic debris ingestion. Sci. Rep. 8, 12536. https://doi.org/10.1038/s41598-01830038-z.

Windsor, F.M., Pereira, M.G., Tyler, C.R., Ormerod, S.J., 2019. Persistent contaminants as potential constraints on the recovery of urban river food webs from gross pollution. Water Res. 163, 114858. https://doi.org/10.1016/j.watres.2019.114858.

World Health Organization (WHO), 1994. EHC \#162 Geneva. http://www.inchem.org/documents/ehc/ehc/ehc162.htm.

White, M., Bashmachnikov, I., Arístegui, J., Martins, A., 2007. Physical processes and seamount productivity. In T.J. Pitcher, T. Morato, P.J.B. Hart, M.R. Clark, N. Haggan, and R.S. Santos (Eds.), Seamounts: Ecology, Fisheries \& Conservation (pp. 65-84). Oxford, UK: Blackwell Publishing. https://doi.org/10.1002/9780470691953.ch4

Williams, A.T., Rangel-Buitrago, N., 2019. Marine litter: Solutions for a major environmental problem. J. Coast. Res. 35(3), 648. https://doi.org/10.2112/JCOASTRES-D-18-00096.1.

Williams, A.T., Tudor, D.T. 2001. Litter burial and exhumation: spatial and temporal distribution on a cobble pocket beach. Mar. Pollut. Bull. 42(11), 1031-1039. https://doi.org/10.1016/S0025326X(01)00058-3.

Woodall, L.C., Sanchez-Vidal, A., Canals, M., Paterson, G.L.J., Coppock, R., Sleight, V., Calafat, A., Rogers, A.D., Narayanaswamy, B.E., Thompson R.C., 2014. The deep sea is a major sink for microplastic debris. R. Soc. Open Sci. 1, 140317. https://doi.org/10.1098/rsos.140317.

Wright, S.L., Kelly, F.J., 2017. Plastic and human health: A micro issue? Environ. Sci. Technol. 51(12), 6634-6647. https://doi.org/10.1021/acs.est.7b00423. 
Wright, S.L., Rowe, D., Thompson, R.C., Galloway, T.S., 2013a. Microplastic ingestion decreases energy reserves in marine worms. Curr. Biol. 23(23), R1031-R1033. https://doi.org/10.1016/j.cub.2013.10.068.

Wright, S.L., Thompson, R.C., Galloway, T.S., 2013b. The physical impacts of microplastics on marine organisms: A review. Environ. Pollut. 178, 483-492. https://doi.org/10.1016/j.envpol.2013.02.031.

Woods, M.N., Stack, M.E., Fields, D.M., Shaw, S.D., Matrai, P.A., 2018. Microplastic fiber uptake, ingestion, and egestion rates in the blue mussel (Mytilus edulis). Mar. Pollut. Bull. 137, 638-645. https://doi.org/10.1016/j.marpolbul.2018.10.061.

Woodall, L.C., Sanchez-Vidal, A., Canals, M., Paterson, G.L.J., Coppock, R., Sleight, V., Calafat, A., Rogers, A.D., Narayanaswamy, B.E., Thompson, R.C., 2014. The deep sea is a major sink for microplastic debris. Roy. Soc. Open Sci. 1(4), 140317. https://doi.org/10.1098/rsos.140317.

Wu, Q., Tao, H., Wong, M.H., 2019. Feeding and metabolism effects of three common microplastics on Tenebrio molitor L. Environ. Geochem. Health, 41, 17-26. https://doi.org/10.1007/s10653-0180161-5.

Uhrin, A.V., Walsh, W.A. Brodziak, J., 2020. Relative abundance of derelict fishing gear in the Hawaiibased pelagic longline fishery grounds as estimated from fishery observer data. Sci. Rep. 10, 7767. https://doi.org/10.1038/s41598-020-64771-1

UN Environment, 2018. Single-Use Plastics: A Roadmap for Sustainability, United Nations Environment, Nairobi.

https://wedocs.unep.org/bitstream/handle/20.500.11822/25496/singleUsePlastic_sustainability.pd f.

van Cauwenberghe, L., Vanreusel, A., Mees, J., Janssen, C.R., 2013. Microplastic pollution in deep-sea sediments. Environ. Pollut. 182, 495-499. https://doi.org/10.1016/j.envpol.2013.08.013.

van Cauwenberghe, L., Janssen, C.R., 2014. Microplastics in bivalves cultured for human consumption. Environ. Pollut. 193, 65-70. https://doi.org/10.1016/j.envpol.2014.06.010.

van Cauwenberghe, L., Claessens, M., Vandegehuchte, M.B., Janssen, C.R., 2015. Microplastics are taken up by mussels (Mytilus edulis) and lugworms (Arenicola marina) living in natural habitats. Environ. Pollut., 199, 10-17. https://doi.org/10.1016/j.envpol.2015.01.008. 
van Franeker, J.A., Blaize, C., Danielsen, J., Fairclough, K., Gollah, J., Guse, N., Hansen, P.-L., Heubeck, M., Jensen, J.-K., Le Guillou, G., Olsen, B., Olsen, K.-O., Pedersen, J., Stienen, E.W.M., Turner, D.M., 2011. Monitoring plastic ingestion by the northern fulmar Fulmarus glacialis in the North Sea. Environ. Pollut. 159(10), 2609-2615. https://doi.org/10.1016/j.envpol.2011.06.008.

van Sebille, E., Wilcox, C., Lebreton, L., Maximenko, N., Hardesty, B.D., van Franeker, J.A., ... Law, K.L., 2015. A global inventory of small floating plastic debris. Environ. Res. Lett. 10, 124006. https://doi.org/10.1088/1748-9326/10/12/124006.

Verschoor, A., de Poorter, L., Dröge, R., Kuenen, J., de Valk, E., 2016. Emission of microplastics and potential mitigation measures: Abrasive cleaning agents, paints and tyre wear - RIVM Report 2016-0026. National Institute for Public Health and the Environment - Ministry of Health, Welfare and Sport. https://www.rivm.nl/bibliotheek/rapporten/2016-0026.pdf

Vert, M., Fejen, J., Albertsson, A-C., Scott, G., Chiellini, E., 1994. Wiley: Polymer International, Biodegradable polymers and plastics, 33(4). https://doi.org/10.1002/pi.1994.210330418.

Velzeboer, I., Kwadijk, C.J.A.F., Koelmans, A.A., 2014. Strong Sorption of PCBs to nanoplastics, microplastics, carbon nanotubes, and fullerenes. Environ. Sci. Technol. 48 (9), 4869-4876. https://doi.org/10.1021/es405721v.

Viršek, M. K., Palatinus, A., Koren, Š., Peterlin, M., Horvat, P., Kržan, A., 2016. Protocol for microplastics sampling on the sea surface and sample analysis. J. Visual. Exper. 118, 55161. https://doi.org/10.3791/55161

von Moos, N., Burkhardt-Holm, P., Köhler, A., 2012. Uptake and effects of microplastics on cells and tissue of the blue mussel Mytilus edulis L. after an experimental exposure. Environ. Sci. Technol. 46(20), 11327-11335. https://doi.org/10.1021/es302332w.

Yang, D., Shi, H., Li, L., Li, J., Jabeen, K., Kolandhasamy, P., 2015. Microplastic Pollution in Table Salts from China. Environ. Sci. Technol. 49(22), 13622-13627. https://doi.org/10.1021/acs.est.5b03163.

Yousif, E., Haddad, R., 2013. Photodegradation and photostabilization of polymers, especially polystyrene: review. SpringerPlus, 2, 398. https://doi.org/10.1186/2193-1801-2-398 
Zabaniotou, A., Kassidi, E., 2003. Life cycle assessment applied to egg packaging made from polystyrene and recycled paper. J. Clean. Prod. 11(5), 549-559. https://doi.org/10.1016/S09596526(02)00076-8.

Zalasiewicz, J., Waters, C.N., Ivar do Sul, J.A., Corcoran, P.L., Barnosky, A.D., Cearreta, A., ... Yonan, Y., 2016. The geological cycle of plastics and their use as a stratigraphic indicator of the Anthropocene. Anthropocene, 13, 4-17. https://doi.org/10.1016/j.ancene.2016.01.002

Zettler, E.R., Mincer, T.J., Amaral-Zettler, L., 2013. Life in the "plastiphere": microbial communities on plastic marine debris. Environ. Sci. Technol. 47, 7137-7146. https://doi.org/10.1021/es401288x

Zhang, R., Silic, M. R., Schaber, A., Wasel, O., Freeman, J. I., Sepulveda, M.S., 2020. Exposure route affects the distribution and toxicity of polystyrene nanoplastics in zebrafish. Sci. Total Environ. 724, 138065. https://doi.org/10.1016/j.scitotenv.2020.138065.

Zhao, S., Zhu, L., Wang, T., Li, D., 2014. Suspended microplastics in the surface water of the Yangtze Estuary System, China: First observations on occurrence, distribution. Mar. Pollut. Bull. 86(1-2), 562-568. https://doi.org/10.1016/j.marpolbul.2014.06.032.

Ziccardi, L.M., Edgington, A., Hentz, K., Kulacki, K.J., Kane Driscoll, S., 2016. Microplastics as vectors for bioaccumulation of hydrophobic organic chemicals in the marine environment: A state-of-thescience review. Environ. Toxicol. Chem. 35(7), 1667-1676. https://doi.org/10.1002/etc.3461.

Zink, T., Geyer, R., 2017. Circular economy rebound: circular economy rebound. J. Ind. Ecol. 21(3), 593602. https://doi.org/10.1111/jiec.12545.

Zitko, V., Hanlon, M., 1991. Another source of pollution by plastics: Skin cleaners with plastic scrubbers. Mar. Pollut. Bull. 22(1), 41-42. https://doi.org/10.1016/0025-326X(91)90444-W.

Zubris, K.A.V., Richards, B.K., 2005. Synthetic fibers as an indicator of land application of sludge. Environ. Pollut. 138(2), 201-211. https://doi.org/10.1016/j.envpol.2005.04.013

Zhu, D., Chen, Q.-L., An, X.-L., Yang, X.-R., Christie, P., Ke, X., Wu, L.-H., Zhu, Y.-G., 2018. Exposure of soil collembolans to microplastics perturbs their gut microbiota and alters their isotopic composition. Soil Biol. Biochem. 116, 302-310. https://doi.org/10.1016/j.soilbio.2017.10.027. 
Zhuang, Y., Ahn, S., Luthy, R.G., 2010. Debromination of polybrominated diphenyl ethers by nanoscale zerovalent iron: Pathways, kinetics, and reactivity. Environ. Sci. Technol. 44, 8236-8242. https:/doi.org/10.1021/es101601s. 


\section{Figure legends}

Fig. 1. Predicted global production of plastics over the last decade. Different sources of plastics in Asia, Africa, Australia, Europe, North America, and South America were documented as production (metric tons per/year), abundance (items $/ \mathrm{km}^{2}$ ) or volume (i.e., items $/ \mathrm{m}^{3}$ ) (Supplementary Table 1). EU, European Union; Gr, Germany; UK, United Kingdom; It, Italy; Fr, France; US, United States; Mx, Mexico; Eg, Egypt; SA, South Africa; Ni, Nigeria; Al, Algeria; Mo, Morocco; Ag, Argentina; Br, Brazil; In, India; Ch, China; Id, Indonesia; Th, Thailand; SK, South Korea; Pk, Pakistan; Ph, Philippines; Vt, Vietnam; Mi, Malaysia; NK, North Korea. M, million; yr, year. 
Figure 1

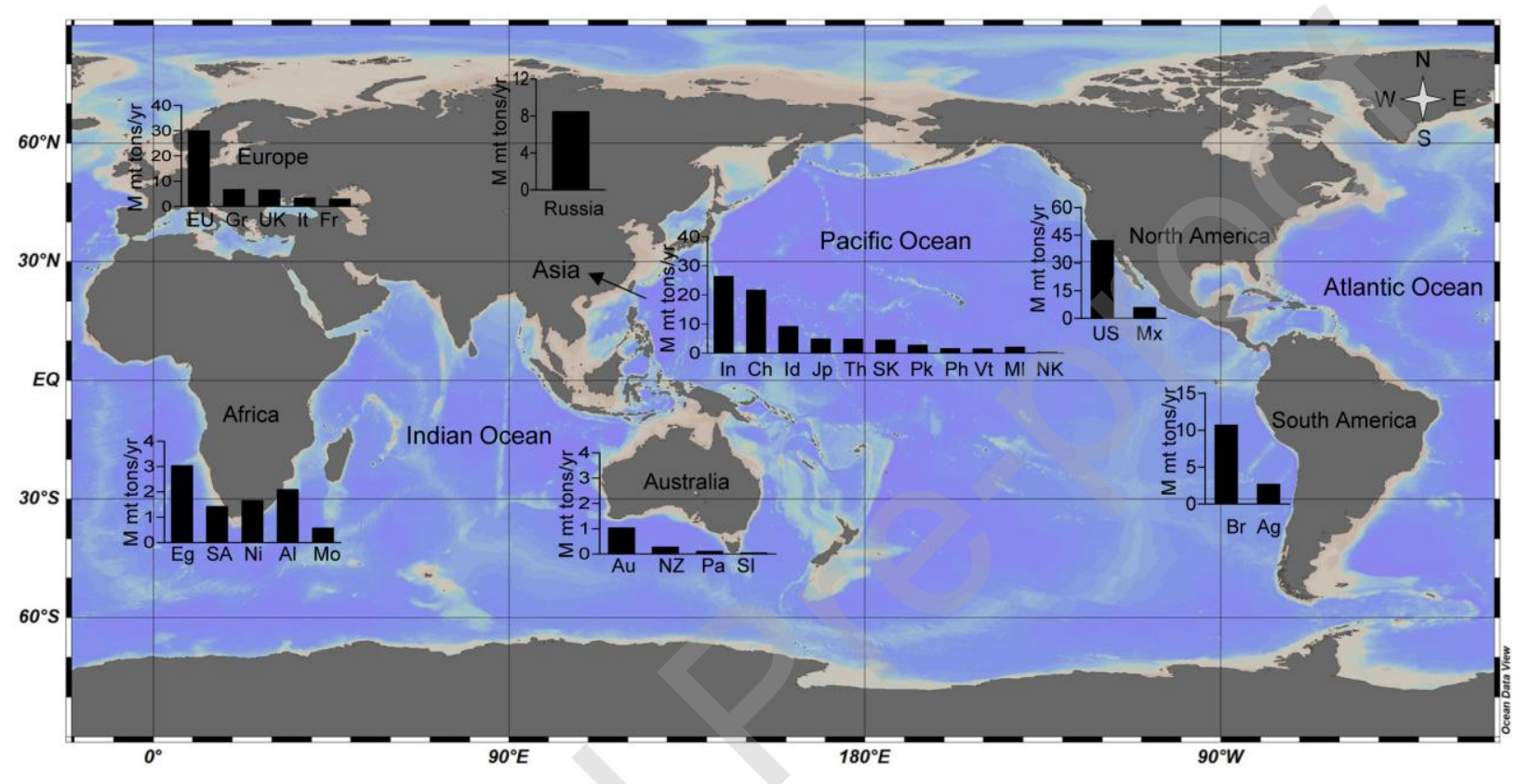


Fig. 2. Observed major debromination pathways of polybrominated diphenyl ethers (PBDEs). (A, B) Freshwater river in Bangladesh (Southeast Asia); (C) Sea shore in Texas Gulf coast (North America); (D) Possible debromination pathways of BDE-47 contained in microplastics found in aquatic environments. Bioaccumulation of BDE-28 and BDE-47 in aquatic organisms (e.g., D-a: sea urchin, an edible marine echinoid; D-b: sea urchin gonad, D-c: seaweed and sea urchin eggs, also called Japanese sushi). The chemical stress induced by xenobiotics in the environment favor the debromination of BDE-47 via hydrogen transfer mechanism at the ortho-position $(\Delta H=-1,164.029 \mathrm{~kJ} / \mathrm{mol})$, whereas electron transfer via nucleophilic attack at the para-position $(\Delta H=-1,232.342 \mathrm{~kJ} / \mathrm{mol})$ due to heat waves or global warming by elevated freshwater and/or sea surface temperatures, according to energy requirements (Supplementary Table 2). $\delta+$, positive electrostatic potential; $\delta$-, negative electrostatic potential; $\Delta H$, enthalpy change; $\varphi$, potential energy. 
Figure 2
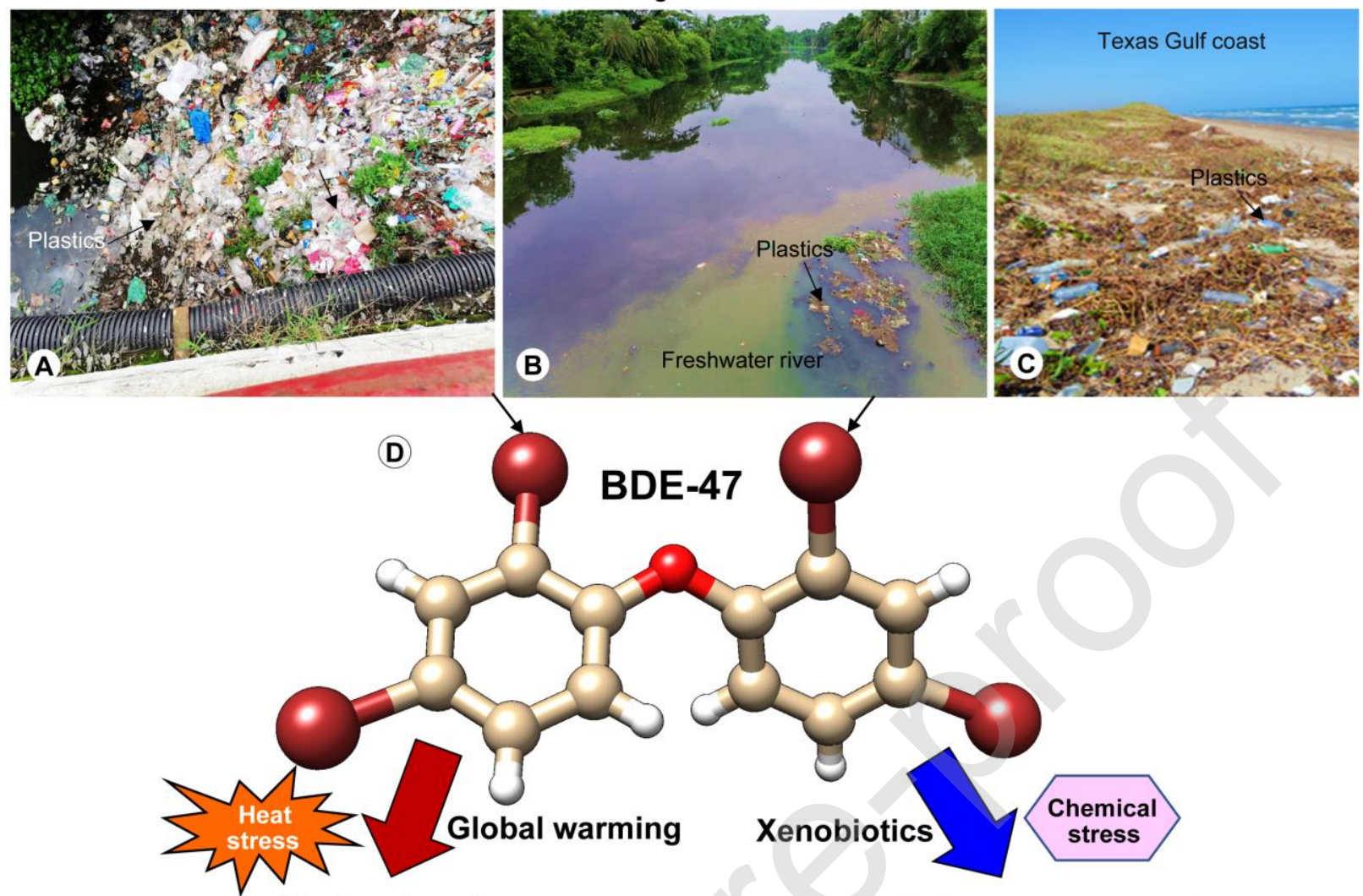

Electron transfer
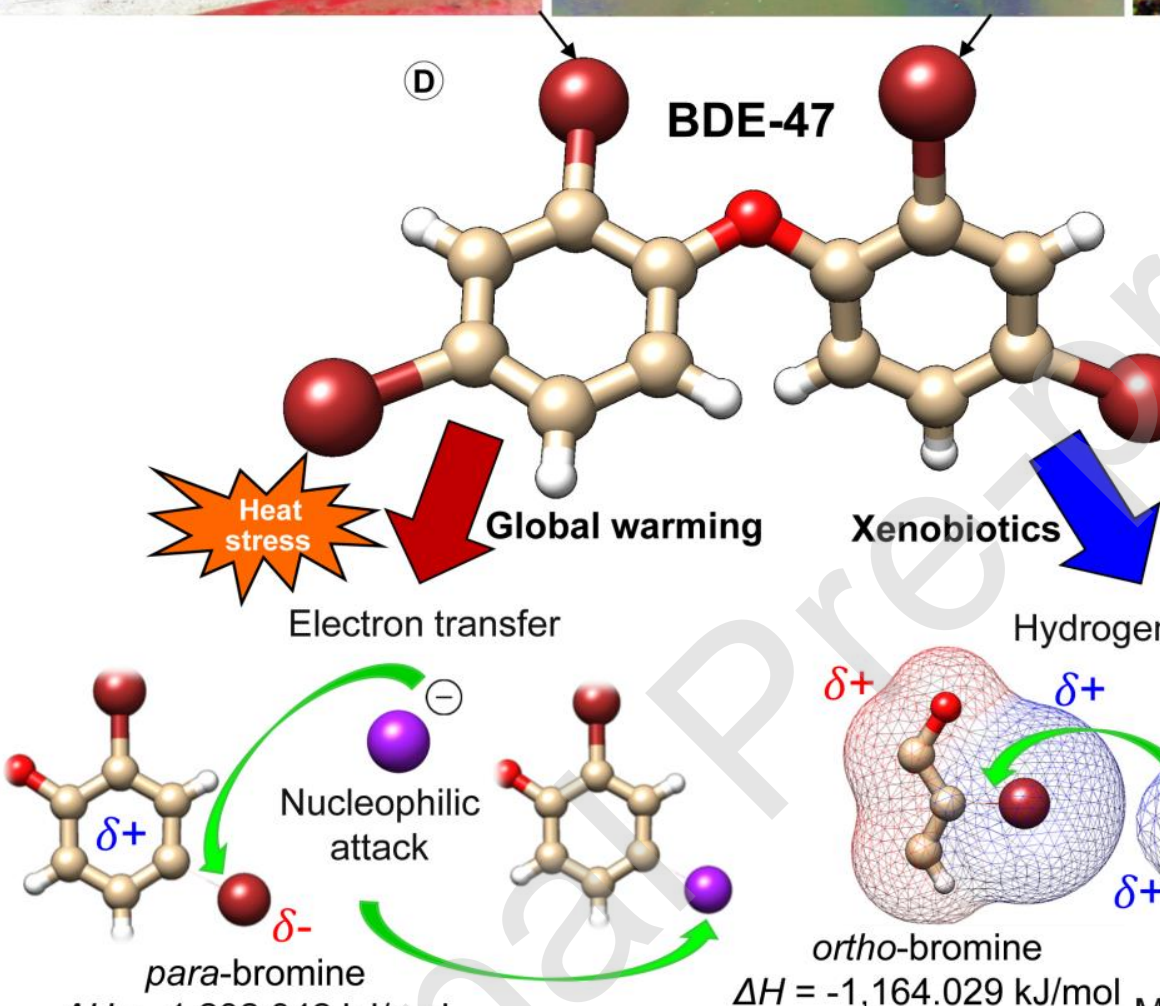

$\Delta H=-1,232.342 \mathrm{~kJ} / \mathrm{mol}$

$\Delta H=-1,164.029 \mathrm{~kJ} / \mathrm{mol}$ Metallic aggregate

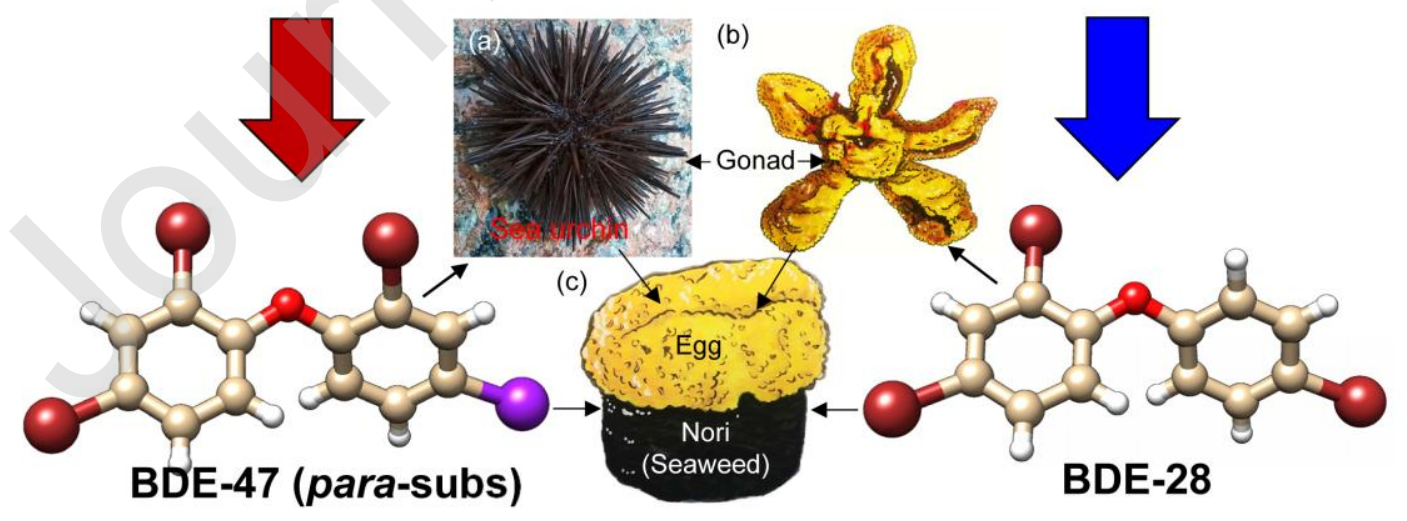




\section{Table 1}

Categorization plastic debris.

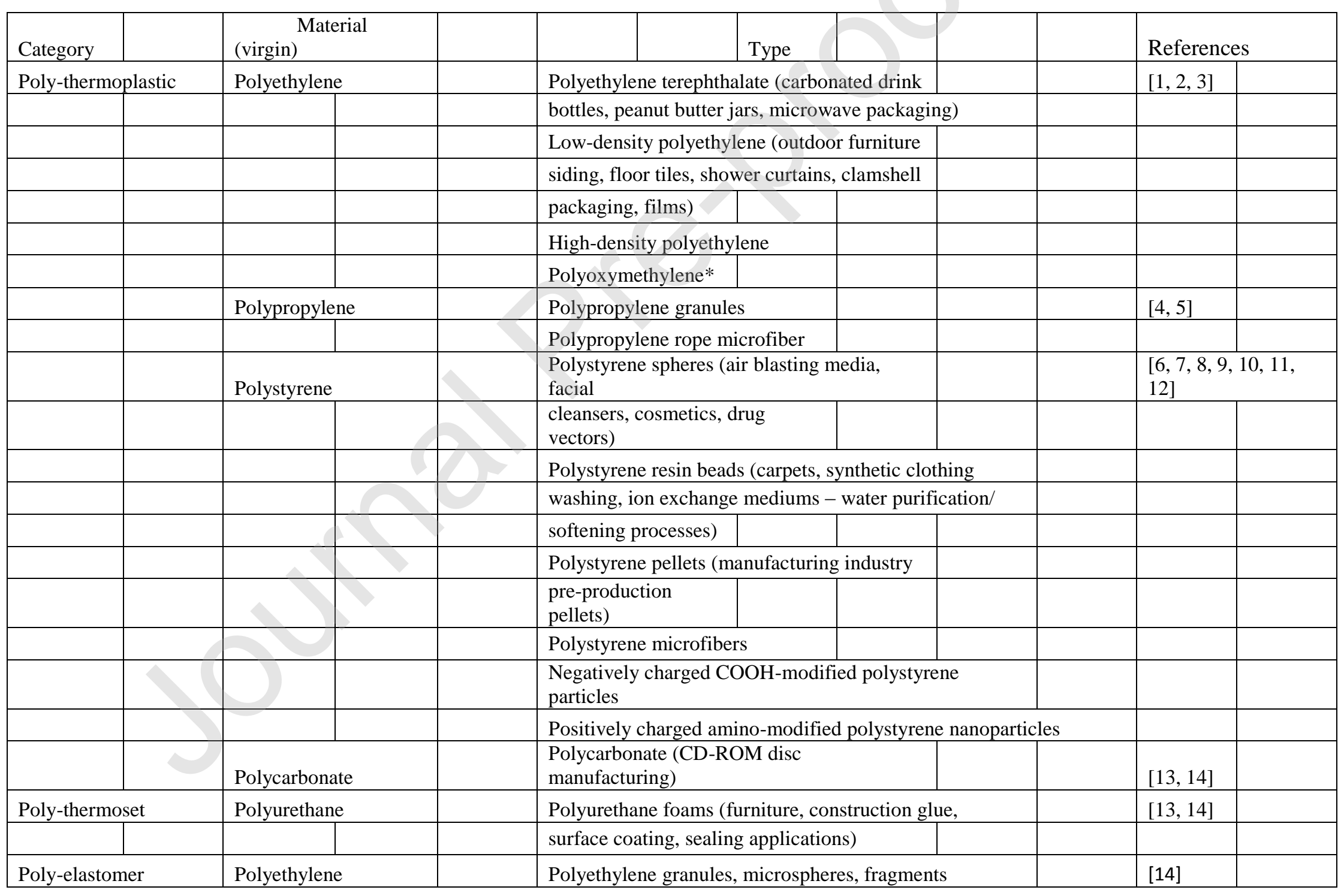




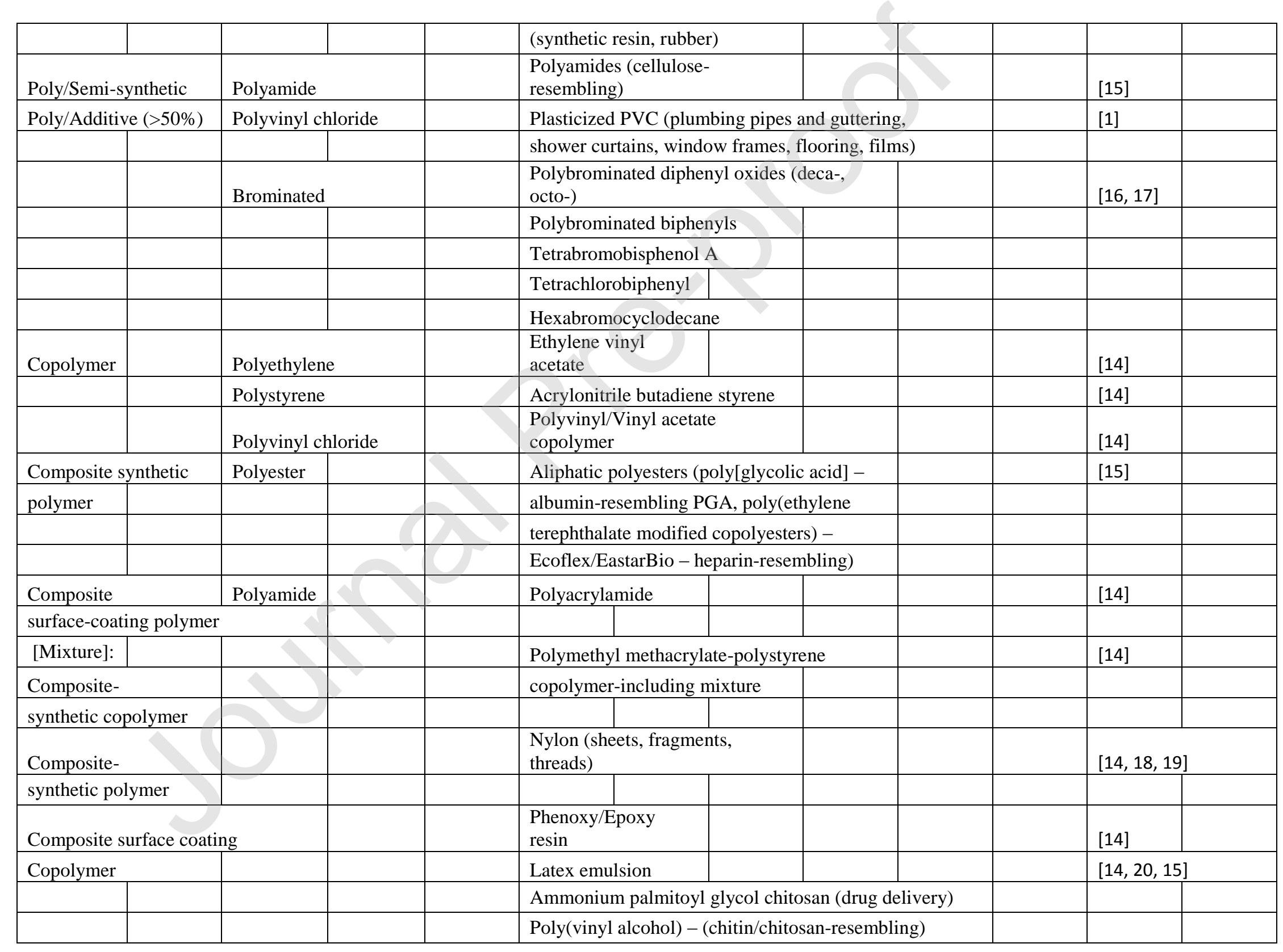




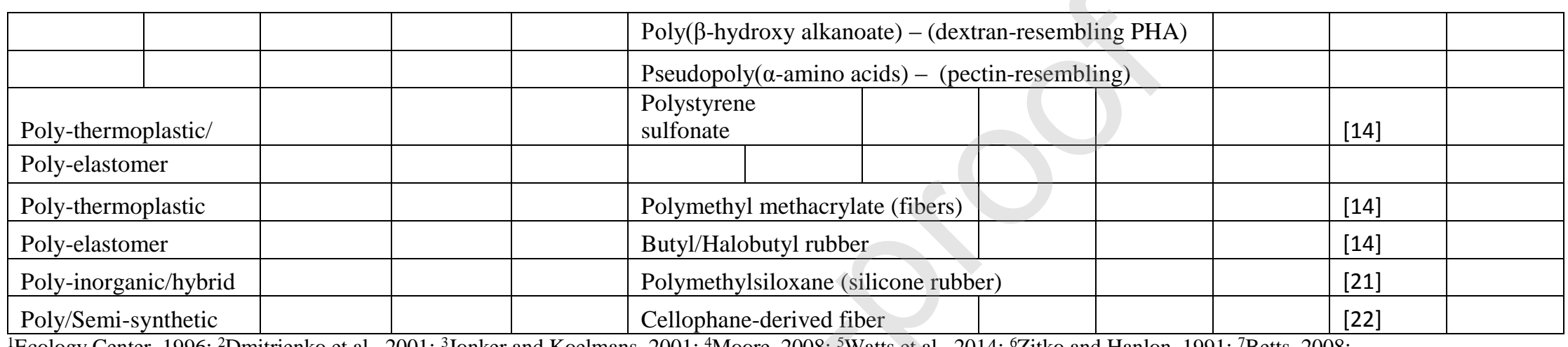

${ }^{1}$ Ecology Center, 1996; ${ }^{2}$ Dmitrienko et al., 2001; ${ }^{3}$ Jonker and Koelmans, 2001; ${ }^{4}$ Moore, 2008; ${ }^{5}$ Watts et al., 2014; ${ }^{6}$ Zitko and Hanlon, $1991 ;{ }^{7}$ Betts, 2008;

${ }^{8}$ de Dardel and Arden, 2008; ${ }^{9}$ Rochman et al.,2013; ${ }^{10}$ Murphy, 2018; ${ }^{11}$ Hesler et al., 2019; ${ }^{12}$ Paget et al., 2015; ${ }^{13}$ Lithner et al., 2009; ${ }^{14}$ Ballent et al., 2016;

${ }^{15}$ Krzan et al., 2006; ${ }^{16}$ Hardy, 1999; ${ }^{17}$ Norris et al., 1973; ${ }^{18}$ Güven et al., 2017; ${ }^{19}$ Besselinget al., 2015; ${ }^{20}$ Garnett et al., $2012 ;{ }^{21}$ Rusina et al., $2010 ;{ }^{22}$ Jabeen et al., 2017. 


\section{Table 2}

Bioaccumulation of microplastics in aquatic organisms and toxic effects of hydrophobic organic compounds in humans.

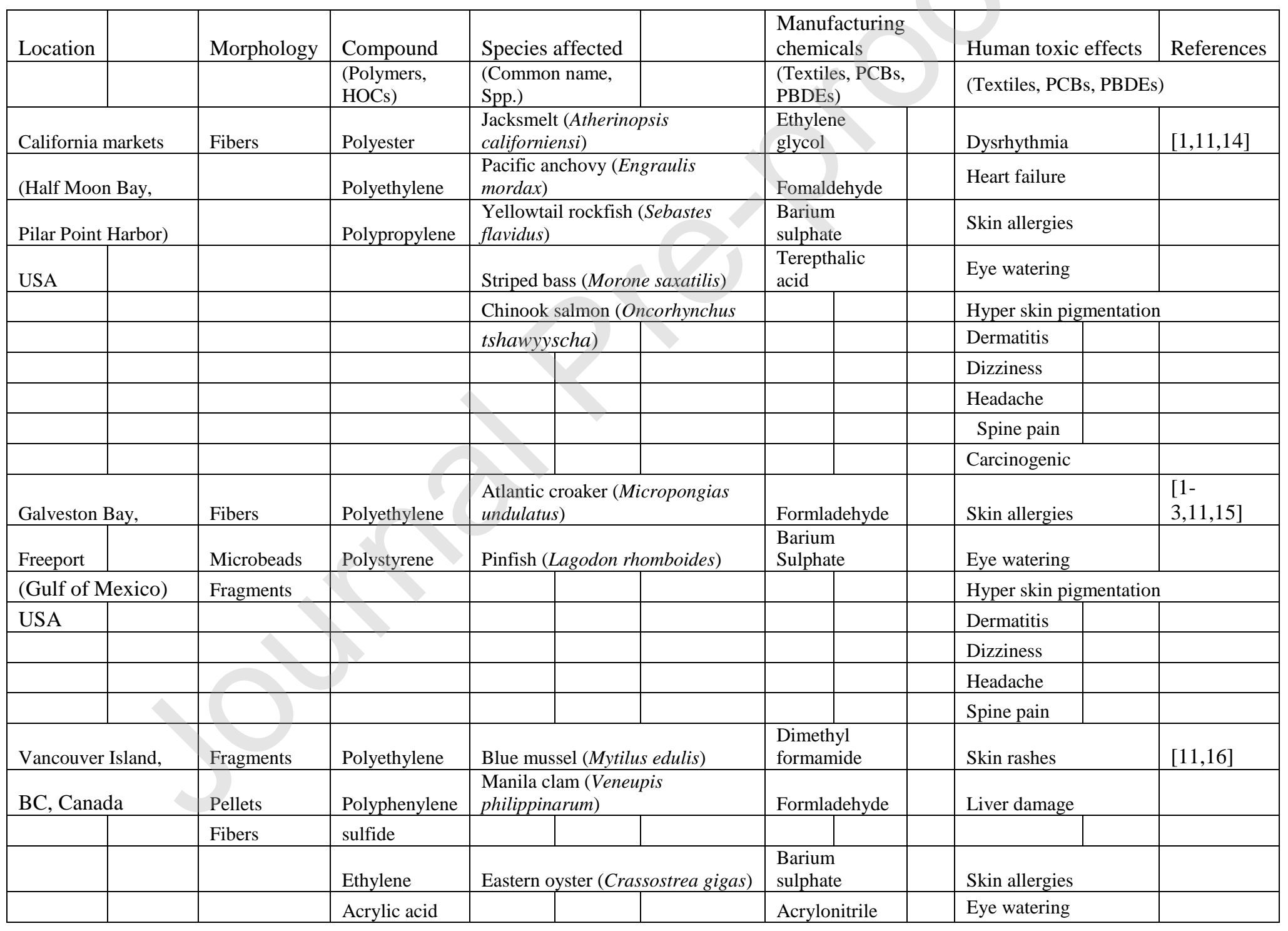




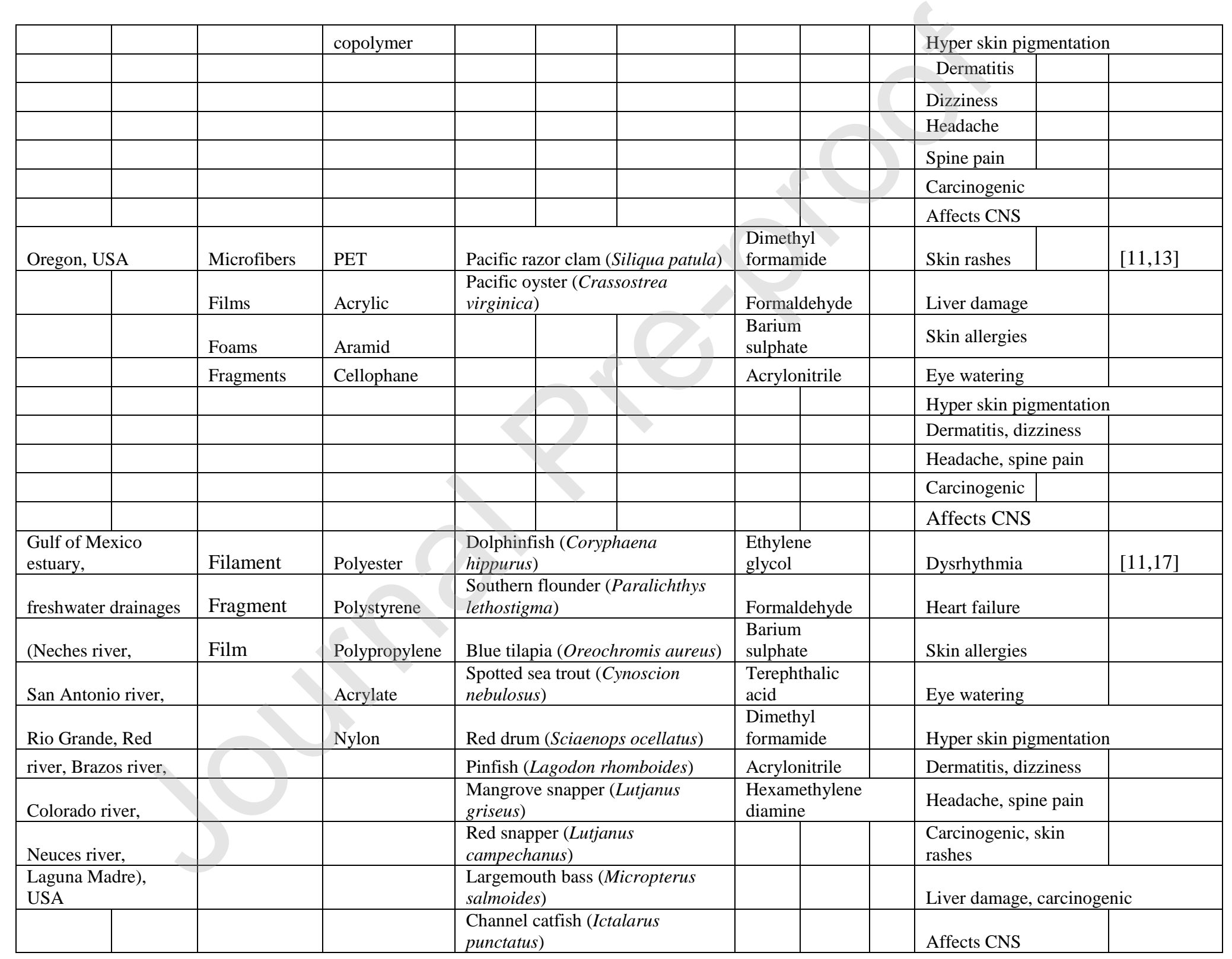




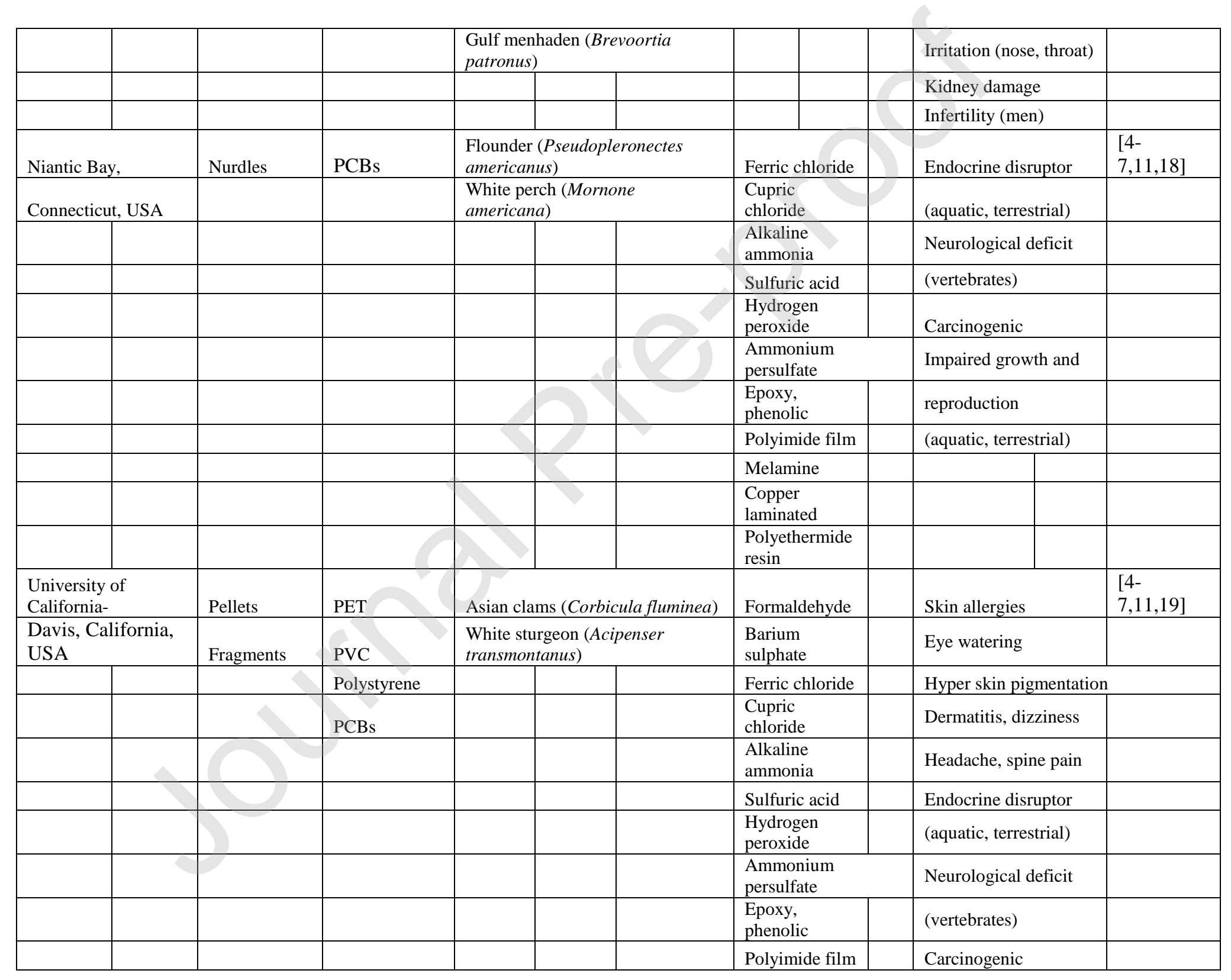




\begin{tabular}{|c|c|c|c|c|c|c|}
\hline & & & & Melamine & Impaired growth and & \\
\hline & & & & $\begin{array}{l}\text { Copper } \\
\text { laminated }\end{array}$ & reproduction & \\
\hline & & & & $\begin{array}{l}\text { Polyethermide } \\
\text { resin }\end{array}$ & (aquatic, terrestrial) & \\
\hline Plym estuary, & Fragments & PVC & Lugworm (Arenicola marina) & $\begin{array}{l}\text { PBDE } \\
\text { congener }\end{array}$ & Bioaccumulation & {$[8-11,20]$} \\
\hline United Kingdom & & Nonylphenol & & $\begin{array}{l}\text { mixture (tetra-, } \\
\text { penta-, }\end{array}$ & (serum, breast milk) & \\
\hline & & Phenanthrene & & $\begin{array}{l}\text { hepta-, octa-, } \\
\text { deca-) }\end{array}$ & Developmental & \\
\hline & & $\begin{array}{l}\text { PBDE (BDE- } \\
47)\end{array}$ & & & neurotoxicity and & \\
\hline & & Triclosan & 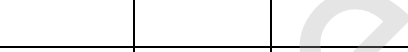 & 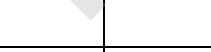 & thyroid hormone & \\
\hline & & & $(x$ & & suppression & \\
\hline & & & (es & & (rodents) & \\
\hline
\end{tabular}

${ }^{1}$ Lushe et al., 2013; ${ }^{2}$ Munno, 2017; ${ }^{3}$ Gaspar et al., 2018; ${ }^{4}$ Gong, $2017 ;{ }^{5}$ Spitz, $1985 ;{ }^{6.7}$ Rahman et al., 2011, 2020; ${ }^{8}$ Siddiqi et al., 2003; ${ }^{9}$ Pettigrew, $1993 ;{ }^{10}$ Lassen et al., 1999 ;

${ }^{11}$ Darnerud et al., 2001; ${ }^{12}$ Singh and Bhalla, 2017; ${ }^{13}$ Baechler et al., 2020; ${ }^{14}$ Rochman et al., 2015; ${ }^{15}$ Peters et al., 2017; ${ }^{16}$ Murphy, 2018; ${ }^{17}$ Phillips and Bonner, 2015;

${ }^{18}$ Carpenter et al., 1972; ${ }^{19}$ Rochman et al., 2017; ${ }^{20}$ Browne et al., 2013.

CNS, central nervous system; PET, polyethylene terephthalate; PCBs, polychlorinated biphenyls; PVC, polyvinyl chloride; PBDEs, polybrominated diphenyl ethers;

BDEs, brominated diphenyl ethers. 